Effects of Diaphragm Strengthening on Severity of Pain and Functional Parameters in Patients with Chronic Nonspecific Low Back Pain

\author{
$\mathrm{PhD}$ Thesis
}

Regina Finta

Szeged, 2019 


\title{
Effects of Diaphragm Strengthening on Severity of Pain and Functional Parameters in Patients with Chronic Nonspecific Low Back Pain
}

\author{
Ph.D. Thesis \\ REGINA FINTA \\ Supervisors: \\ Tamás Bender M.D., Ph.D., D.Sc. \\ Department of Orthopaedics, Faculty of Medicine, \\ University of Szeged, Hungary \\ Edit Nagy Ph.D \\ Department of Physiotherapy, Faculty of Health Sciences, \\ University of Szeged, Hungary \\ Director of Doctoral School of Clinical Medicine: \\ Lajos Kemény, M.D., Ph.D., D.Sc.
}

Szeged, 2019 


\section{LIST OF PUBLICATIONS}

included in the dissertation

I. $\quad$ Finta R; Bender T: A diaphragma müködésében bekövetkező változások és a derékfájdalom összefüggései, fizioterápiás kezelési lehetőségek. Balneológia, Gyógyfürdőügy, Gyógyidegenforgalom. 2017;36:13-21.

II. Finta R; Polyák I; Bender T; Nagy E: Effects of exercise therapy on postural stability, multifidus thickness, and pain intensity in patients with chronic low-back pain. Developments in Health Sciences. 2019bb;1-7.7 p.

III. Finta R; Nagy E; Bender T: The effect of diaphragm training on lumbar stabilizer muscles: a new concept for improving segmental stability in the case of low back pain. Journal of Pain Research.2018;3031-3045. IF: 2.236

IV. Finta R; Boda K; Nagy E; Bender T: Does the efficiency of inspiration have an influence on the stability limits of the trunk in patients with chronic low back pain? 2019. Manuscript submitted for publication. 


\section{LIST OF PUBLICATIONS \\ related to the subject of the dissertation}

Finta R; Nagy K; Bender T; Nagy E (in press): Izomfáradások hatásának vizsgálata; különbségek és hasonlóságok krónikus nemspecifikus derékfájdalommal küzdö és panaszmentes alanyok összehasonlításában -pilot study. Fizioterápia. 2019.

Finta R; Bender T: Törzsstabilizációs tréning másképp - vajon tudunk-e hatni a diaphragma erősítésén keresztül a derékfájdalomra? (előzetes mérési eredményeink ismertetése). In: Koncz, István; Szova, Ilona (szerk.) A 15 éves PEME XV. PhD - Konferenciájának előadásai: Budapest, Magyarország: Professzorok az Európai Magyarországért Egyesület, 2017;201-209.

\section{LIST OF PUBLICATIONS not related to the subject of the dissertation}

Nagy E; Posa G; Finta R; Szilágyi L; Sziver E: Perceptual Aspects of Postural Control: Does Pure Proprioceptive Training Exist? Perceptual and motor skills. 2018; 581-595. IF: 1.049

Kalmár Á; Pósa G; Finta R; Nagy E; Szilágyi L: Pulzushullám terjedési sebesség mérése egyetemisták körében. Nővér. 2018;31:1-9.

\section{PRESENTATIONS}

\section{related to the subject of the dissertation}

Finta R; Pál A: Testsúlycsökkentő intervall tréning hatása a derékfájdalomra és a funkcionális kapacitásra. Magyar Gerincgyógyászati Társaság Tudományos Ülése 2019. február 22-23.

Finta R; Kovács D; Gugánovity Zs: A derékfájdalom gyógytornakezelésének hatása az egyensúlyi paraméterekre.Előadás, A PEME (Professzorok az Európai Magyarországért Egyesület) XVI. PhD konferenciája, 2018. április 11., Budapest

Finta, R; Gugánovity Zs; Kovács D; Nagy E: A musculus multifidus lumborum, mint a derékfájdalom változásának indikátora. In: "Tudomány a fizioterápiában" : I. Predoktori Konferencia Absztrakt füzet (2018) pp. 3-3. , 1 p.

Finta R; Gugánovity Zs; Kovács D; Nagy E: A fájdalom és a poszturális funkció összefüggései: A M. Multifidus Lumborum aktivitás változásai. Előadás, 
Doktoranduszok Országos Szövetsége, Tavaszi Szél Konferencia, 2018. 05. 0406., Györ

Finta R; Bender $\mathrm{T}$ : Can strengthening of the diaphragm improve the lumbarstabilizer system? In: Bódog, Ferenc (szerk.) VII. Interdiszciplináris Doktorandusz Konferencia 2018 absztraktkötet -7th Interdisciplinary Doctoral Conference 2018 book of abstracts. Pécs, Magyarország: Pécsi Tudományegyetem Doktorandusz Önkormányzat, (2018) pp. 106-106. , 1 p.

Finta R; Bender T: Belégzőizom-erősítő tréning hatása a derékfájdalomra: $(\mathrm{PhD}$ téma bemutatása). Balneológia, Gyógyfürdőügy, Gyógyidegenforgalom. 2017;36:74-75.

Finta R; Katona P; Pósa G; Szilágyi L; Nagy E: Védekezés, vagy stabilizálás? Az izommüködés változásai derékfájdalom esetén. Poszter, PEME XV. PhD Konferencia, Professzorok az Európai Magyarországért Egyesület, Budapest, 2017. november 08 .

Finta R; Katona P; Szilágyi L; Pósa G; Nagy E: A poszturális kontroll változásai derékfájdalom esetén: a m. latissimus dorsi aktivitásváltozása. In: Bódog, Ferenc; Csiszár, Beáta; Hegyi, Dávid; Pónusz, Róbert (szerk.) DKK17-Doktoranduszok a Klinikai Kutatásokban absztraktkötet. Pécs, Magyarország : Pécsi Tudományegyetem Doktorandusz Önkormányzat, (2017) pp. 74-74. , 1 p.

Finta R; Gittinger A; Polyák I: Musculoskeletális diagnosztikus ultrahang: krónikus, aszimmetrikus derékfájdalom hatása a törzsstabilizátorokra. In: Bódog, Ferenc; Csiszár, Beáta; Hegyi, Dávid; Pónusz, Róbert (szerk.) DKK17Doktoranduszok a Klinikai Kutatásokban absztraktkötet. Pécs, Magyarország: Pécsi Tudományegyetem Doktorandusz Önkormányzat, (2017) pp. 30-30. 1 p.

Finta R; Katona P; Mihalik R: EMG analysis of hip and trunk muscles among people with chronic low back pain pp. 103-103. In: Laczkó, József (szerk.) Progress in Motor Control X. : Program and Abstracts Budapest, Magyarország : Hungarian Society of Sport Science, (2015) p. 176

Boda K, Finta R: Ismételt mérések figyelembe vétele a statisztikai elemzés során. In: Bari Ferenc, Rárosi Ferenc (szerk) A XXXI. Neumann Kollokvium konferencia-kiadványa. XXIX. Neumann Kollokvium Orvosi Informatika. Szeged, 2018. november 30 - december 1. 
Gábor K; Farkas K: A légzőtorna és az egyensúlyfejlesztő torna hatása fiatal derékfájdalommal küzdők körében. OTDK 2019. III. helyezés. Témavezető: Finta R.. Orvosképzés A graduális és posztgraduális képzés folyóirata 2019. XCI. V. évfolyam, 2. Szám. Országos Tudományos Diákköri Konferencia, Orvos- és Egészségtudományi Szekció.

Nagy K: A törzsstabilizátorok fáradásának vizsgálata derékfájdalommal küzdő és panaszmentes egyéneken. OTDK 2019. Témavezető: Finta R. Orvosképzés A graduális és posztgraduális képzés folyóirata 2019. XCI. V. évfolyam, 2. Szám. Országos Tudományos Diákköri Konferencia, Orvos- és Egészségtudományi Szekció.

\section{PRESENTATIONS not related to the subject of the dissertation}

Finta R; Albertné Koncsek K; Szilágyi L; Aranyné Molnár T; Pósa G: Egyensúlyi állapotfelmérés inaktív idősek körében. Idősgyógyászat. 2016;1:103-103.

Szilágyi, L; Tóth, L; Finta R; Pósa G; Gyuris L; Nagy E: Az SMR henger hatása az érrendszerre. Sportorvosi Szemle. 2018;59:45-45.

Szilágyi L; Tóth L; Pósa G; Finta R; Koncsek K; Nagy E: Acute Effects of SelfMyofascial Release Technique on Arterial Stiffness. In: Bódog, Ferenc (szerk.) VII. Interdiszciplináris Doktorandusz Konferencia 2018 absztraktkötet -7th Interdisciplinary Doctoral Conference 2018 book of abstracts. Pécs, Magyarország: Pécsi Tudományegyetem Doktorandusz Önkormányzat, (2018) pp. 110-110. 1 p.

Szilágyi, L; Tóth L; Finta R; Pósa G; Gyuris L; Nagy E: Az SMR henger hatása az artériás stiffness paraméterekre. In: "Tudomány a fizioterápiában": I. Predoktori Konferencia Absztrakt füzet. (2018) pp. 9-9. , 1 p.

Aranyné Molnár T; Koncsek K; Pósa G; Finta R; Szilágyi L; Surányi A; Fekete $\mathrm{Z}$; Süli N: Az időskori inkontinencia újszerü mozgásterápiás kezelése: Esetismertetés. (2017) Előadás, A Magyar Gyógytornász-Fizioterapeuták Társasága XI. Kongresszusa, 2017. október 11-14, Győr.

Koncsek K; Aszódi F; Pósa G; Aranyné Molnár T; Szilágyi L; Finta R; Nagy E: Teljes testes elektromos izomstimuláció (WB EMS) - Új lehetőség a funkcionális fittség elérésben szenioroknál?: Esettanulmány. Előadás, A Magyar Gyógytornász-Fizioterapeuták Társasága XI. Kongresszusa, 2017. október 12-14, Győr, 
Posa G; Roka E; Sziver E; Finta R; Szilágyi L; Koncsek K; Nagy E: Osteoporosis and the Role of Physical Therapy in the Different Domains. Journal of Osteoporosis and Physical Activity. 2017; 5:190

Aranyné, Molnár T; Koncsek K; Pósa G; Finta R; Szilágyi L; Surányi A; Fekete $\mathrm{Z}$; Süli N: Az időskori inkontinencia újszerü mozgásterápiás kezelése Esetismertetés. Előadás, 50 Éves Magyar Gerontológiai és Geriátriai Társaság XXXIX. Kongresszusa, 2016. 09. 29-10.01.

Pósa G; Koncsek K; Finta R; Aranyné Molnár T; Szilágyi L; Süli N: Az időskori törések megelőzése. Előadás, Magyar Traumatológus Társaság Kongresszusa, Budapest, 2016. szeptember 1-3.

Aranyné Molnár T; Koncsek K; Pósa, G; Finta R; Szilágyi L; Surányi A; Fekete Z; Süli N: Az időskori inkontinencia újszerü mozgásterápiás kezelése Esetismertetés. Idősgyógyászat. 2016;1:98-98.

Koncsek K; Pósa G; Szilágyi L; Aranyné Molnár T; Finta R; Barnai M: 60 év feletti korosztály funkcionális fittségi állapota. Objektív és szubjektív tapasztalatok -előtanulmány. Idősgyógyászat. 2016;1:104-105.

Koncsek K.; Pósa G; Aranyné Molnár T; Szilágyi L; Finta R: Whole body electric muscle stimulation (WB EMS) - A new way to the functional fitness in seniors? Case study. European Journal of Integrative Medicine. 2016; 8:65

Szilágyi L; Koncsek K; Pósa G; Aranyné Molnár T; Finta R: Pulzushullám terjedési sebesség mérése idősödő populációban, összefüggések a testösszetétellel - előtanulmány. Idősgyógyászat. 2016;1:112-112. 


\section{Table of Contents}

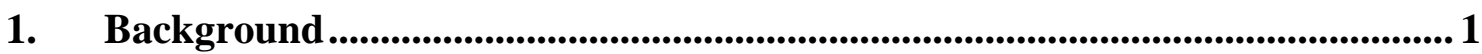

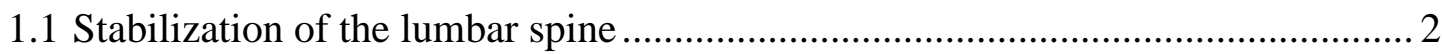

1.2 The role of the diaphragm in stabilization........................................................ 3

1.3 Issues of proprioception in low back pain ....................................................... 4

1.4 Evidences which support the efficiency of inspiratory muscle training ................ 5

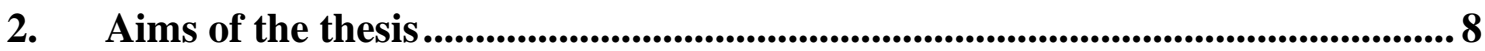

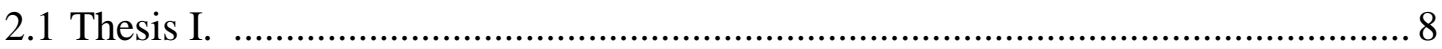

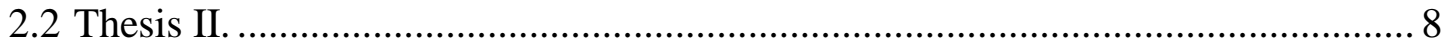

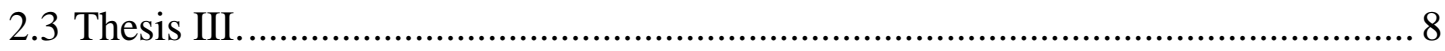

3. Materials and methods...................................................................................................... 9

3.1 Evaluation the effects of a conventional training program................................ 9

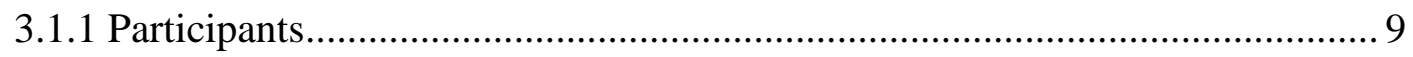

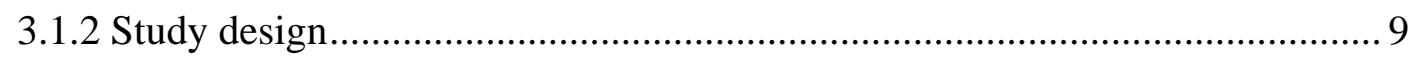

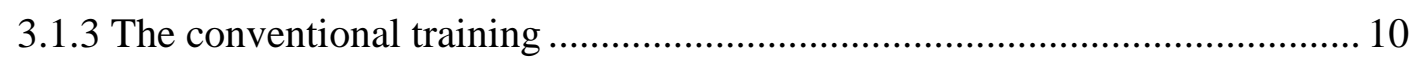

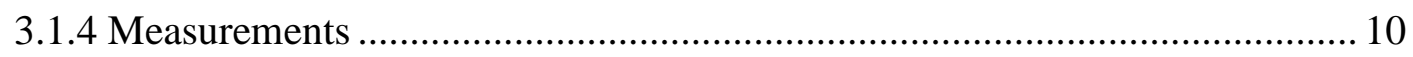

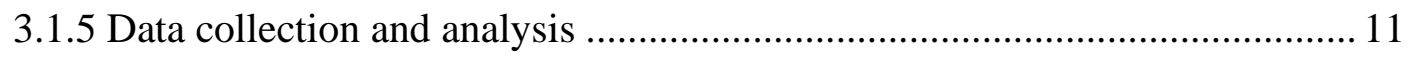

3.2 Evaluation the effects of a diaphragm strengthening training program .............. 12

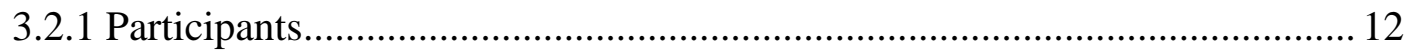

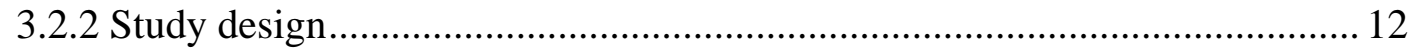

3.2.3 The conventional and the diaphragm strengthening training protocol .......... 14

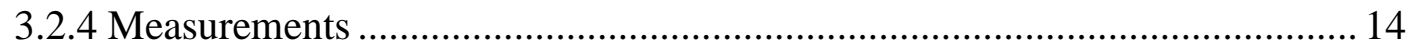

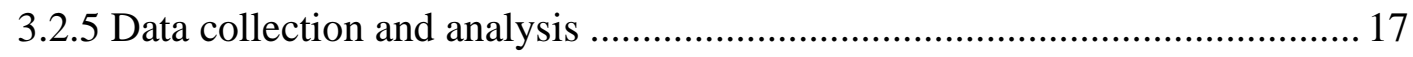

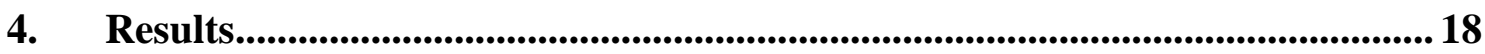

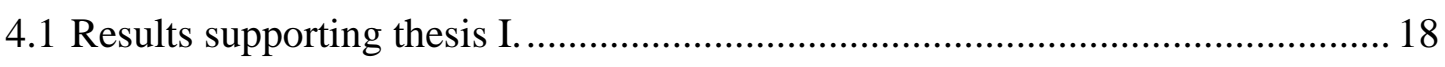

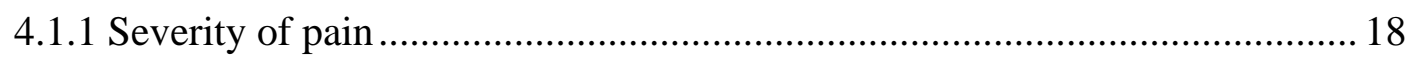

4.1.2 The thickness of lumbar multifidus muscle ............................................... 18 


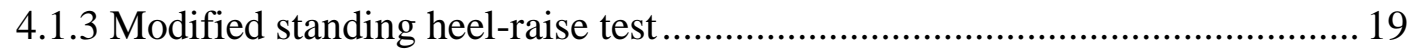

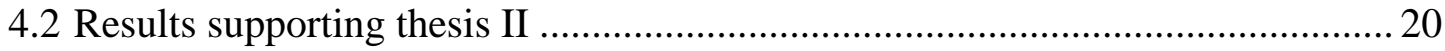

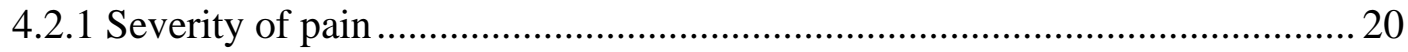

4.2.2 The thickness of the stabilizer muscles....................................................... 20

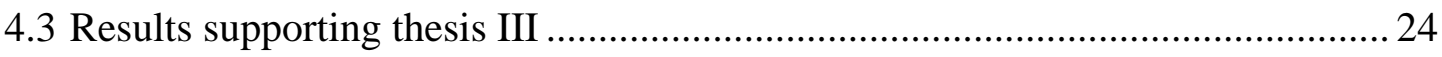

4.3.1 Chest Excursion ............................................................................ 24

4.3.2 Maximal Inspiratory Pressure (MIP) ................................................... 24

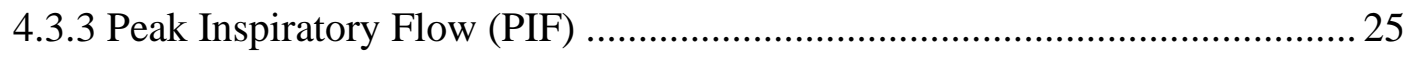

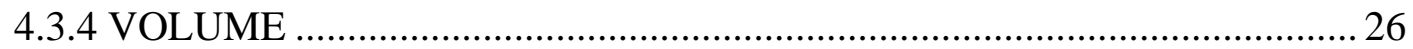

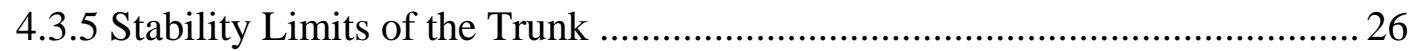

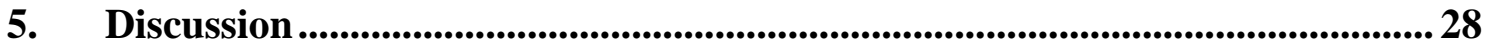

5.1 Effects of the conventional exercises alone ....................................................... 28

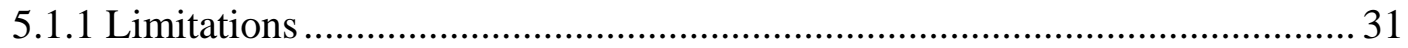

5.2 Effects of the conventional exercises completed with diaphragm training ...........31

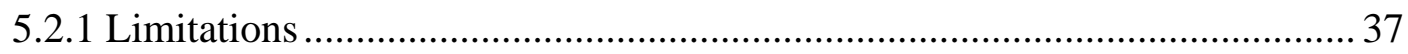

6. Conclusion and new results ........................................................................................39

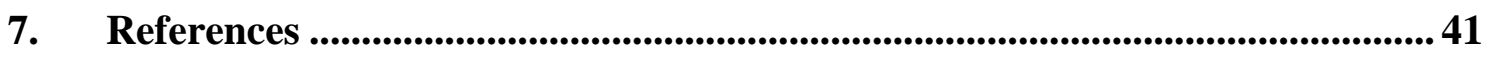

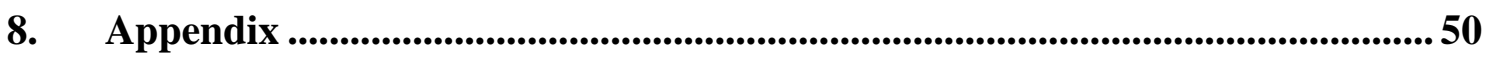

8.1 Supplementary materials of measurements and training sections .......................50

8.2 Supplementary materials of the results section .............................................. 52 


\section{LIST OFABBREVIATIONS}

LBP: $\quad$ low back pain

ROM: $\quad$ range of motion

LOS: limits of stability

mFRT: modified Functional Reach Test

mLRT: $\quad$ modified Lateral Reach Test

MIP: maximal inspiratory pressure

PIF: peak inspiratory flow

VOLUME: average amount of inhaled air

SD: $\quad$ standard deviation

VAS: visual analogue scale

DT: diaphragm training

C: $\quad$ control

BMI: $\quad$ body mass index

r: relatively

LR: $\quad$ left-sided, relaxed

LC: $\quad$ left-sided, contracted

RR: $\quad$ right-sided, relaxed

RC: $\quad$ right-sided, contracted

SE: $\quad$ standard error

COP: $\quad$ center of pressure 


\section{Background}

Low back pain (LBP) is a high burden disease ${ }^{1}$, which affects many people from children to the elderly. ${ }^{2}$ Based on the etiology chronic low back pain cases can be divided into two subcategories: specific and nonspecific low back pain. In specific LBP the origin of the pain is identifiable and the detected patology explains the symptoms. When the specific reason is not known nonspecific LBP is the applicable designation. More than $90 \%$ of the lumbago cases are mechanical issues, nonmechanical spinal conditions and visceral diseases are relatively rare. ${ }^{3}$ The term 'mechanical cause' usually used to describe an anatomical or functional abnormality without an underlying malignant, neoplastic, or inflammatory disease. Approximately $2 \%$ of cases of mechanical LBP are caused by spondylolysis, diskogenic origin, and presumed instability. ${ }^{3}$ In most cases, nonspecific LBP challenges the clinicians because imaging studies are basically not able to visualize the specific cause, which leads to both diagnostic and management dilemmas. ${ }^{4}$ Therefore, clinicians are under the necessity of treating the 'signs and symptoms' without considering the underlying cause or mechanism of the pain. ${ }^{4}$ Nonspecific chronic LBP is a real cause of concern and requires new and innovative management strategies, which take under consideration that the number of nonspecific LBP cases has been increasing dramatically. ${ }^{5}$ The mechanism of the developing alterations in the musculoskeletal and motor systems in lumbar pain has not been fully clarified yet; however, the postulated reason for nonspecific LBP is the segmental instability of the lumbar spine. ${ }^{6}$

\begin{tabular}{|c|c|c|}
\hline Mechanical LBP (97\%) & Nonmechanical LBP (1\%) & Visceral disease (2\%) \\
\hline lumbar strain -nonspecific (70\%) & neoplasia (0.7\%) & $\begin{array}{l}\text { disease of pelvic } \\
\text { organs }\end{array}$ \\
\hline degenerative process (10\%) & infection $(0.01 \%)$ & renal disease \\
\hline herniated disk (4\%) & inflammatory arthritis (0.3\%) & aortic aneuryzm \\
\hline spinal stenosis $(3 \%)$ & $\begin{array}{l}\text { Scheuermann's disease } \\
(<0.01 \%)\end{array}$ & $\begin{array}{l}\text { gastrointestinal } \\
\text { disease }\end{array}$ \\
\hline osteoporotic fracture (4\%) & $\begin{array}{l}\text { Paget's disease of bone } \\
(<0.01 \%)\end{array}$ & \\
\hline spondylolisthesis (2\%) & & \\
\hline $\begin{array}{l}\text { traumatic fracture, congenital } \\
\text { disease, etc. }(<1 \%)\end{array}$ & & \\
\hline
\end{tabular}

Table 1: Etiology-based subdivision of the most common LBP cases. ${ }^{3}$ 


\subsection{Stabilization of the lumbar spine}

The concept of segmental instability has not yet been proven in vivo, experiments were performed in vitro on cadaveric lumbar spines. ${ }^{6}$ Several researchers have tried to define segmental spinal instability but there is no accurate definition for the subtle forms of instability which are present when nonspecific low back pain occurs. This subtle instability may not be detected by radiological techniques or physical examination. According to Panjabi's 'neutral zone concept', the stability of the lumbar spine is maintained by the synergism of three subsystems: the neural, passive and active subsystem. Based on their theoretical findings, the total range of motion (ROM) of a spinal motion segment may be divided into two zones: a neutral and an elastic one. The neutral zone is the initial part of the total ROM and spinal motion is produced against minimal internal resistance in this zone. The elastic zone is the portion nearer to the endrange of movement that is produced against significant internal resistance. Increased segmental laxity occurs when the size of the neutral zone increases. The expansion of the neutral zone may occur as a result of a decrease in the capacity of the stabilizing system of the spine. Therefore, the increased size of the neutral zone is a better indicator of lumbar instability than the increased total ROM of the lumbar segment. Based on this theory, segmental instability may be defined as a decrease in the capacity of the stabilizing system of the spine to maintain the spinal neutral zones within physiological limits. ${ }^{6}$ The passive subsystem contains the spine and parts of the spinal joints; the neural subsystem receives information from the structures of the passive and active subsystems and it stabilizes the lumbar spine by controlling the function of the active subsystem namely the muscles. ${ }^{7}$ The neural and active subsystems are primarily responsible for spinal stability in the neutral zone. ${ }^{6}$ The members of the active subsystem can be divided into two groups: global and local stabilizer muscles. The global stabilizer muscles play an important role in performing the movements of the trunk and the hips, while the unique function of the local stabilizer muscles is the stabilization of the segments in relation to each other. ${ }^{8}$ Generally local stabilizers include all the deep layer muscles such as lumbar multifidus, transversus abdominis, pelvic floor muscles and diaphragm. ${ }^{9}$ The stabilizing function of these deep muscles can be realized in a variety of ways. Lumbar multifidus has an important role in the segmental control mainly during lifting and rotational movements. ${ }^{6}$ Transversus abdominis muscle attaches to the thoracolumbar fascia, therefore it is capable of increasing the stiffness of the lumbar spine indirectly. ${ }^{10}$ The pelvic floor muscles and 
diaphragm are in synergism with transversus abdominis and they are responsible for maintaining and increasing intra-abdominal pressure during several postural tasks. ${ }^{11}$ Hodges and co-workers presumed in a previous study that a possible explanation for the mechanism of the stabilizing function of the diaphragm and pelvic floor muscles is the following: the activation of transversus abdominis prior to the initiation of an upper limb movement results in the displacement of the abdominal contents, hence the consequential contraction of the diaphragm and pelvic floor muscles is necessary to restrain the shift of these abdominal structures. In their research they assessed the activation of the diaphragm and transversus abdominis muscle during repetitive arm flexions in standing position. Contrary to their hypothesis they found that the activation of diaphragm occurs prior to an arm movement and happens simultaneously with the activation of transversus abdominis. ${ }^{12}$ The exact role of diaphragm in trunk stabilization has been under investigation for more than 50 years but the accurate mechanism still remains poorly understood. ${ }^{13}$ There have been several types of research which investigated the functioning of trunk stabilizer muscles during upper limb movement in standing position. ${ }^{14,15,16,17}$ However, there have been few research considering the sitting position. ${ }^{17,12}$

\subsection{The role of the diaphragm in stabilization}

The diaphragm muscle is located inside the trunk as a membrane between the abdomen and the chest, and it is an essential muscle in breathing. Diaphragm is a respiratory muscle with postural function, and the deep abdominal muscles are postural muscles with respiratory function. ${ }^{18}$ The synergistic functioning of the abdominal muscles and the diaphragm is needed to perform normal postural stability and proper intraabdominal pressure, as in normal breathing. ${ }^{18}$ During normal breathing, the abdominal muscles are contracted, and the centrum tendinous of the diaphragm, which is supported from below, and the counter pressure of the abdominal muscles actually lift the lower ribs thus widening the thorax. Hence, if a subject relaxes the abdominal muscles, the abdomen moves during breathing and the chest remains immobile. In a vertical position, when the postural stability is challenged more, widening of the thorax should be more dominant than the abdominal breathing because of the necessarily enhanced intraabdominal pressure, which is needed for maintaining the stability of the lumbar spine ${ }^{18}$. The intraabdominal pressure can be increased during a postural task by breath control, 
which controls the amount of the inspired volume. The increased abdominal pressure is correlated with increased lumbar stability. ${ }^{19}$ Therefore, if the respiratory or stabilizer function of the diaphragm or the other stabilizer muscles is deteriorated and the coordination between the function of the respiratory and postural muscular systems is inaccurate, segmental instability of the lumbar spine may occur. ${ }^{19}$ Therefore, there is a significant correlation between some respiratory disorders and low back pain; moreover, these respiratory diseases predispose the patient to the development of pain in the lumbar area. ${ }^{20}$ Hagins and Lamberg have shown in a study that people with chronic low back pain have different natural breath control from healthy individuals. Individuals with low back pain perform a weight lifting task with higher inspiratory vital capacity than painfree individuals, independently of height, weight, gender, and resting tidal volume. The breath control depends on the phase of the lifting procedure; individuals with lumbar pain inhale higher volume before the concrete lifting but exhale it faster than healthy individuals. However, their results also show that there is no difference in inspiratory vital capacity between people with low back pain people and healthy subjects at age 22. ${ }^{19}$ People with chronic low back pain have a higher diaphragm position, a smaller diaphragm excursion $^{21}$, and their diaphragm muscle is characterized by greater fatigability. ${ }^{22}$ Their respiratory output is deteriorated compared to healthy subjects. ${ }^{23}$ Former studies have shown that if a patient bends down to lift a weight, forces are generated at the lumbosacral area. ${ }^{18}$ During a postural task, the intraabdominal pressure needs to be increased to provide the needed stabilization of the lumbar spine. If someone bends down to lift a weight, the diaphragm is contracted as well as the muscles in the abdominal wall. ${ }^{18}$ Based on the aforementioned studies, the influence of the function of the diaphragm and the abdominal muscles on lumbar stability is evident. It is also proved that patients with low back pain have deteriorated functioning and structure of the stabilizer muscles. ${ }^{24}$

\subsection{Issues of proprioception in low back pain}

Based on previous studies, the pain of the lumbar area seems to affect proprioception negatively. ${ }^{25,26}$ Chronic LBP causes an increased presynaptic inhibition of muscle input, and it may be associated with diminishing proprioception in muscle spindles causing prolonged latency by the decrease in muscle spindle feedback and trunk muscle strength. ${ }^{27}$ Therefore, postural control is different in the healthy and low back pain populations. $^{28,29,30,27}$ Chronic LBP subjects have a greater postural sway in anterior- 
posterior and medial-lateral directions during quiet standing than healthy people. ${ }^{27,29}$ During prolonged standing, however, when the subjects were allowed to make voluntary movements, patients with chronic LBP swayed less than healthy subjects in both the anterior-posterior and medial-lateral directions. ${ }^{31}$ This kind of strategy may be related to the lack of mobility, and it may indicate decreased proprioception and may lead to a stiffened posture. ${ }^{31}$ According to a study, low back pain individuals prefer using the ankle strategy to maintain the vertical position of the body. ${ }^{28}$ In this research, low back pain individuals were involved in an inspiratory muscle training to improve their postural function. As an effect of the inspiratory muscle training, the postural control turned to a normal, multisegmental postural strategy in subjects with low back pain. ${ }^{28}$ The abovementioned studies assessed the postural strategy during standing, whereas several body parts (ankles, knees, hips, and trunk) contribute to the values of the measurements in standing position. ${ }^{32}$ Reach tests are frequently used tools to assess dynamic balance and indirectly measure the limits of stability (LOS) in the anterior-posterior and medial-lateral directions in standing. ${ }^{33}$ Since most of the studies have focused on the standing position in chronic LBP subjects to assess the stability limit, there is no study available assessing LOS in sitting position. However, there is a seated version of the reach tests, which is a viable screening tool of seated postural control ${ }^{34,35,36}$ with avoiding the ankle strategy. Sitting/modified functional (mFRT) and lateral reach tests (mLRT) are reliable measurements to quantify sitting balance and LOS. ${ }^{36}$ These sitting reach tests challenge balance beyond static sitting and simulate functional movements. ${ }^{36}$

\subsection{Evidences which support the efficiency of inspiratory muscle training}

$\mathrm{Ki}$ and co-workers measured the effect of forced breathing exercises on lumbar stability. They proved that forced breathing exercises may improve lumbar stability in case of low back pain ${ }^{37}$ but the role of breathing exercises in the background of the mechanism of improved lumbar stability was not clarified by this study. As it was mentioned before, LBP affects the lumbar proprioception which results in an altered postural control and poorer balance. In a recently published study the researchers proved that diaphragm and deep abdominal muscle exercise improves the walking ability and balance in stroke patients. Their training was conducted for 6 weeks and 5 days per week. In case of the intervention group, PowerBreathe inspiratory muscle trainer was used to improve the mobility, power, and endurance of diaphragm and bracing exercises were 
used to activate the local stabilizer muscles of the trunk. Significantly more improvement was found in the intervention group in walking and balance ability. ${ }^{38}$ Inspiratory training is effective in a wide spectrum of ages. Inspiratory muscle training is effective not only in young individuals but in older adults as well. In a recently published placebo controlled randomized study older adults were conducted in an unsupervised, home-based inspiratory muscle training program. Balance, physical performance and respiratory outcomes were assessed. Participants of the intervention group achieved significantly better values than the placebo control group. Interestingly, the anterior and posterior trunk muscles' endurance developed as well with the inspiratory exercises. Based on the results it can be stated, that a home-based inspiratory muscle strengthening training is an applicable method for improving balance, physical performance and respiratory functions. According to the authors, balancing ability improved owing to the strengthened diaphragm muscle, by that its phasic contractions assist in maintaining postural stability in unstable situations. ${ }^{39}$ Janssens and co-workers proved that the postural stability of the trunk can be improved by strengthening the diaphragm muscle and suggest that lumbar pain intensity may be decreased by diaphragm training. They strengthened the diaphragm with a POWERbreathe device which provides resistance to inhalation. Their training program lasted for 8 weeks and the displacement of the center of the pressure was assessed by using a force plate. Pain intensity was measured with the Oswestry Disability Index. They found that the 8-week-long intensive diaphragm training increased respiratory muscle strength, proprioceptive use changed in a positive way and the participants reported a decrease in low back pain severity. ${ }^{28}$ They presumed that their training program had an effect on the muscles other than diaphragm as well and may have improved the stabilization of the trunk. ${ }^{28}$ However, the changes which may have occurred as a result of the diaphragm strengthening training in the musculature and the mechanisms which provided the improvement of lumbar stabilization were not identified in their research.

Based on the aforementioned studies, we can see that there are evidences which prove that diaphragm training has additional benefits in the rehabilitation of LBP people. This type of training is a viable way to improve postural control, balance, physical outcomes and to decrease the intensity of lumbar pain. Indirectly, diaphragm training is effective in enhancing the lumbar stability, via improving the effectiveness of modulating the intraabdominal pressure. ${ }^{3938}$ Interestingly, this mechanism works vice-versa, thus stabilization exercises also have an effect on the diaphragm muscle. Dülger and co- 
workers compared the effects of stabilization exercises including motor control training (intervention group) with general exercises (strengthening the back-, abdominal-, and hip muscles) (control group). The patients participated in the treatment 3 days in a week for 10 weeks. Ultrasonography was used to measure the thickness of diaphragm muscle and lumbopelvic stability test (stabilizer Pressure Biofeedback Unit) was used to assess lumbar stability. As a result, it can be stated that stabilization exercises are significantly more effective on increasing diaphragm muscle thickness and lumbopelvic stability than general exercises. ${ }^{40}$ Their results conclude that stabilization exercises alone have an influence on the function of diaphragm and it is presumable that on the other stabilizer muscles' as well. 


\section{Aims of the thesis}

The importance of using non-pharmacological treatments, such as physical exercises, to reduce the intensity and possible negative consequences of low back pain is well-known. ${ }^{41}$ However, to date there has been no unitary exercise training program or any well-established complex solution to the problem and there is a huge gap between evidence and practice. ${ }^{41}$ Helping to improve functional capacity and decrease the severity of pain for those who are not able to perform the conventional exercises is also a critical issue in accordance of managing LBP patients. Previous studies specified the impact of several types of training on chronic LBP, but a diaphragm strengthening training has not been tested yet as a solution to it. By reviewing the literature, we can see that diaphragm training could have several benefits in the rehabilitation of chronic LBP, although there are certainly several other effects as well, which have not been proven yet. Moreover, the accurate reason of the effectivity of diaphragm strengthening in LBP cases and its role in this complex phenomenon is not understand to date.

\subsection{Thesis I.}

In our study we sought to investigate the effect of an 8-week conventional training program (strengthening of abdominal, back and hip muscles, and balance exercises) in patients with chronic nonspecific LBP on the thickness of lumbar multifidus muscle. Additionally, we intended to monitor the changes of postural stability in the different stages of pain.

\subsection{Thesis II.}

We intended to assess the effects of an 8-week diaphragm strengthening training on the severity of LBP and on thickness not only of the diaphragm but on that of other stabilizer muscles like transversus abdominis and lumbar multifidus muscle.

\subsection{Thesis III.}

We aimed to evaluate the effect of the diaphragm strengthening training on the parameters of the inhalation (chest excursion, maximal inspiratory pressure (MIP), peak inspiratory flow (PIF), and average amount of inhaled air (VOLUME)), and to assess whether the diaphragm training would improve the stability limits of the trunk in patients with nonspecific chronic LBP. 


\section{Materials and methods}

Altogether 72 participants were involved in the study. Twenty people (10 healthy and 10 LBP patients) of that was participated in the evaluation of the effects of a conventional training program and fifty-two LBP patients were involved in the evaluation of the effects of a diaphragm strengthening training program. All participants gave their written informed consent. The study is in compliance with the principles of the Declaration of Helsinki. The training sessions and the measurements were conducted in a gym which belongs to the Department of Physiotherapy, Faculty of Health Scienses, University of Szeged.

\subsection{Evaluation the effects of a conventional training program}

\subsubsection{Participants}

To evaluate the effects of a conventional training program (strengthening of abdominal, back and hip muscles, and balance exercises) altogether 20 subjects were recruited: 10 for group LBP and also 10 for control (C) group. The average age was 20.70 years (SD 1.49) in group LBP $(n=10)$ and 22.30 years (SD 1.06) in group $C(n=10)$. The inclusion criteria in the case of group LBP were chronic low back pain, the participants were required not to have any other treatment during the investigation, and they had to be able to get to the location of the training. The inclusion criterion in case of group $\mathrm{C}$ was no history of chronic low back pain. Exclusion criteria in case of both groups were balance problems of neurological cause, a malignant tumor, serious organ disease, a previous surgical intervention which affected the trunk or if the person was unable to cooperate.

\subsubsection{Study design}

Young adult participants were recruited from our university and they were divided into two groups: group $\mathrm{C}$ for asymptomatic individuals and group LBP for individuals with a history of chronic low back pain (at least 3 months duration of pain ${ }^{2}$ ). By the reason of the measuring process, only physiotherapy students were included in the study who have a more developed perception of movement and body awareness based on the characteristics of physiotherapy education. The members of group LBP participated in an 
8-week conventional training program. Contrary to group LBP, members of group C did not take part in any training during the 8-week period.

\subsubsection{The conventional training}

There were 2 training sessions per week (1 hour each). At the beginning of a session there was a warm-up section and at the end there was a cool-down section, both in a 10 minutes duration. The main part of the training contained mostly strengthening, stretching and mobilizing exercises on the muscles of the trunk and the hip. Static and dynamic exercises were applied with aid of tools (e.g. elastic bounds, dumbbells and heavy balls) and without tools. The training program was completed with balance exercises. Unstable training tools were used to improve their balance throughout static and dynamic exercises. Three physiotherapists ensured the correct implementation of the exercises.

\subsubsection{Measurements}

The measurements were conducted before and after the intervention period. The intensity of the pain was assessed by a Visual Analogue Scale (VAS) in $\mathrm{cm}^{42}$ VAS is a unidimensional measure of pain intensity, which has been widely used in diverse adult populations. ${ }^{43}$ It is a continuous scale comprised of a horizontal line $10 \mathrm{~cm}$ in length. The scale is anchored by 'no pain' (score of 0 ) and 'worst imaginable pain' (score of 10). A higher score indicates greater pain intensity. ${ }^{43}$ Test-retest reliability is good $(r=0.94$, $\mathrm{P}<0.001) .{ }^{43}$ VAS scores are shown to correlate highly with other pain measure scores $(\mathrm{r}=0.62-0.91)$; and they are sensitive to measuring changes in pain associated with treatment or time. ${ }^{43}$ For comparison of the pain intensity averages were calculated by group (mean $\pm \mathrm{SD}$ ). The thickness of lumbar multifidus muscle's belly was measured by B-mode ultrasonography on both sides of the trunk, using a Zonare Z.One Ultrasound System (Mountain View, CA, USA, 2013) in two different positions (prone and kneeling positions) and in two different states (relaxed and contracted states). The thickness of the muscle was measured by placing electronic calipers just inside the hyperechoic connective tissue layers. In the prone position (lying on the chest with the face down), during the measurements the curved transducer was used (frequency range between 6-2 $\mathrm{MHz}$ ) longitudinally along the spine with the mid-point over the L4 spinous process. It was moved laterally and angled slightly medially until the L4/5 zygapophyseal joint could 
be identified, and the muscle was assessed in a relaxed (calm lying) position and in a contracted state. ${ }^{44}$ For the contracted state, the students were asked to contract the muscles of the lumbar area without extra movement of the trunk. To reach a more efficient muscle contraction, tactile stimulation was implemented above the hypothesized area of the muscle (Figure 1). ${ }^{45}$ To examine the postural activity of lumbar multifidus muscle the thickness of the muscle's belly was measured in a kneeling position as well. In the kneeling position, the postural function of lumbar multifidus muscle is enhanced due to the vertical position. The participants were instructed to keep an erect posture. When the subjects held a quiet kneeling position it was defined as a relatively relaxed state and when we asked them for muscle contraction it was defined as a relatively contracted state. The same triggering design was applied in kneeling position as well to enhance the contraction besides the postural activity of the lumbar multifidus muscle. To ensure the same setting for ultrasonography, the skin surface was constantly marked, and the measurement was carried out by the same person with experience in ultrasonography. Test-retest reliability was tested by calculation of intra-class correlation and the reliability coefficient. Both the high interclass correlations (0.991-1) and the small repeatability coefficients (0.008-0.095) showed good reliability.

For testing the improvement of the lumbar stabilizer system, a modified standing heel-raise test was applied. The standing heel-raise test is commonly used to assess the function of plantar flexors, essential muscles for locomotion and postural tasks. ${ }^{46}$ The modified standing heel-raise test was performed on an unstable surface (dynair) to challenge more the postural function of the stabilizer muscles. The participants had to stand in the middle of the disc and raise their heels continuously within 30 s and the number of the raises was counted. The testing procedure was performed before and after the 8-week period.

\subsubsection{Data collection and analysis}

The data analysis and the calculations were executed with a Microsoft Office Excel, and a STATISTICA 13 software. The Shapiro-Wilk test was used as normality test. The level of significance was set at $\mathrm{p}<0.05$. To compare the changes which occurred within one group after the 8 weeks Wilcoxon Matched Pairs Test was used. Whereas, to compare the two groups, Mann-Whitney U test was used. 


\subsection{Evaluation the effects of a diaphragm strengthening training program}

\subsubsection{Participants}

A total of 52 people participated voluntarily in our study with a history of chronic nonspecific low back pain while two of them withdrew their participation. The inclusion criterion was low back pain lasting for at least 3 months. Participants were asked not to have any other treatment during the time of the training and they were required to be able to learn the usage of the diaphragm trainer and to be able to get to the location of the training. Exclusion criteria were the following: diagnosed specific causes of low back pain, balance problems of neurological origin, malignant tumors, serious organ diseases, respiratory diseases, previous surgical interventions affecting the trunk or the limbs and the subjects being uncooperative. The participants were asked to indicate immediately if an acute inflammatory disease occurred. Based on these exclusion criteria 3 subjects were excluded. All participants gave their written informed consent. The study is in compliance with the principles of the Declaration of Helsinki and was approved by the National Medical Research Council (identification number: 21416-2/2017/EKU). The trial is registered on www.clinicaltrials.gov (identification number: NCT03600207).

\subsubsection{Study design}

The study was a randomized controlled trial which took place from September to December 2017. The participants were divided (researcrandomzer.org) into two groups randomly: diaphragm training group (DT, $n=26)$ and control group $(\mathrm{C}, \mathrm{n}=21)$. The members of group $\mathrm{C}$ took part only in a conventional training, while the members of group DT performed the conventional training enhanced by diaphragm training. 


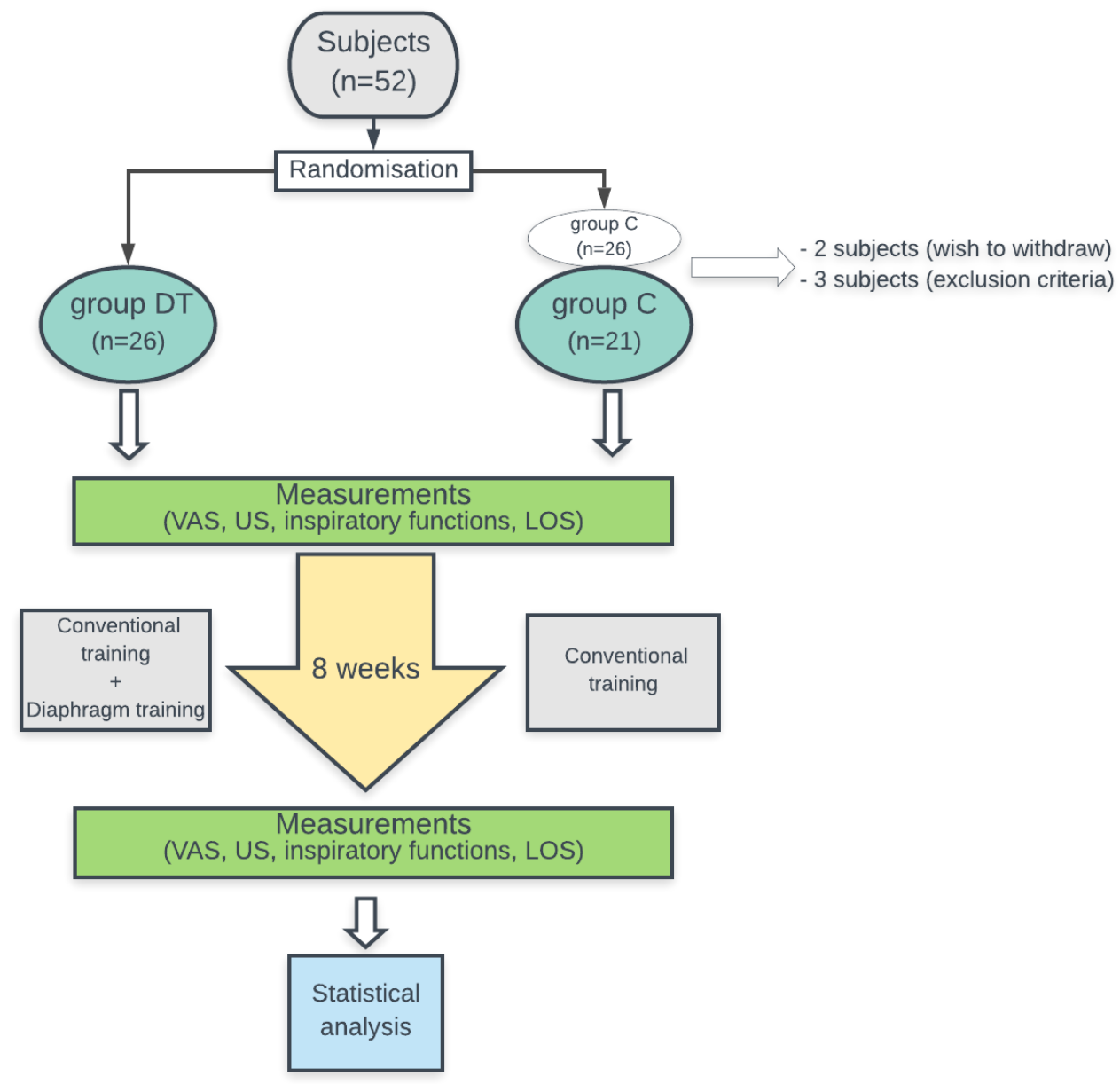

Figure 2: Flowchart of the study design.

(Abbreviations: C: control group, DT: diaphragm training group, VAS: Visual Analogue Scale,

US: ultrasonography, LOS: limits of stability)

There were no significant differences between the groups regarding age, BMI (Body Mass Index) and the duration of low back pain. The comparison of the main characteristics of the groups are summarized in Table 2.

\begin{tabular}{|c|c|c|c|c|c|c|}
\hline & \multicolumn{2}{|c|}{ C group } & \multicolumn{2}{|c|}{ DT group } & \multicolumn{2}{|c|}{ Mann-Whitney U Test } \\
\hline Characteristics & Mean & SD & Mean & SD & $P$-value & $\mathrm{Z}$ value \\
\hline Age (year) & 21.33 & 4.73 & 22.31 & 5.15 & 0.974395 & -0.032097 \\
\hline$B M I\left(\mathrm{~kg} / \mathrm{m}^{2}\right)$ & 22.14 & 3.67 & 24.88 & 6.02 & 0.06181 & 1.850929 \\
\hline \multicolumn{7}{|c|}{ Length of having low back pain (categories) } \\
\hline$>3$ months & \multicolumn{2}{|l|}{$4.76 \%$} & \multicolumn{2}{|l|}{$11.54 \%$} & \multirow{4}{*}{0.772678} & \multirow{4}{*}{-0.288873} \\
\hline$>6$ months & \multicolumn{2}{|l|}{$4.76 \%$} & \multicolumn{2}{|l|}{$7.69 \%$} & & \\
\hline$>1$ year & \multicolumn{2}{|l|}{$61.90 \%$} & \multicolumn{2}{|l|}{$50.00 \%$} & & \\
\hline$>2$ years & \multicolumn{2}{|l|}{$28.57 \%$} & \multicolumn{2}{|l|}{$30.77 \%$} & & \\
\hline
\end{tabular}

Table 2: The main characteristics of the groups.

(Abbreviations: C: control, DT: diaphragm training group) 


\subsubsection{The conventional and the diaphragm strengthening training protocol}

Both groups had an 8-week-long conventional training, which was done twice per week, with 60 minutes' duration (the details of the conventional training are included in the Appendix). The members of group C and DT participated in the same exercise program during the conventional training. Besides this, group DT used a POWERbreathe Medic Plus (POWERbreathe LTD) device (Figure 3) twice a day at home, 30 inhalations per occasion and with the speed of 15 inhalations/min in addition to the conventional training. The device was also used when trunk muscle strengthening exercises were performed during trainings. Using this device, members of group DT inhaled against resistance. The subjects were educated about the proper use of the POWERbreathe Medic Plus device during the first session. Before the training a baseline assessment was conducted in group DT: maximal inhalation pressure (MIP) was measured with a POWERbreathe KH2 (POWERbreathe LTD) device to determine the magnitude of resistance during training. The resistance was set individually to the value of $60 \%$ of the $\mathrm{MIP}^{28}$.

\subsubsection{Measurements}

The measurements were conducted before and after the 8-week training period.

Pain intensity was assessed with the VAS. ${ }^{42}$

The thickness of the stabilizer muscles' belly was measured with B-mode ultrasonography. Using a Zonare Z.One Ultrasound System (ZONARE Medical Systems, Inc. Mountain View, CA, USA; 2013) the thickness of transversus abdominis, lumbar multifidus and diaphragm muscles were recorded in two different positions: in lying and in sitting positions (Figure 4). The positions of the transducers can be further seen in Figure 5. All the muscles were measured in two different states: in a relaxed and in a contracted state. When a clear image of the measured muscles was seen, it was frozen on the screen and saved. The thickness of the muscles' belly was measured on the saved pictures. 3 pictures were taken of one muscle in one position and state. A total of 48 pictures were taken of each participant before the training and also 48 pictures after the training program. To ensure the same setting for ultrasonography, the skin surface was constantly marked, and the measurement was carried out by the same person with experience in ultrasonography. Test-retest reliability was tested by calculation of intra- 
class correlation and the reliability coefficient. Both the high interclass correlations (0.991-1) and the small repeatability coefficients (0.008-0.095) showed good reliability.

In case of transversus abdominis and diaphragm muscle, the subject was in a supine position with hips and knees flexed during the assessment (Figure 4a). Whereas in the case of the lumbar multifidus muscle the subject was in a prone position with flexed knees and the lumbar spine was positioned into flexion by a small pillow placed under the abdomen. Also, the knees were supported by a small pillow, providing approximately $30^{\circ}$ flexion (Figure $4 \mathrm{~b}$ ). All muscles were assessed in a sitting position as well: during holding the sitting posture (Figure 4c) and during a weightlifting task (Figure 4d). The subjects were sitting on a chair without back support with hips and knees flexed in $90^{\circ}$ and their feet were on the floor. The neutral position of the trunk was set, and the participants were asked to hold this position during the examination. The subjects were sitting calmly but the stabilizer muscles were active to maintain the vertical position, so the so-called relaxed state was just a relatively relaxed state (Figure 4c). To achieve a more contracted state of the stabilizer muscles in the sitting position a weightlifting activity was applied while holding the neutral position of the trunk. One dumbbell was used for the lifting procedure and it was held with both hands (Figure 4d). The participants had to lift the weight forward to the height of the shoulders with extended elbows and maintain this position until the ultrasonography was performed (about $2 \mathrm{~s}$ ) and repeat this maneuver as many times as was needed to assess the muscles. The patients were asked not to change the height of the lifting to ensure the same conditions. ${ }^{14}$ The weight to be lifted was chosen based on the subjective, perceived difficulty of the task: the subjects had to be able to lift it 13 times with short rests (about $5 \mathrm{~s}$ ) between them. 13 repetitions were determined because the first lifting was a testing procedure when we could correct the height of the lifting and the posture of the trunk if that was necessary. Then 3 pictures were taken of the assessed muscles ( 3 of transversus abdominis, 3 of the left- and 3 of the right-sided lumbar multifidus and 3 of diaphragm muscle). When a neutral trunk posture was held in sitting position it was defined as a relatively relaxed state whereas their lifting the weight in neutral trunk posture caused a relatively contracted state. Transversus abdominis muscle was assessed during tidal inhalation while diaphragm muscle during tidal exhalation to minimize the respiratory function of these muscles. The methodology of the ultrasound assessments is summarized in Table 3. 


\begin{tabular}{|c|c|c|c|c|c|}
\hline \multirow{8}{*}{ 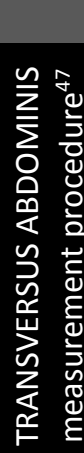 } & SPECIFICATION & \multicolumn{2}{|r|}{ LYING } & \multicolumn{2}{|c|}{ SITTING } \\
\hline & Contraction state & Relaxed & Contracted & r. relaxed & r. contracted \\
\hline & Position & $\begin{array}{l}\text { supine; lying } \\
\text { quietly }\end{array}$ & $\begin{array}{c}\text { supine; contraction of the } \\
\text { abdomen, without lifting the } \\
\text { head }\end{array}$ & $\begin{array}{l}\text { weight resting } \\
\text { on the thighs }\end{array}$ & weightlifting \\
\hline & Breathing state & tidal inhalation & forced exhalation & \multicolumn{2}{|c|}{ tidal inhalation } \\
\hline & Type of transducer & \multicolumn{4}{|c|}{ linear } \\
\hline & Transducer placement & \multicolumn{4}{|c|}{ right mid-axillary line between the pelvis and the costal margin } \\
\hline & Transducer bandwidth & \multicolumn{4}{|c|}{$10-5 \mathrm{MHz}$} \\
\hline & Caliper placing & \multicolumn{4}{|c|}{ inside the hyperechoic connective tissue layers } \\
\hline \multirow{6}{*}{ 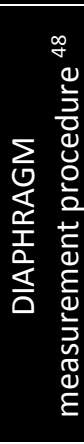 } & Position & \multicolumn{2}{|c|}{ supine; lying quietly } & $\begin{array}{l}\text { weight resting } \\
\text { on the thighs }\end{array}$ & weightlifting \\
\hline & Breathing state & tidal exhalation & $\begin{array}{l}\text { forced inhalation - } \\
\text { POWERbreathe } \mathrm{KH} 2\end{array}$ & tidal ext & Ialation \\
\hline & Type of transducer & \multicolumn{4}{|c|}{ linear } \\
\hline & Transducer placement & \multicolumn{4}{|c|}{$\begin{array}{c}\text { right anterior axillary line, eighth or ninth intercostal space without } \\
\text { encroaching on the lungs during inspiration }\end{array}$} \\
\hline & Transducer bandwidth & \multicolumn{4}{|c|}{$10-5 \mathrm{MHz}$} \\
\hline & Caliper placing & \multicolumn{4}{|c|}{$\begin{array}{c}\text { hypoechoic layer between the hyperechoic lines of pleural and peritoneal } \\
\text { fascia }\end{array}$} \\
\hline \multirow{6}{*}{ 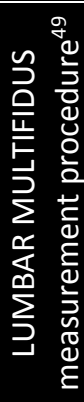 } & Position & $\begin{array}{l}\text { prone; lying } \\
\text { quietly }\end{array}$ & $\begin{array}{l}\text { prone; lifting the head and } \\
\text { the shoulders } 5 \mathrm{~cm} \text { high }\end{array}$ & $\begin{array}{l}\text { weight resting } \\
\text { on the thighs }\end{array}$ & weightlifting \\
\hline & Breathing state & \multicolumn{4}{|c|}{ irrelevant } \\
\hline & Type of transducer & \multicolumn{4}{|c|}{ curved } \\
\hline & Transducer placement & \multicolumn{4}{|c|}{$\begin{array}{l}\text { Left and right side of the lumbar area, longitudinally on the spine, moved } \\
\text { laterally so that a parasagittal image of multifidus could be taken }\end{array}$} \\
\hline & Transducer bandwidth & \multicolumn{4}{|c|}{$6-2 \mathrm{MHz}$} \\
\hline & Caliper placing & \multicolumn{4}{|c|}{$\begin{array}{c}\text { on the posterior-most portion of the } L 4 / 5 \text { facet joint and the plane between } \\
\text { the muscle and subcutaneous tissue }\end{array}$} \\
\hline
\end{tabular}

Table 3: Measurement procedures of the ultrasound assessment.

(Abbreviations: $r$ : relatively)

The chest excursion was measured with an inelastic tape at the height of the nipples. The difference in the data measured at the end of the inspiration and at the end of the expiration was recorded as chest excursion in $\mathrm{cm} .{ }^{50}$

The inspiratory functions were assessed with the measuring protocols of the POWERbreathe KH2 device (POWERbreathe Ltd, Warwickshire, UK.). During testing the maximal inspiratory pressure (MIP) $(\mathrm{cmH} 2 \mathrm{O})$, the patient had to inhale maximally against a closed airway from residual volume. Basically, the values of the MIP test provide information on the strength of the inspiratory muscles. ${ }^{51,52}$ The peak inspiratory flow (PIF) reflects the ability of the inspiratory muscles to contract rapidly and to overcome the inherent resistance and elastance of the respiration. ${ }^{52}$ Functioning of the diaphragm muscle correlates with MIP and PIF values. ${ }^{52}$ VOLUME is the average amount of air inhaled per breath. ${ }^{53}$ The applied tests were performed in an upright standing position, and verbal encouragement was given to help the subjects perform 
maximally. For each patient, the inhalation of the highest value, out of three repeat inhalations, was selected for analysis. ${ }^{54,55}$

The stability limit of the trunk was measured with the modified Functional Reach Test (mFRT) and the modified Lateral Reach Test (mLRT). The participant was sitting on a table, the hips and knees were flexed in $90^{\circ}$, and the feet were placed in a hip-distance apart. The initial reach was measured with the arms flexed to $90^{\circ}$. In case of the mFRT, the participants were sitting next to a wall (on which a tape measure was fixed), and they were asked to reach as far forward as they could. In the mLRTs, the measurement protocol was similar, but the participants were sitting with their back against the wall, and they were asked to reach as far on the left and on the right sides as they could. It was not allowed for the participants to take a step forward or to either side, or to raise the buttocks from the table. The amount of the reaching was assessed in $\mathrm{cm}$ by the distance between the start and end points. In the mLRT, both the left and the right sides were assessed. ${ }^{35}$

\subsubsection{Data collection and analysis}

The data analysis and the calculations were executed with a Microsoft Office Excel, STATISTICA 13 and IBM SPSS Statistics 24 software. The Shapiro-Wilk test was used as normality test. The level of significance was set at $\mathrm{p}<0.05$.

\section{Ultrasound data analysis}

Test-retest reliability of the ultrasound imaging was checked by intra-class coefficients. To compare the change between the before and after data a two-way repeated measures ANOVA mixed model was performed where the three repetitions were also taken into account. Results are given as estimated marginal means with their standard errors. To avoid significant changes by occasion, individual P-values were corrected by the step-down Bonferroni.

\section{Data analysis for inspiratory functions and stability limit test}

A two-way repeated measurement ANOVA was performed by using the general linear model (GLM) method. There was one within-subject effect (the change before and after the training) and one between-subject effect (control and diaphragm training groups). The main effects and their interaction were tested. A significant 'group*training' interaction expresses that the change of the means before and after the training is different in the two groups. For the mean difference of the change, a 95\% confidence interval was also calculated. Pairwise comparisons were performed by estimated marginal means on the interaction level. 


\section{Results}

\subsection{Results supporting thesis I.}

\subsubsection{Severity of pain}

The severity of the pain decreased from 5.76 (SD 0.69) to $2.73(\mathrm{~cm})(\mathrm{SD} 1.73)$ after the training in case of group LBP $(\mathrm{p}=0.007)$.

\subsubsection{The thickness of lumbar multifidus muscle}

For group LBP comparing the before and after data we found that the thickness of lumbar multifidus muscle increased in prone position in the contracted states, and a significant difference occurred in the left lumbar multifidus muscle $(\mathrm{p}=0.017)$. On the other hand, in the kneeling position also in group LBP some decrease of the thicknesses was found in every condition and it was significant in the left-sided lumbar multifidus muscle in the relatively relaxed state $(\mathrm{P}=0.009)$.

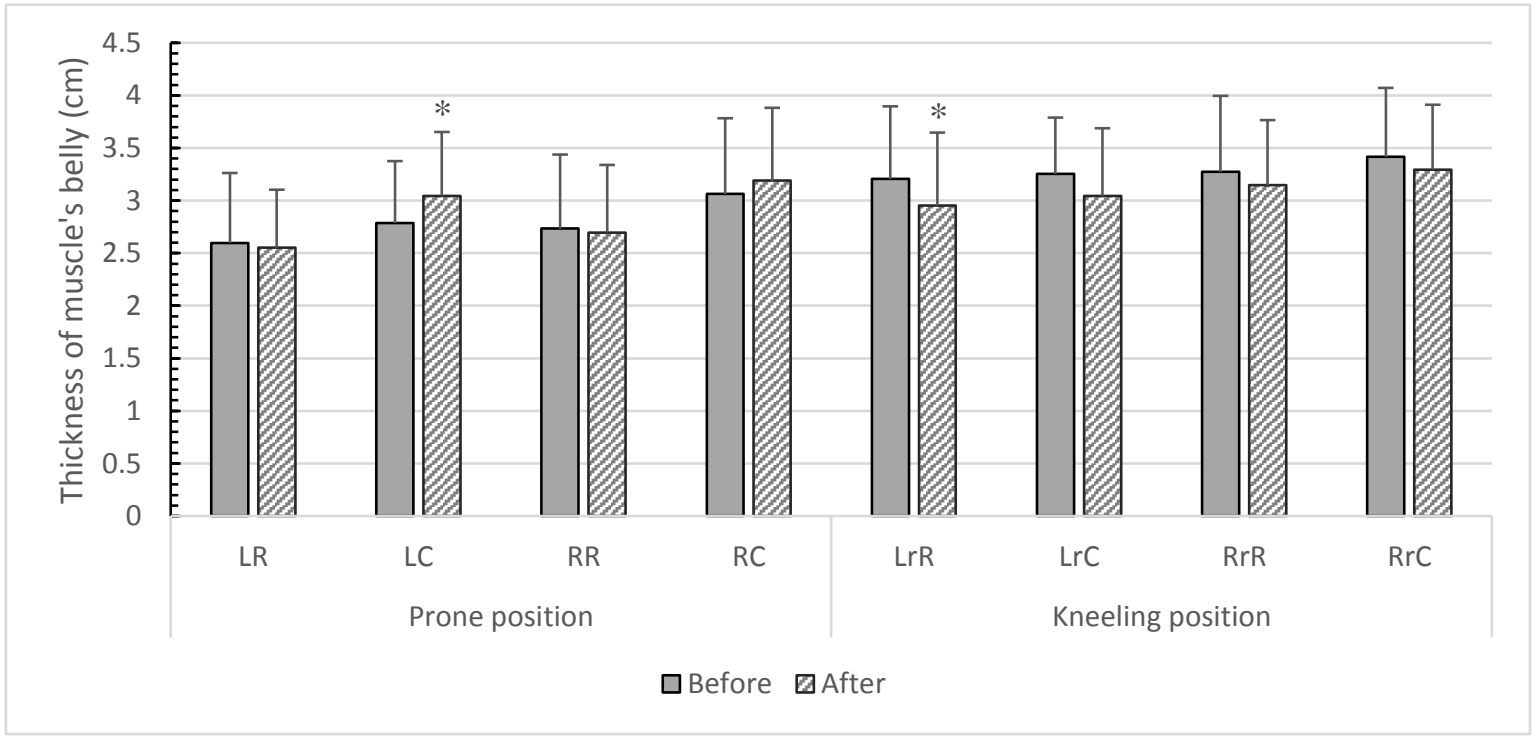

Figure 6: The thickness of lumbar multifidus muscle's belly in case of group LBP. $* p<0.05$

(Abbreviations: LR: left-sided, relaxed; LC: left-sided, contracted; RR: right-sided, relaxed; RC: right-sided, contracted; r: relatively)

In case of group $\mathrm{C}$, the thickness of lumbar multifidus muscle decreased in all conditions after the 8 weeks. Interestingly, reduction is more marked in the relaxed states of the muscle, than in the contracted states. Significant changes were found in the relatively relaxed states of the muscle in the kneeling position. The extent of the 
significant decreases in the left-sided $(\mathrm{p}=0.020)$, and in the right-sided lumbar multifidus $(\mathrm{p}=0.028)$ were approximately the same.

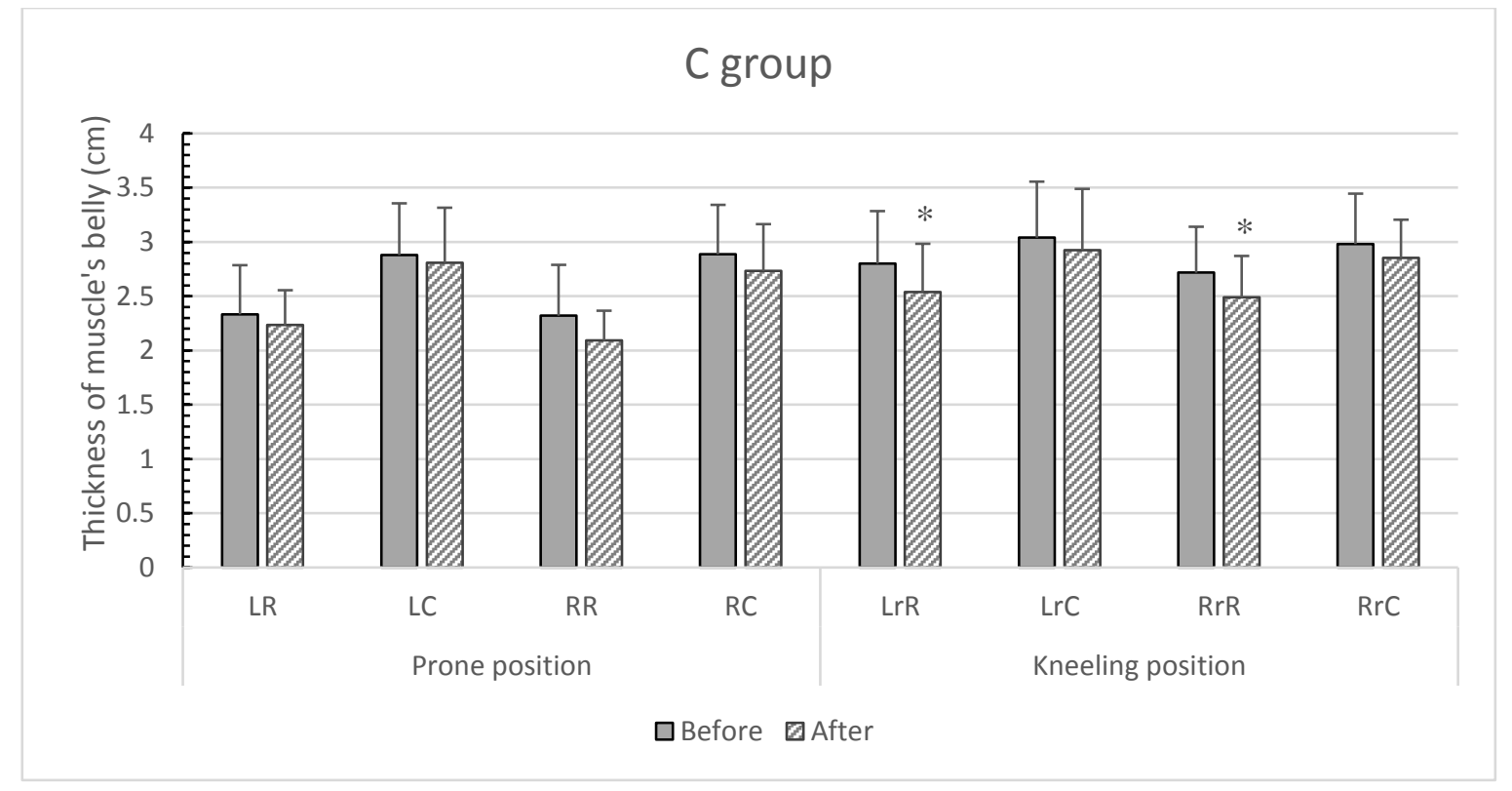

Figure 7: Thickness of lumbar multifidus muscle's belly in group C. *p $<0.05$ (Abbreviations: LR: left-sided, relaxed; LC: left-sided, contracted; RR: right-sided, relaxed; $R C$ : right-sided, contracted; $r$ : relatively)

\subsubsection{Modified standing heel-raise test}

Before the 8-week training program, members of group LBP performed 25.80 (SD 2.94) heel-raises on average and the members of group C implemented 30.70 (SD 4.32) heel-raises within 30s. There was significant difference between group C and LBP ( $\mathrm{p}=0.021)$, group $\mathrm{C}$ performed the test better than group LBP. After the 8 weeks, output of group LBP increased significantly $(\mathrm{p}=0.008)$. The members of the group implemented 33.20 (SD 4.64) heel-raises, yet the members of group $\mathrm{C}$ did not improve their performance significantly $(\mathrm{p}=0.918)$. Before the 8 -week period, a significant difference was found between the two groups $(\mathrm{p}=0.021)$ but this substantial difference vanished by the time of the post-tests $(\mathrm{p}=0.496)$. 


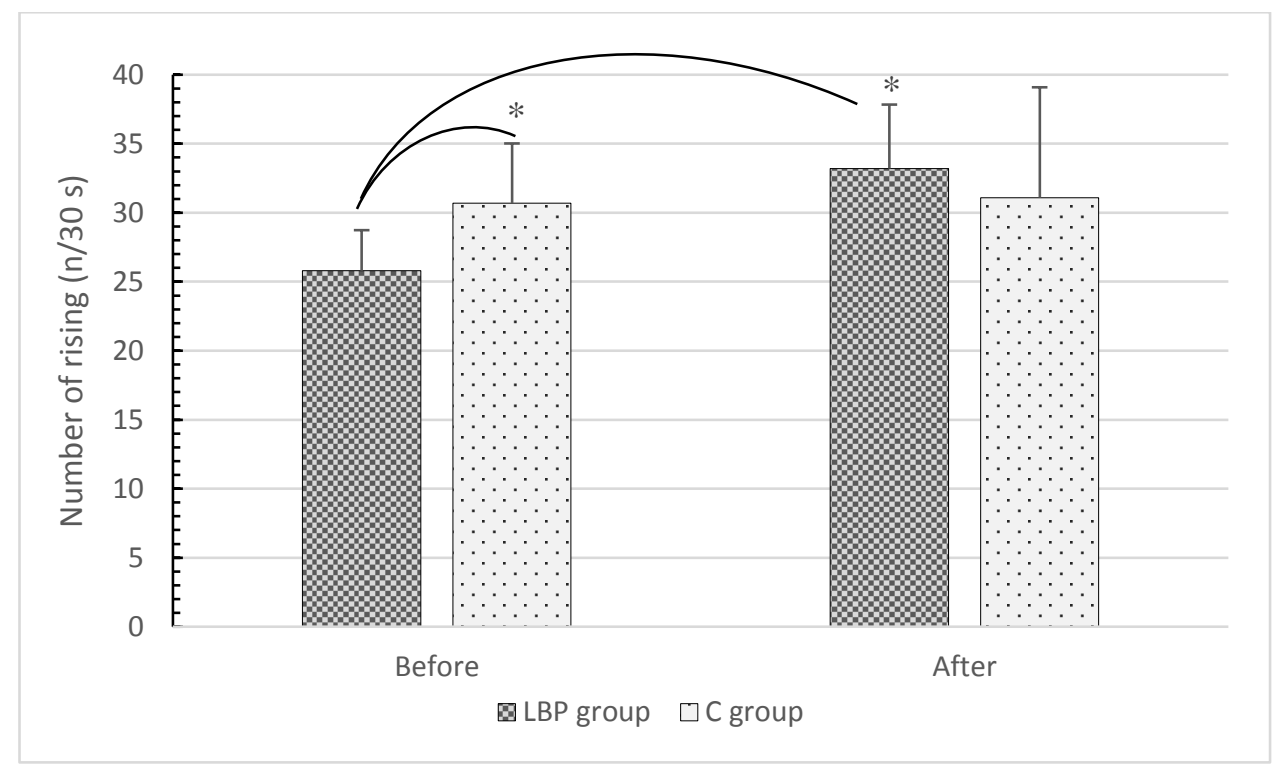

Figure 8: Number of heel-raises before and after the eight weeks. ${ }^{*} p<0.05$.

\subsection{Results supporting thesis II}

\subsubsection{Severity of pain}

Both groups showed significant improvement $(\mathrm{p}<0.01)$ concerning the pain after the training. In group $\mathrm{C}$, the average intensity of pain was $5.75( \pm 1.68)$ initially and after the training it changed to $2.14( \pm 1.9)(\mathrm{P}=0.000219)$, which means a $62 \%$ decrease. In group DT, the average intensity of pain was $5.70( \pm 1.74)$ before the treatment whereas after the 8-week-long training it was only $2.62( \pm 1.89)(\mathrm{P}=0.000017)$, so the decrease is $54 \%$.

\subsubsection{The thickness of the stabilizer muscles}

The results of the statistical comparison are summarized in Table 4. The estimated means and standard errors of the ultrasound assessment data are shown in Figure 9-14.

The results of the ultrasound assessment for the transversus abdominis muscle showed no significant differences in group $\mathrm{C}$ in supine position during relaxed and contracted state. In case of group DT significant increase in thickness was found in the relaxed state $(\mathrm{p}<0.05)$ but there were no significant changes in the contracted state in supine position. 


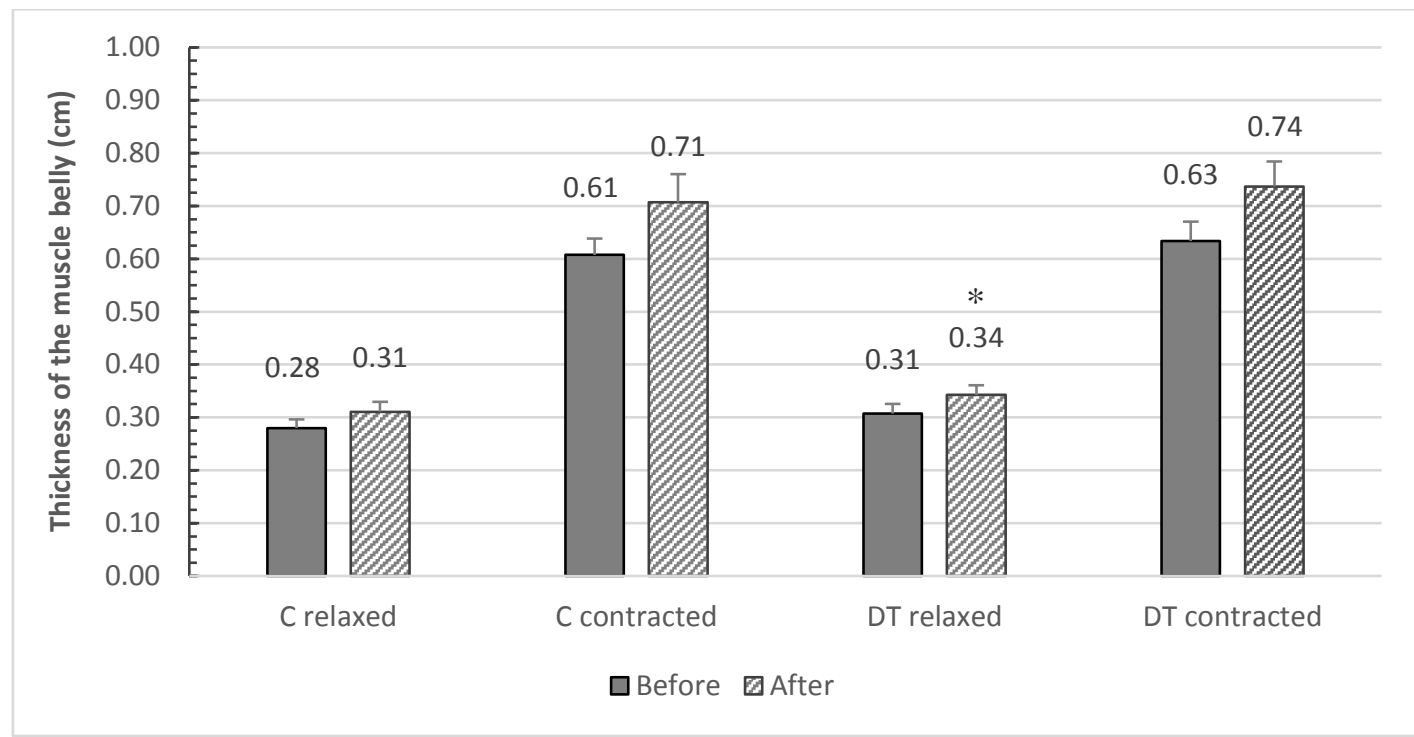

Figure 9: Changes in the thickness of transversus abdominis muscle in supine position, in the relaxed and in the contracted states (mean $\pm S E$ ). ${ }^{*} p<0.05$

(Abbreviations: C: control group, DT: diaphragm training group)

In sitting position there were no differences between the before and after data in group C. Contrary to this, in case of group DT the thickness of transversus abdominis muscle increased significantly in the relatively relaxed state $(p<0.01)$. However, there were no significant changes in the relatively contracted state.

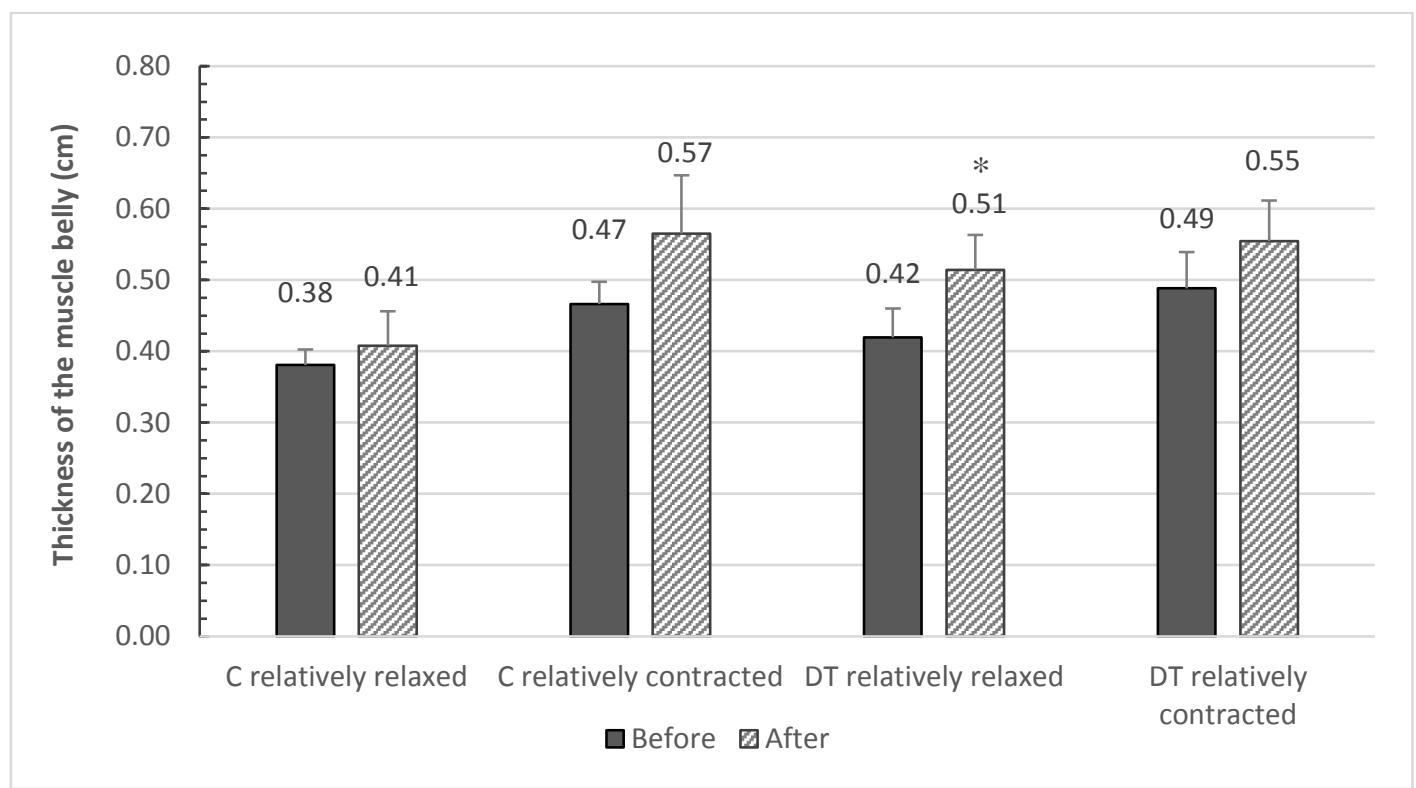

Figure 10: Changes in the thickness of transversus abdominis muscle in a functional, sitting position in the relatively relaxed and in the relatively contracted state (mean $\pm S E)$. $* p<0.05$

(Abbreviations: C: control group, DT: diaphragm training group)

As far as the diaphragm muscle's thickness is concerned, in supine position, there were no notable changes in case of group $\mathrm{C}$ in either state. On the other hand, for group 
DT significant increase was found in the thickness of the muscle belly both in the relaxed $(\mathrm{p}<0.05)$ and in the contracted states $(\mathrm{p}<0.01)$ after the training.

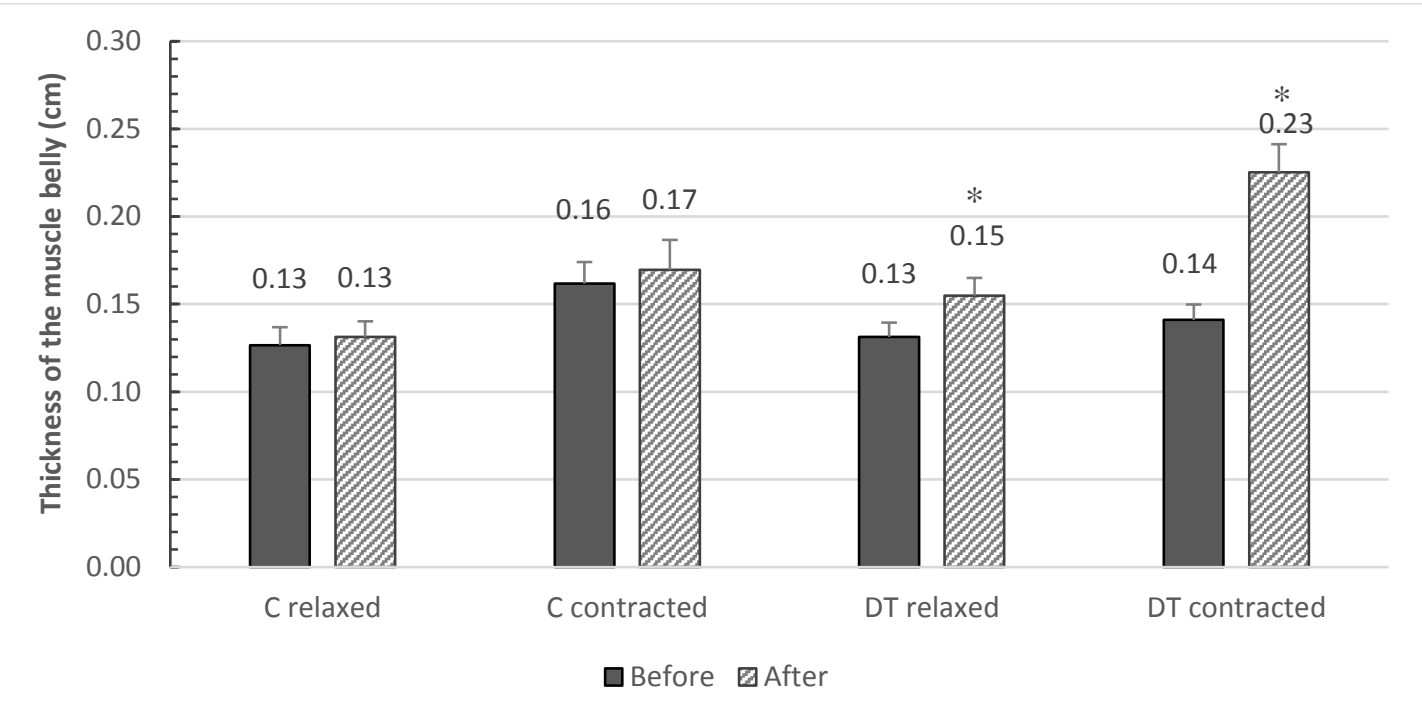

Figure 11: Changes in the thickness of diaphragm muscle in supine position in the relaxed and in the contracted state (mean $\pm S E$ ). ${ }^{*} p<0.05$; (Abbreviations: $C$ : control group, DT: diaphragm training group)

For the functional sitting position there were no notable changes in the relatively relaxed and the relatively contracted state in group $\mathrm{C}$, concerning the thickness of diaphragm. In contrast, group DT showed a significant increase in the relatively contracted state $(\mathrm{p}<0.01)$ but not in the relatively relaxed state.

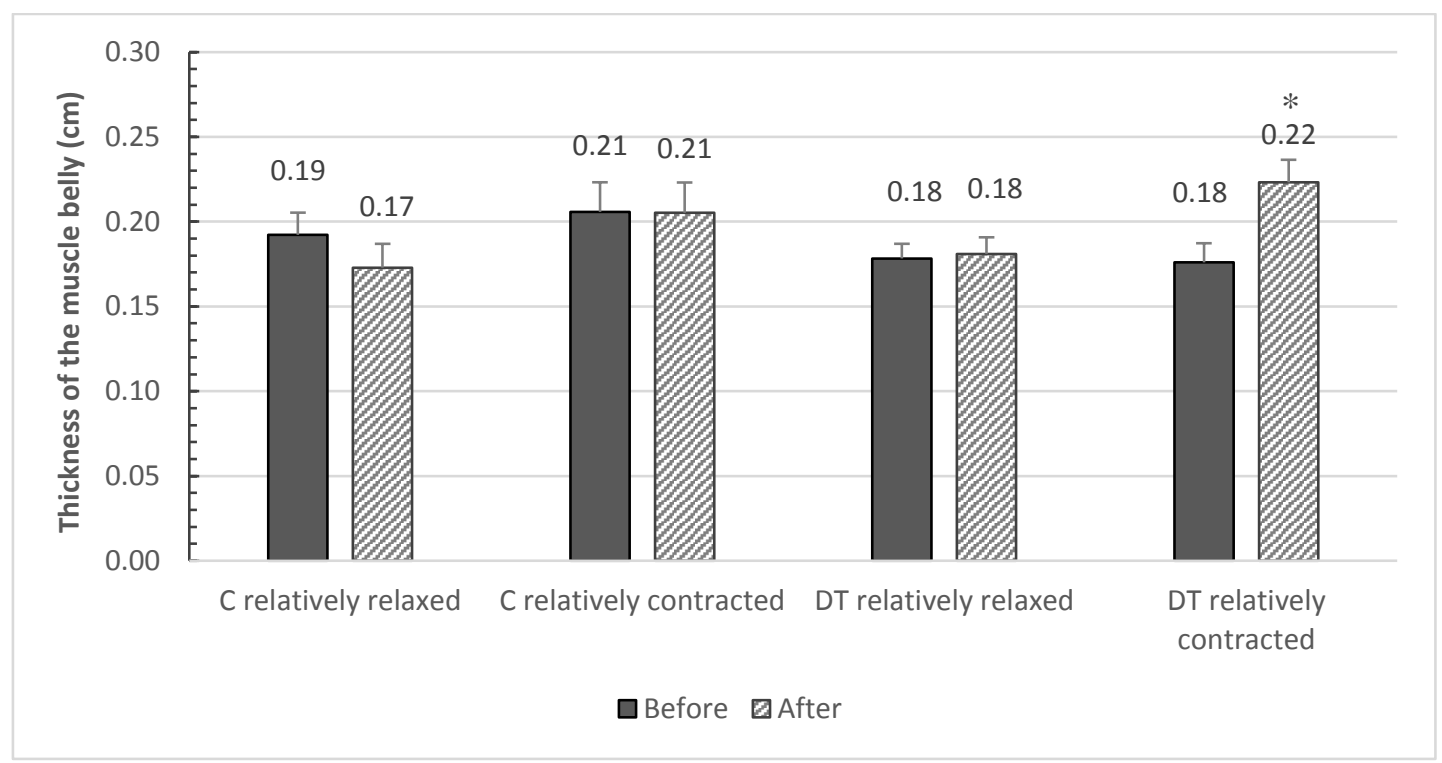

Figure 12: Changes in the thickness of diaphragm muscle in the functional, sitting position in the relatively relaxed and in the relatively contracted state (mean $\pm S E$ ). ${ }^{*} p<0.05$ (Abbreviations: C: control group, DT: diaphragm training group) 
In case of the relaxed and contracted states of the left- and right-sided lumbar multifidus there were no substantial changes found in group $\mathrm{C}$ in prone position. For group DT, significant increase was only found in the left-sided muscle in the relaxed state $(\mathrm{p}<0.01)$. There were no notable changes either in the relaxed and or the contracted states of the right-sided multifidus or in the contracted state of the left-sided lumbar multifidus muscle.

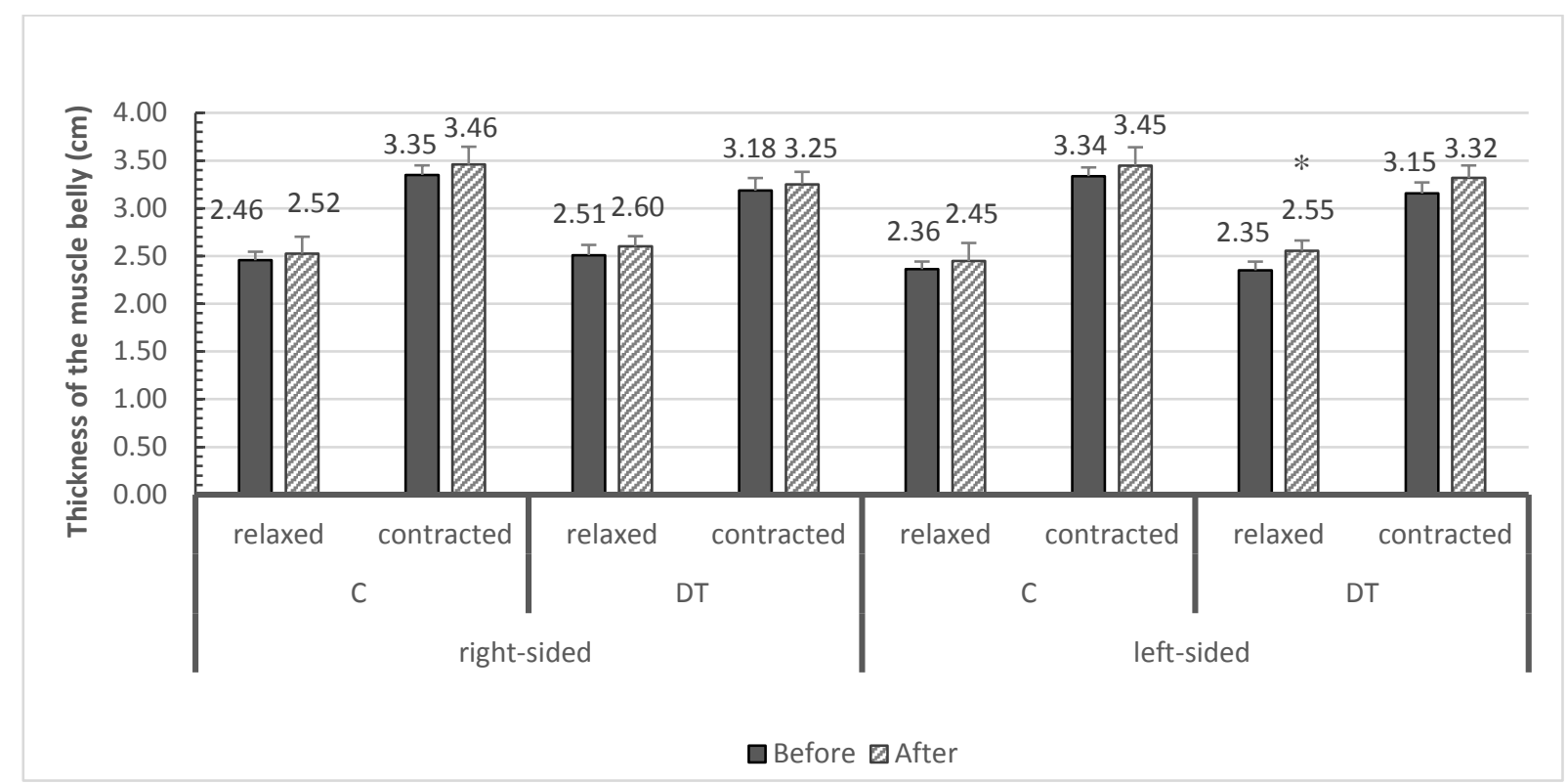

Figure 13: Lumbar multifidus muscle thickness in the prone position (mean $\pm S E$ ). $* p<0.05$

(Abbreviations: C: control group, DT: diaphragm training group)

In the sitting position there were no significant differences between the before and after data in group $\mathrm{C}$ in any states of lumbar multifidus muscle. For group DT significant increases were found in the relatively contracted states $(\mathrm{p}<0.05)$ in bilateral lumbar multifidus muscles as well as in the left-sided multifidus in the relatively relaxed state $(p<0.05)$. Concerning the right-sided multifidus muscle in the relatively relaxed state, there were no notable changes in the thickness of the muscle in the sitting position with regard to group DT. 


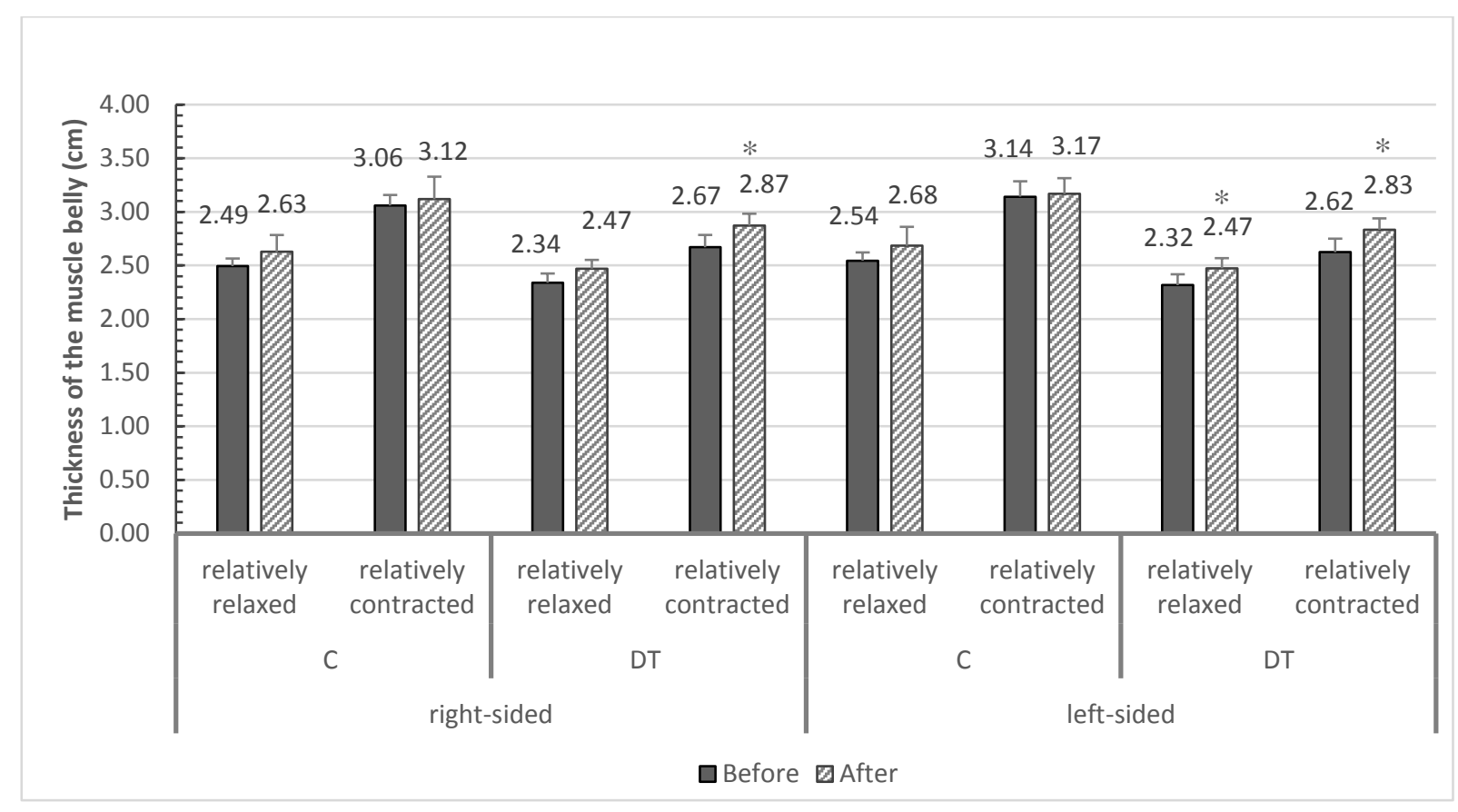

Figure 14: Lumbar multifidus muscle thickness during sitting (mean $\pm S E)$. ${ }^{*} p<0.05$ (Abbreviations: $C$ : control group, DT: diaphragm training group)

\subsection{Results supporting thesis III}

\subsubsection{Chest Excursion}

Group*training interaction was not significant showing that the trainings (conventional exercises completed with diaphragm strengthening training (group DT) vs conventional exercises alone (group C)) did not have a different effect. The mean difference of the change was 0.96 (95\% confidence interval: -0.33 to 2.25 ). The chest excursion increased by $42.09 \%$ in group DT as a result of the 8 -week intervention. In group C, the excursion of the chest increased by $20.16 \%$, after the training program (data are not shown). There was no difference between the groups before and after the intervention.

\subsubsection{Maximal Inspiratory Pressure (MIP)}

The two-way ANOVA resulted in a significant group*training interaction $(\mathrm{p}<0.0001)$ showing that the trainings resulted in different effects in group $\mathrm{C}$ and group DT. The mean difference of the change was 26.84 (95\% confidence interval: 15.48 to 38.20). The level of MIP was increased in both the intervention groups, by $53.44 \%$ in group DT, and by $8.99 \%$, in group C, after the intervention. No difference was found 
comparing the results of MIP on pretesting. After the 8-week training, significant difference was found between the groups $(\mathrm{p}=0.002)$.

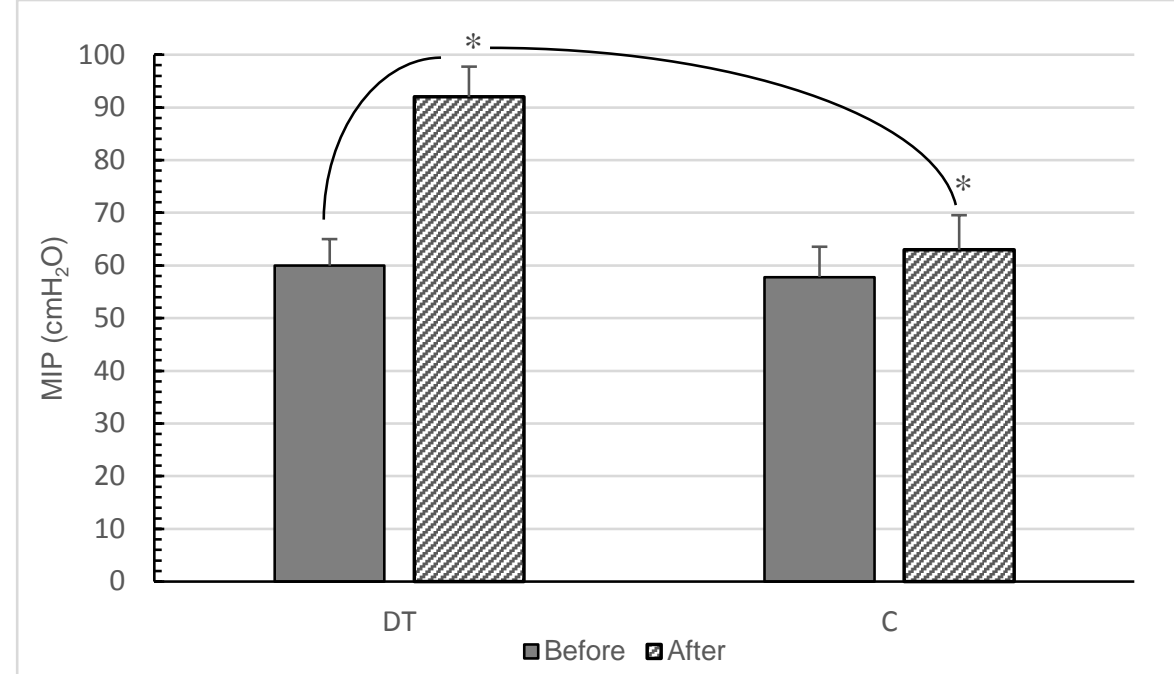

Figure 15: The values of MIP before and after the intervention (mean $\pm S E$ ). ${ }^{*} p<0.05$ Abbreviations: C: control group; DT: diaphragm training group; MIP: maximal inspiratory pressure; SE: standard error

\subsubsection{Peak Inspiratory Flow (PIF)}

Regarding the PIF results, group*training interaction was significant $(\mathrm{p}=0.025)$. The mean difference between the mean changes was 0.50 (95\% confidence interval: 0.07 to 0.94). In group DT, some improvement was recorded; the values of PIF was increased by $22.95 \%$. In group C, PIF was increased by $12.00 \%$. No difference was detected between groups DT and C before the intervention. After the 8-week intervention, there was no significant difference between the groups.

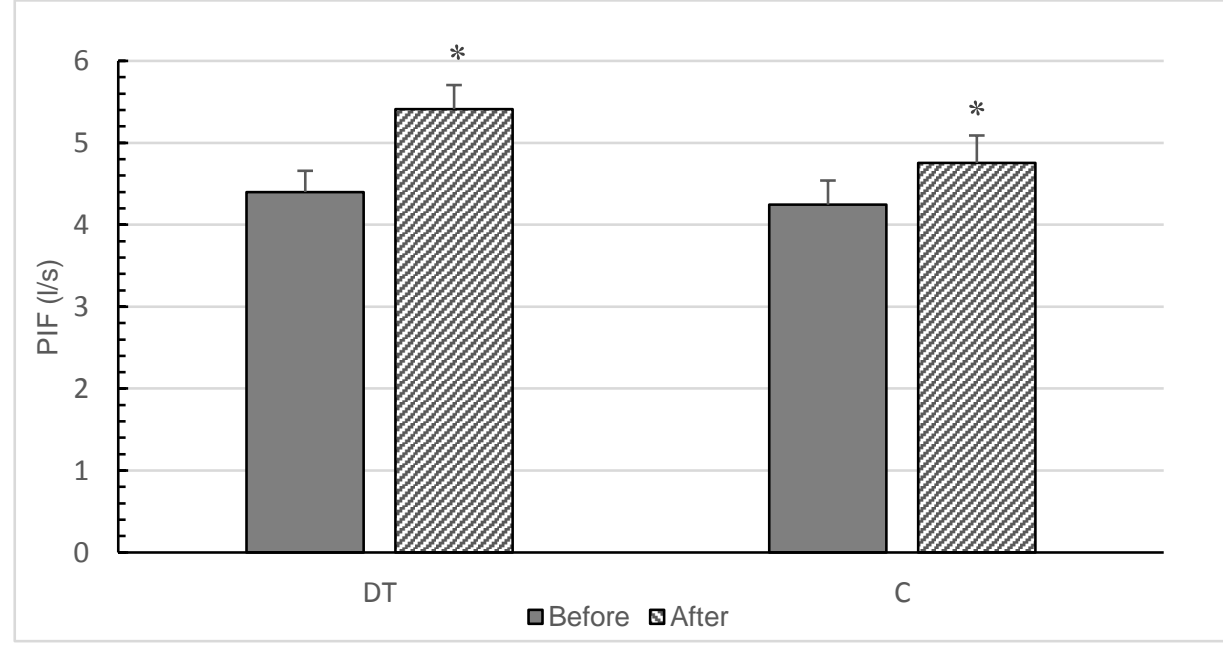

Figure 16: The values of PIF before and after the intervention (mean $\pm S E$ ). ${ }^{*} P<0.05$ Abbreviations: C: control group; DT: diaphragm training group; PIF: peak inspiratory flow; SE: standard error 


\subsubsection{VOLUME}

Group*training interaction was not significant; thus, the difference between the effect of trainings was not detectable. The mean difference between the mean change was 0.04 (95\% confidence interval: -0.28 to 0.35 ). Comparing the before and after data in group DT, we found that VOLUME was increased by $8.19 \%$. Concerning group C, VOLUME was increased by $7.25 \%$. In the results of the pretests, no difference was found between the groups in the values of VOLUME. After the 8-week diaphragm strengthening training, no significant difference was detected between groups $\mathrm{C}$ and DT in VOLUME data.

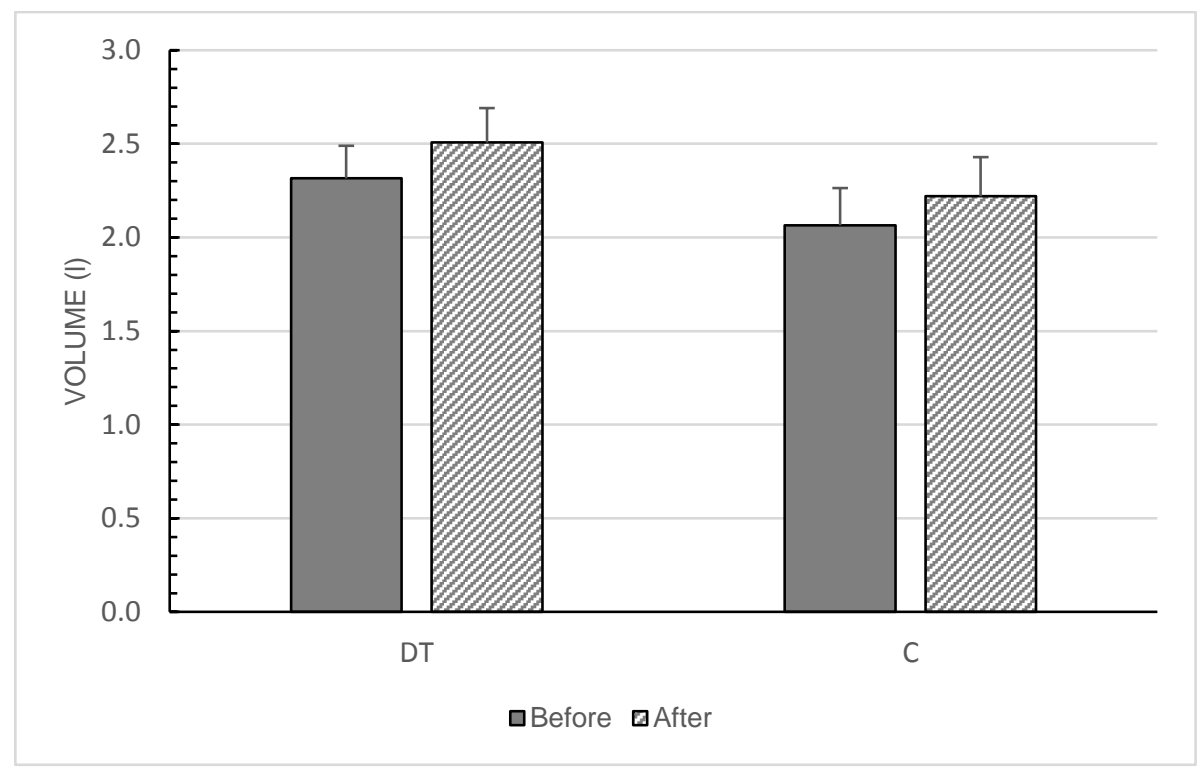

Figure 17: The VOLUME values (average amount of air inhaled per breath) before and after the intervention (mean $\pm S E$ ).

Abbreviations: C: control group; DT: diaphragm training group; SE: standard error

\subsubsection{Stability Limits of the Trunk}

In the modified Functional Reach Test (mFRT), group*training interaction was significant $(\mathrm{p}=0.017)$. The mean difference in the change was 5.12 (95\% confidence interval: 0.96 to 9.27). As an effect of the trainings, group DT improved by $15.84 \%$ and group $\mathrm{C}$, improved by $0.00 \%$. There was no significant difference between the groups before the intervention. After the training programs, there was a significant difference between groups $\mathrm{C}$ and DT ( $\mathrm{P}=0.01)$; significantly higher values were recorded in group DT in the mFRT.

Regarding the left-sided modified Lateral Reach Test (mLRT), the $\mathrm{p}$ value of the group*training interaction was 0.054 . The mean difference between the mean change was 
2.34 (95\% confidence interval: -0.004 to 4.72 ). As a result of the training program, a $14.57 \%$ increase was met in group DT. In group C, the average output was increased by $3.20 \%$. No significant differences were obtained in group comparison before the training and after the intervention.

In the right-sided mLRT, group*training interaction was significant $(\mathrm{p}=0.013)$. The mean difference of the change was 2.92 (95\% confidence interval: 0.66 to 5.18). After the training, group DT improved by $15.57 \%$, whereas group C improved by $1.97 \%$. No significant difference was present when the groups were compared before the intervention. After the training, the results showed a significant difference between the groups; group DT achieved a better improvement in the right-sided mLRT $(\mathrm{p}=0.03)$.

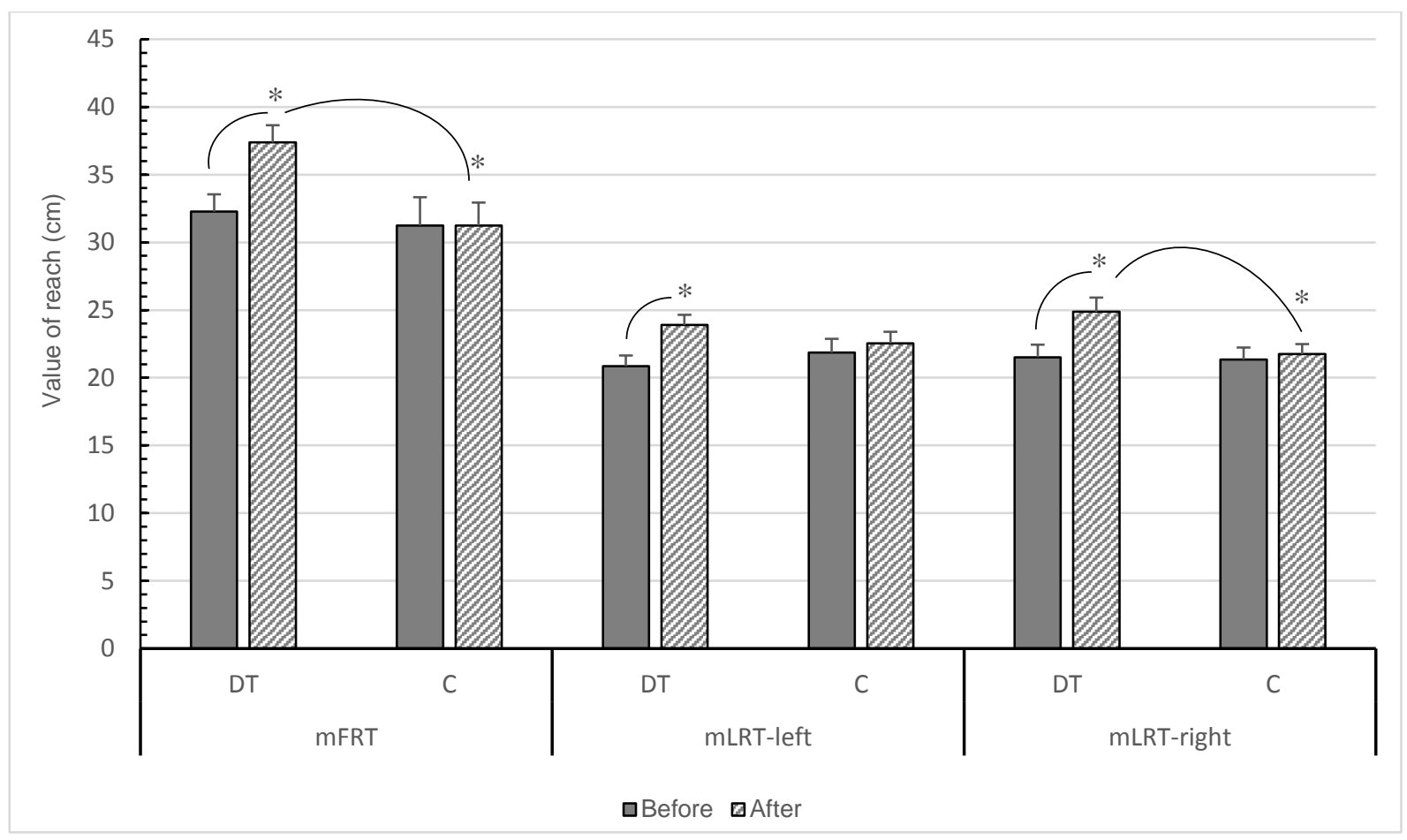

Figure 18: The results of the trunk stability tests before and after the intervention (mean $\pm S E) .{ }^{*} p<0.05$

Abbreviations: $C$ : control group; DT: diaphragm training group; mFRT: modified functional reach test; $m L R T$-left: left-sided modified lateral reach test; $m L R T$-right: right-sided modified lateral reach test; SE: standard error 


\section{Discussion}

Main findings of our study are that an 8-week training program based on conventional exercises is a viable way to improve the thickness of lumbar multifidus muscle, postural control and decrease the pain intensity. However, an extra diaphragm strengthening exercise program improves the whole active stabilizer system of the trunk, the inspiratory functions and stability limits of the trunk as well besides the effects of the conventional training (pain intensity decreases, postural control improves). Therefore, we can say that conventional exercises completed with diaphragm training offers more benefits and results in a better improvement in functional capacity in patients with LBP.

\subsection{Effects of the conventional exercises alone}

In prone position the thickness of lumbar multifidus muscle increased after the training, when it was in contraction. When the ultrasonography was performed in the prone position, both in relaxed and contracted states of lumbar multifidus muscle were in the neutral states of the muscle's belly, as in this position the muscle is not influenced by the enhanced postural function seen in vertical positions. ${ }^{56}$ The thicker belly of lumbar multifidus in the contracted state of the prone position indicates the improved contractile ability of the muscle. ${ }^{57}$ Regarding the fact that multifidus muscle is smaller in patients with chronic $\mathrm{LBP}^{58}$ and the muscle shows a reduced ability to voluntarily contraction than in healthy people ${ }^{45}$, our results indicate a positive change in the condition of lumbar multifidus muscle.

Pain can be reinforced by increased co-contraction which may results in increased stiffness in the lumbar area and altered biomechanical loading. ${ }^{59}$ Pain solely can cause an increased muscle thickness. ${ }^{60}$ The pain-spasm-pain cycle is a motor control pattern causing pain. It has the effect of perpetuating the painful disorder, but it also protects the system by maintaining stability on a higher level ${ }^{61}$. Our results show significant reduction on pain level in group LBP. In the LBP patients there is a decrease tendency of muscle thickness in relaxed state, prone position. However, when the voluntary contraction occurred in prone position the thickness of muscle belly increased. Besides this, in kneeling position the thickness of multifidus lumborum muscle decreased even though this posture challenge multifidus muscle more than the applied passive, prone position. ${ }^{56}$ The pain relief may have reduced the strain of lumbar multifidus muscle which resulted 
in the decrease of its thickness. We suppose that this kind of changes show that the increased co-contraction (observed in chronic LBP) turned in a more normal functioning, exerted by our training program. With the lumbar pain being relieved by the intervention, the pain-spasm-pain cycle might have been broken. ${ }^{62}$ Breaking the pain-spasm-pain cycle may be an explanation for the significant decrease in the thickness of lumbar multifidus muscle during kneeling in case of group LBP.

To date conflicting evidences can be found regarding the stabilizer muscles' role and the advantages of their strengthening in case of LBP. Only one muscle should not be highlighted during the management of LBP, considering that LBP is a largely complex condition. ${ }^{63}$ Therefore, our intervention contained strengthening exercises in a holistic way activating not only lumbar multifidus muscle but all members of the active stabilizer system of the trunk. If the function of even one muscle of the active stabilizer system deteriorates, it eventuates an increased demand on the other subsystems to maintain stability $^{6}$, thus the members of the stabilizer systems have an influence on each other. As it was mentioned previously, the thickness of multifidus muscle decreased in the kneeling position under all conditions after the intervention. Besides broken pain-spasm-pain cycle, further possible explanation for the decrease in multifidus' thickness is, that during kneeling all stabilizer muscles need to be more active to maintain the vertical position of the body than in the passive, prone position. ${ }^{56}$ Based on this observation we assume that the activation of lumbar multifidus was reduced by the neural system as a result of improved function of the whole stabilizer system exerted by the applied exercise therapy. Therefore, the increased tension of lumbar multifidus muscle was not needed any more.

In addition, the observed decrease in the muscle's thickness in the kneeling position in group LBP can be attributed to the change of the posture after our intervention. Former studies proved that individuals with low back pain prefer the ankle strategy to maintain stability ${ }^{28,64}$ and consequently they lean and position their centre of pressure forward. ${ }^{30}$ As a result of our intervention, a decreased thickness of lumbar multifidus muscle's belly was assessed in group LBP in the vertical, kneeling position. Thicker lumbar multifidus muscle, measured before the intervention, may be a sign of the forward leaning position ${ }^{65}$ which is preferred by people with low back pain. ${ }^{30}$ With the reduced pain intensity due to the training program and the improved stabilizer muscles' function, the postural alignment of the trunk might change into a more natural condition. ${ }^{28}$ The change of the posture from a forward leaning position to a normal posture influences the functioning of the stabilizer muscles of the trunk. ${ }^{65}$ The activity of the muscles in the low 
back area is lower in a normal posture than in a forward leaning position ${ }^{65}$, developed by LBP. After the 8-week training program decreases in the thickness of multifidus was observed by ultrasound examination in group LBP. Therefore, observed changes in lumbar multifidus muscle might be an indicator of the recovery of the normal posture.

We think that the increase in the thickness of lumbar multifidus muscle during contraction in the prone position and decrease during relaxation in prone and vertical, kneeling position was a result of a positive change in group LBP which occurred primarily due to the training program.

Surprisingly, a decrease occurred in the thickness of lumbar multifidus muscle under all conditions regarding group C. During the 8-week period, the members of group $\mathrm{C}$ continued their daily routine. Because of the decrease in the thickness of lumbar multifidus muscle which have been seen in group $\mathrm{C}$, the members of the group were asked if there had been any changes in their daily activities and if they had experienced any pain or stiffness linked to the low back area during the study. All members of group C claimed that during the autumn semester, when our study was conducted, they had spent much more time in sitting position than during the summer vacation before our research began. The students reduced the amount of their physical activity in order to be able to fulfil the requirements of their school. Interestingly, $50 \%$ of group $\mathrm{C}$ developed low back pain in the last few weeks of the research. Because of the reduced physical activity and the poor posture generally applied during sitting, the atrophy of lumbar multifidus is presumable. Former studies showed that an altered function and atrophy of lumbar multifidus muscle can be a cause of chronic LBP ${ }^{66,6}$. Our findings suggest that the decrease in the thickness of lumbar multifidus muscle may alerts us to the change in the functioning of multifidus. Therefore, it may be a kind of early sign of developing low back pain.

The results of the modified heel-raise test, which challenged more the postural function of the stabilizer muscles by using the unstable dynair, support our hypothesis that the vicious cycle was broken. People with chronic LBP have a reduced postural stability and they react worse to disturbing circumstances. ${ }^{67}$ The members of group LBP showed significant improvement after the intervention, although they had no chance to practice the modified standing heel-raise test and there were no exercises for strengthening the triceps surae muscle during the training period. Strengthening of the trunk and hip muscles was highlighted, thus presumably the stability of the proximal area (trunk) was improved facilitating better distal function (heel-raising) ${ }^{68}$ Because of the intervention, severity of the pain was reduced and the stabilizer muscles became stronger 
which resulted in significant increase on postural stability of the chronic LBP patients. In contrast with group LBP, there was no development in group C.

\subsubsection{Limitations}

One of the limitations of the study is the low number of participants but the recruitment of prospective participants for an extended study is already in progress. The mechanism of the changes in the thickness of lumbar multifidus muscle due to the training program has not been clarified in our study. The posture and the position of the center of pressure (COP) should be measured before and after the intervention, but the applied kneeling position is not suitable for detecting these changes with the device available that we have (NeuroCom Basic Balance Master). The standing position would be more appropriate to assess the forward leaning position seen in chronic LBP patients. It would be beneficial if we could compare lumbar multifidus muscle's thickness of the LBP patients to that of the healthy subjects, but the normalizing procedure is not clarified yet. ${ }^{69}$

\subsection{Effects of the conventional exercises completed with diaphragm training}

Based our results we can say that conventional training completed with diaphragm strengthening training increased the thickness not only of the diaphragm but also of the other stabilizer muscles such as transversus abdominis and multifidus muscle. The significant increase in diaphragm muscle thickness in supine position indicates the effectiveness of diaphragm training ${ }^{70}$ in a position where the other stabilizers are relaxed. Both of the applied training methods resulted in significant improvement in pain. Although it was more significant in case of group $\mathrm{C}$ whose members participated only in the conventional training. Concerning the thickness of the lumbar stabilizer muscles in group $\mathrm{C}$ there were no significant changes in any of the muscles resulting from the 8week-long intervention, which suggests diaphragm strengthening training can provide extra benefits. In addition to this, significant improvement was found in inspiratory functions and in the stability limits of the trunk, resulted by the applied diaphragm strengthening training. Therefore, it can be stated that diaphragm strengthening protocol improves successfully the functional capacity.

Concerning the intensity of pain both training methods resulted in significant improvement although it was more significant in group $\mathrm{C}$. The members of the groups 
took part in the same conventional training with the same exercises. However, the members of group DT faced a more difficult situation: they had to do the strengthening exercises parallel with the diaphragm strengthening training. Pain perception is highly subjective which is influenced by several psychological and emotional factors. ${ }^{71,72}$ Intensive strengthening exercises taken for a short period of time are not always very effective in reducing pain intensity. ${ }^{73}$ There are many factors (fear, structural abnormality, pain, posture reduction etc.) which maintain the vicious cycle in chronic low back pain, if intervention is capable of reducing one of the maintaining factors, the vicious cycle may be broken. ${ }^{62,74}$ Both of our trainings decreased pain significantly and the conventional training completed with diaphragm training increased the thickness of stabilizer muscles generating change in the condition of transversus abdominis, diaphragm and lumbar multifidus muscles. Based on our results, it can be stated that pain perception seems to has been influenced positively by the interventions, so it can be a possible way to influence the vicious cycle underlying chronic LBP.

The exercises of our conventional training program were the same in the two study groups. The training consisted of static and dynamic strengthening exercises for the trunk and hip muscles as well as proprioceptive training. All strengthening exercises were performed using external resistance (dumbbells, resistance bands, medicine ball) or body weight. A double-blind, randomized controlled trial proved earlier that both motor control and general exercises increase the thickness of lumbar multifidus and transversus abdominis muscle significantly in the case of low back pain patients as a result of an 8week-long training program. ${ }^{75} \mathrm{~A}$ previous study also showed that the thickness of diaphragm muscle increases as a consequence of a 4 -week-long diaphragm training. ${ }^{70}$ Based on the abovementioned findings and considering our results we can conclude that our conventional training completed with a diaphragm strengthening training is a possible way to increase the thickness of transversus abdominis, diaphragm and lumbar multifidus muscles.

In case of group DT, the thickness of transversus abdominis muscle increased significantly in the relaxed state (calm lying) but not in the contracted state when the subjects were asked to contract their abdominal muscles in supine position. We found similar muscle changes in the sitting position where the thickness of transversus abdominis muscle increased significantly in the relatively relaxed state when the sitting position was held but there were no notable changes during the weightlifting task in the relatively contracted state. The increase of the thicknesses in relaxed and relatively 
relaxed states may have occurred due to the effect of our intervention. ${ }^{75}$ The unchanged thickness parameter of the contracted state in the supine position maybe due to the limitation of our measurement procedure: the participants were asked to contract their abdominal muscles voluntarily without lifting their head or shoulders from the bed. This kind of contraction seems to be more dependent on the compliance of the participants. ${ }^{76,77}$ Moreover, this movement was not practiced during our program therefore the quality of the performance may have been diverse $\mathrm{e}^{77}$ and may not have been sufficient enough to show the effectiveness of the training. In addition to this, transversus abdominis muscle is a local stabilizer whose main function is more that of stabilization and not the implementation of movements ${ }^{9,10}$ and in supine position the demand for stabilization is minimal. ${ }^{78,79}$ There was no significant change in the thickness of transversus abdominis in the relatively contracted state either when the weightlifting was performed. It is well known that lifting tasks activate mainly the extensor group. ${ }^{80,81}$ Our results provide further evidence that lumbar multifidus has a more enhanced role in performing a weightlifting task, than transversus abdominis muscle. Therefore, the applied weightlifting task is may not be the most appropriate postural task to show the enhanced stabilizer function of transversus abdominis muscle.

The increased thickness of diaphragm muscle in relaxed and in contracted states in the supine position may show the effectiveness of the diaphragm strengthening training. ${ }^{70}$ The results show that the only condition where we could not find any increase in the thickness of diaphragm after the training was the relatively relaxed state in sitting position. This finding may be explained by the neutral vertical position of the trunk which was held only against gravity in this case. This posture does not require more enhanced stabilization from diaphragm muscle. ${ }^{82,11}$ Significant increase occurred in the thickness of diaphragm muscle when the weightlifting was performed, in the relatively contracted state. Movements of the upper limb challenge the diaphragm muscle as a stabilizer muscle more contrary to the simple tasks to maintain vertical position. ${ }^{11}$ In a previous study Hodges and co-workers assessed the functioning of diaphragm during a rapid movement of the arm. Their findings proved that increased activity of diaphragm occurs during this motion. ${ }^{11}$ The diaphragm of low back pain patients has an altered postural function compared to healthy subjects when isometric flexion against resistance of the upper- or lower limb was applied. ${ }^{21}$ In our training program several resistance exercises were performed by the upper limb when the vertical posture of the trunk needed to be held and the participants used the POWERbreathe device parallel with upper limb exercises. Our 
results show that there is an increased thickness of diaphragm during the lifting task after training which may suggest that the role of diaphragm muscle has improved in maintaining trunk stability during upper limb activities as a result of the applied 8-weeklong training. Our findings are in line with a previous study of Dülger et al. ${ }^{83}$ They found that as a result of a stabilization exercise program the thickness of diaphragm increased as well as the stability of the lumbar spine. ${ }^{83}$

Considering lumbar multifidus muscle in prone position, significant increase was only found in case of the left-sided one in the relaxed state. There were no significant changes in case of contracted states of the left-sided muscle or in both states of the rightsided multifidus. Like in case of transversus abdominis, the main function of lumbar multifidus is not implementation of movements but the segmental stabilization of the lumbar spine as it produces compression with minimal movement torque. ${ }^{81}$ This may be the reason for the unchanged thickness in the contracted state, when the patients were asked to lift their head and shoulders from the bed. The role of lumbar multifidus muscle in stabilization is highlighted in rotational movements and therefore in movements of the contralateral limb. ${ }^{84}$ Every participant was right-handed in our study which might have influenced the training effects: our results revealed that in prone position the left-sided (contralateral to the dominant arm) muscle's thickness improved significantly in the relaxed state. The resistance exercises were probably more effectively performed with the dominant (right-sided) arm. ${ }^{85}$ In sitting position the thickness of both the left- and right sided multifidus muscle increased in the relatively contracted state (during weightlifting) and the left-sided lumbar multifidus muscle's thickness also increased in the relatively relaxed state as well (during holding the vertical position of the trunk). Contrary to the prone position when sitting, the postural demand is enhanced and lumbar multifidus muscle can act directly on the lumbar vertebral column producing the anti-flexion (extension) moment. ${ }^{84}$ During weightlifting (relatively contracted state) this anti-flexion moment of bilateral multifidus muscle is more important. ${ }^{81}$ The increased thickness possibly occurred as a result of our training method. The only unchanged thickness in sitting position was found in the right-sided (ipsilateral to the dominant arm) lumbar multifidus muscle in relatively relaxed state. The unchanged thickness may be explained by the influence of right-handedness on the training and/or on the testing procedure. In case of our testing procedure one dumbbell was lifted with both hands therefore it is possible that the dominant arm had a bigger contribution in the exercise. ${ }^{85}$ Further investigations are needed using two dumbbells to support this hypothesis. 
The differences between group DT and C in the change of the thickness of the stabilizer muscles indicate that diaphragm training has an extra advantage compared to a conventional training program. Further investigations are warranted to explore the mechanism behind the changes, but some possible assumptions can be made:

The effect of deep abdominal muscle exercises on respiratory function was assessed in a previous study. ${ }^{86}$ Deep abdominal muscles and diaphragm play an important role in maintaining and increasing the intra-abdominal pressure by their cocontraction. ${ }^{87,88}$ The finding of this research shows that enhanced diaphragmatic function achieved via deep abdominal muscle strengthening exercises did not only increase respiratory volume but also enhanced the stability of the lumbar spine through the cocontraction of transversus abdominis. ${ }^{86}$ Contrary to their above-mentioned training method, we have placed emphasis on the diaphragm muscle strengthening in our training program but as a consequence, transversus abdominis muscle may be strengthened in this alternative, indirect way.

People with chronic LBP have a higher diaphragm position, a smaller diaphragm excursion and greater diaphragm fatigability ${ }^{22,21}$ which is compensated by increased lung volume to provide adequate increase in intra-abdominal pressure. ${ }^{22}$ Diaphragm strengthening training is a viable method to enhance the excursion of the diaphragm and increasing the mobility of the muscle. ${ }^{89,90} \mathrm{We}$ assumed that a higher excursion of the diaphragm occurred due to the our diaphragm strengthening training which further influenced the function of the diaphragm muscle during breathing and postural stabilization. ${ }^{28}$ Significant increases were found in the diaphragm thickness when the weightlifting task was performed in sitting position. The increased thickness during weightlifting suggests that the role of diaphragm muscle in maintaining trunk stability may have been improved.

Previous studies suggested that increase in the respiratory output causes an increased excursion of the body in space. ${ }^{91,92}$ Another previous study reported that normal inhalation is linked to the extension of the lumbar spine in standing posture. ${ }^{18}$ Significant changes in posture and significant enhance occurs in the activation of erector spinae muscle when the inspiration effort increases. ${ }^{93}$ The fact that our training combined exercises in vertical positions with forced inhalation exercises can explain the training effects especially the increase in the thickness of lumbar multifidus muscle in sitting posture. 
Considering the inspiratory functions and stability limits of the trunk, there was a significant difference between the groups after the 8-week intervention period in mFRT and right sided mLRT; group DT reached a greater improvement than group C. In the left sided mLRT, the value of the group*training interaction was 0.054 , which is very close to the nominal significance level. It may suggest that there is a difference in the effects of the training between the groups. Regarding the limits of stability (LOS) (mFRT, mLRT) results, the conventional exercises completed with the diaphragm strengthening protocol (group DT) seem to lead to better results than the conventional exercises alone (group C). Concerning the inspiratory tests, a significant group*training interaction was found in the measurements of MIP and PIF, showing that there was a difference between the training types in improving the inspiratory function. In case of MIP a significant between-group difference was found after the interventions. Group DT reached higher values in the inspiratory tests, which may indicate the extra advantages of the diaphragm training. However, in values of chest excursion and VOLUME, the group*training interaction was not significant; therefore, the difference between the effects of the applied training methods (conventional exercises vs conventional exercises completed with the diaphragm strengthening protocol) could not be detected. An increase in the output of group C can be seen, but the improvement in group DT was more meaningful, although significant between-group differences were not found after the trainings. The applied conventional exercise program consists of different types of exercises, which probably affect the respiratory muscles. ${ }^{94}$

The diaphragm is an essential breathing muscle; however, it also has a remarkable role in preserving the segmental stability of the lumbar spine by maintaining and increasing the intra-abdominal pressure during postural tasks. ${ }^{19}$ Individuals with low back pain have a disturbed proprioceptive input from the low back area; therefore, they achieve worse results in the stability limit tests (like functional and lateral reach tests) than healthy individuals. ${ }^{95}$ The function of the diaphragm muscle deteriorates if nonspecific low back pain occurs. ${ }^{22}$ In these cases, the diaphragm has a higher position, decreased mobility, and greater fatigability. ${ }^{22}$ Our results suggest that as an effect of the diaphragm strengthening training, both functions of diaphragm muscle have improved, both the breathing and the postural functions. With exercising the diaphragm, all these aforementioned dysfunctions may be decreased; a stronger, more mobile muscle ${ }^{96}$ may be more effective in increasing the intra-abdominal pressure, and therefore maintaining the lumbar stability. 
Considering the evidence that pain deteriorates proprioception ${ }^{25}$, our results may indicate that the positive change in the severity of pain together with the increased LOS values might be a sign of an improved proprioception from the lumbar area represented by better mobility. The deteriorated proprioceptive input might cause postural changes in vertical positions in people with low back pain; individuals tend to lean more forward if low back pain develops ${ }^{30}$ and they prefer ankle strategy to the normal multisegmental strategy in postural control. ${ }^{28,64}$ The increased stability limits of the trunk might be the indicator of a more complex postural strategy applied by group DT. These results are in line with the findings of a former study describing that improved postural function with the significantly decreased severity of pain may contribute to the normal, multisegmental strategy in patients with nonspecific chronic low back pain. ${ }^{28}$

The mobility of the lumbar spine and having strong, well-functioning extensor muscles are essential to perform the mFRT and mLRT. ${ }^{95}$ The synergistic function of the global stabilizers (superficial extensors) and local stabilizer muscles (lumbar multifidus, transversus abdominis, pelvic floor muscles, and the diaphragm) has a major role during performing a postural task ${ }^{97}$, for example, during the stability limit tests in our study. It has already been demonstrated that deterioration in the function of even one muscle of the active stabilizer system eventuates an increased demand on the other subsystems to maintain stability ${ }^{6}$; thus, the members of the stabilizer systems have an influence on each other. Our results concerning the inspiratory tests show that the inspiratory function of the diaphragm improved after the 8-week diaphragm strengthening training. It is also described, that the diaphragm strengthening training might have a significant effect on the other stabilizer muscles than the diaphragm, that is, the increased thickness of muscle belly of the transversus abdominis and lumbar multifidus muscles. The significant improvement in functional capacity of the local stabilizer muscles (increased thickness and improved inspiratory function) may result in the increased stability limits of the trunk. This finding implies that in case of nonspecific chronic low back pain, an 8-week diaphragm training complemented with conventional exercises may be superior to the conventional exercises alone in improving the functional capacity of the trunk.

\subsubsection{Limitations}

A limitation of this study is that by using ultrasonography we could not discriminate between the increase of muscles' thickness as result of the changes of the tone and activation pattern as and muscle hypertrophy which occurred as a result of the 
strengthening training. Another limitation of this study is the presumption that the compliance of the subjects was on the same level but it could not be controlled by objective methods. To assess transversus abdominis muscle in contraction in supine position the patients were asked to contract their abdominal muscles voluntarily. This exercise needs a more developed understanding of the movement therefore we could not be sure that everyone performed the contraction on the same level. ${ }^{77,76}$ This procedure would have been better if we had allowed the flexion of the trunk to a specified extent. In case of sitting positions, the subjects were asked to hold the neutral position of the trunk which was controlled by a physiotherapist but not with objective methods. Therefore, some inclination of the trunk may have happened during the ultrasound measurement procedure. For further studies the vertical position should be controlled in a more objective manner. An additional limitation of this study is that the applied inspiratory maneuver during the MIP test is a highly effort-dependent test. ${ }^{54}$ However, it is proved that a co-operative subject can activate the diaphragm maximally during voluntary inspiratory efforts. ${ }^{98}$ The activity of the diaphragm was not measured directly in our study, therefore the accurate amount of the contraction of diaphragm is not known when performing the MIP test, although verbal encouragement was given to help the subjects performing maximally. 


\section{Conclusion and new results}

A part of the significant results of this study are that changes occurred in the thickness of lumbar multifidus muscle, the postural stability improved, and the low back pain was relieved as a result of the applied conventional training program. Despite the low sample size, significant changes and clear tendencies were found. The decreased thickness of multifidus muscle's belly and the simultaneously appearing low back pain in case of healthy individuals draws attention to the importance of lifestyle in the occurrence of low back pain. Moreover, the decrease in muscle's thickness poses the possibility that this change may be a kind of early sign of developing low back pain. However, the role of multifidus muscle in chronic LBP is contradictory yet. ${ }^{99}$ In conclusion, we can say that the applied conventional exercise therapy is a viable way to improve the functions in patients with chronic LBP. Additionally, the observed changes in muscle function may help to understand better the altered muscular activation pattern in low back pain.

To evaluate thesis II and III, the training effects of a conventional training program and a conventional training completed with diaphragm strengthening were examined. The diaphragm strengthening training has never been tested before as a solution for LBP. Our recent results clearly show that conventional exercises completed with diaphragm training adds more benefits for LBP people than conventional exercises alone.

Based on our results we suggest that the applied diaphragm strengthening training is an effective and viable way to increase the thickness of the stabilizer muscles of the lumbar spine such as transversus abdominis, diaphragm and lumbar multifidus muscle. We can say that this training method is effective in reducing the severity of lumbar pain. However conventional training alone was more efficient taking into consideration the results of VAS. The significantly increased thickness of lumbar stabilizer muscles may lead to a better postural stability of the trunk and eventuate a better function in people with LBP. Our findings clearly show that our intervention can have an influence on the diaphragm's postural function during upper limb lifting tasks. Moreover, with the applied diaphragm strengthening exercises the inspiratory functions also improved, which can be considered as additional benefits of the training. The importance of applying nonpharmacological treatments, such as physical exercises, is well-known in the reduction of the intensity of low back pain. ${ }^{41}$ The results suggest that our conventional training enhanced with diaphragm strengthening may be a viable therapeutic approach in the complex treatment of chronic nonspecific low back pain. Nevertheless, there are several 
low back pain patients who are not capable to perform the conventional exercises because of the intensity of the pain or as a result of other medical conditions. Since stability limit and appropriate postural control are the bases of functional capacity ${ }^{100}$ we suggest that the diaphragm training would be an appropriate option for these patients to improve their functional level. We suggest a further consideration focusing on whether diaphragm training alone would be a new therapeutic approach for those who are not capable of performing conventional exercises. Moreover, the diaphragm strengthening training would be a favorable additional method for everyone who suffers from the consequences of lumbar pain, and it may also be beneficial in the prevention of nonspecific chronic low back pain. 


\section{References}

1. Hoy D, March L, Brooks P, et al. The global burden of low back pain: estimates from the Global Burden of Disease 2010 study. Ann Rheum Dis. 2014;73(6):968974.

2. Duthey B. Low back pain. In: Priority Medicines for Europe and the World "A Public Health Approach to Innovation" Update on 2004 Background Paper. Vol BP. ; 2013:4-23.

3. Deyo RA, Weinstein JN. Low Back Pain. N Engl J Med. 2001;344(5):363-370. d

4. Dewitte V, De Pauw R, De Meulemeester K, et al. Clinical classification criteria for nonspecific low back pain: A Delphi-survey of clinical experts. Musculoskelet Sci Pract. 2018;34:66-76.

5. Salathé CR, Melloh M, Crawford R, Scherrer S, Boos N, Elfering A. Treatment Efficacy, Clinical Utility, and Cost-Effectiveness of Multidisciplinary Biopsychosocial Rehabilitation Treatments for Persistent Low Back Pain: A Systematic Review. Glob spine J. 2018;8(8):872-886.

6. Fritz JM, Erhard RE, Hagen BF. Segmental Instability of the Lumbar Spine. Phys Ther. 1998;78(8):889-896.

7. Panjabi MM. Clinical spinal instability and low back pain. J Electromyogr Kinesiol. 2003;13(4):371-379.

8. Hodges PW, Moseley GL. Pain and motor control of the lumbopelvic region: effect and possible mechanisms. J Electromyogr Kinesiol. 2003;13(4):361-370.

9. Bruno P. The use of \&quot;stabilization exercises\&quot; to affect neuromuscular control in the lumbopelvic region: a narrative review. J Can Chiropr Assoc. 2014;58(2):119-130.

10. Macintosh JE, Bogduk N, Gracovetsky S. The biomechanics of the thoracolumbar fascia. Clin Biomech. 1987;2(2):78-83.

11. Hodges PW, Butler JE, McKenzie DK, Gandevia SC. Contraction of the human diaphragm during rapid postural adjustments. J Physiol. 1997;(2):539-548.

12. Hodges PW, Gandevia SC. Activation of the human diaphragm during a repetitive postural task. J Physiol. 2000;(1):165-175.

13. Kolar P, Sulc J, Kyncl M, et al. Stabilizing function of the diaphragm: dynamic MRI and synchronized spirometric assessment. J Appl Physiol. 2010;109(4) 106471. 
14. Ning X, Zhou J, Dai B, Jaridi M. The assessment of material handling strategies in dealing with sudden loading: The effects of load handling position on trunk biomechanics. Appl Ergon. 2014;45(6):1399-1405.

15. Zhou J, Dai B, Ning X. The assessment of material handling strategies in dealing with sudden loading: influences of foot placement on trunk biomechanics. Ergonomics. 2013;56(10):1569-1576.

16. Sweeney N, O’Sullivan C, Kelly G. Multifidus muscle size and percentage thickness changes among patients with unilateral chronic low back pain (CLBP) and healthy controls in prone and standing. Man Ther. 2014;19(5):433-439.

17. YATES JW, KARWOWSKI W. An electromyographic analysis of seated and standing lifting tasks. Ergonomics. 1992;35(7-8):889-898.

18. Lewit K. Relation of faulty respiration to posture, with clinical implications. J Am Osteopath Assoc. 1980;79(8):525-529.

19. Hagins M, Lamberg EM. Individuals with Low Back Pain Breathe Differently Than Healthy Individuals During a Lifting Task. J Orthop Sport Phys Ther. 2011;41(3):141-148.

20. Beeckmans N, Vermeersch A, Lysens R, et al. The presence of respiratory disorders in individuals with low back pain: A systematic review. Man Ther. 2016;26:77-86.

21. Kolář P, Šulc J, Kynčl M, et al. Postural Function of the Diaphragm in Persons With and Without Chronic Low Back Pain. J Orthop Sport Phys Ther. 2012;42(4):352-362.

22. Janssens L, Brumagne S, McConnell AK, Hermans G, Troosters T, GayanRamirez G. Greater diaphragm fatigability in individuals with recurrent low back pain. Respir Physiol Neurobiol. 2013;188(2):119-123.

23. Mohan V, Paungmali A, Sitilerpisan P, Hashim UF, Mazlan MB, Nasuha TN. Respiratory characteristics of individuals with non-specific low back pain: A crosssectional study. Nurs Health Sci. 2018;20(2):224-230.

24. Goubert D, De Pauw R, Meeus M, et al. Lumbar muscle structure and function in chronic versus recurrent low back pain: a cross-sectional study. Spine J. 2017;17(9):1285-1296.

25. Brumagne S, Cordo $\mathrm{P}$, Verschueren S. Proprioceptive weighting changes in persons with low back pain and elderly persons during upright standing. Neurosci Lett. 2004;366(1):63-66. 
26. Braga AB, Rodrigues AC de MA, de Lima GVMP, de Melo LR, de Carvalho AR, Bertolini GRF. Comparison of static postural balance between healthy subjects and those with low back pain. Acta Ortop Bras. 2012;20(4):210-212.

27. Yodchaisarn W, Puntumetakul R, Emasithi A, Boucaut R, Chatchawan U. Altered postural sway during quiet standing in women with clinical lumbar instability. $J$ Phys Ther Sci. 2018;30(8):1099-1102.

28. Janssens L, McConnell AK, Pijnenburg M, et al. Inspiratory muscle training affects proprioceptive use and low back pain. Med Sci Sports Exerc. 2015;47(1):12-19.

29. Ringheim I, Austein H, Indahl A, Roeleveld K. Postural strategy and trunk muscle activation during prolonged standing in chronic low back pain patients. Gait Posture. 2015;42(4):584-589.

30. Brumagne S, Janssens L, Janssens E, Goddyn L. Altered postural control in anticipation of postural instability in persons with recurrent low back pain. Gait Posture. 2008;28(4):657-662.

31. Lafond D, Champagne A, Descarreaux M, Dubois J-D, Prado JM, Duarte M. Postural control during prolonged standing in persons with chronic low back pain. Gait Posture. 2009;29(3):421-427.

32. Liao C-F, Lin S-I. Effects of different movement strategies on forward reach distance. Gait Posture. 2008;28(1):16-23.

33. Tantisuwat A, Chamonchant D, Boonyong S. Multi-directional Reach Test: An Investigation of the Limits of Stability of People Aged between 20-79 Years. $J$ Phys Ther Sci. 2014;26(6):877-880.

34. Lynch SM, Leahy P, Barker SP. Reliability of measurements obtained with a modified functional reach test in subjects with spinal cord injury. Phys Ther. 1998;78(2):128-133.

35. Field-Fote EC, Ray SS. Seated reach distance and trunk excursion accurately reflect dynamic postural control in individuals with motor-incomplete spinal cord injury. Spinal Cord. 2010;48(10):745-749.

36. Thompson M, Medley A. Forward and lateral sitting functional reach in younger, middle-aged, and older adults. J Geriatr Phys Ther. 2007;30(2):43-48.

37. Ki C, Heo M, Kim H-Y, Kim E-J. The effects of forced breathing exercise on the lumbar stabilization in chronic low back pain patients. J Phys Ther Sci. 2016;28(12):3380-3383. 
38. Lee H-J, Kang T-W, Kim B-R. Effects of diaphragm and deep abdominal muscle exercise on walking and balance ability in patients with hemiplegia due to stroke. J Exerc Rehabil. 2018;14(4):648-653.

39. Ferraro F V., Gavin JP, Wainwright T, McConnell A. The effects of 8 weeks of inspiratory muscle training on the balance of healthy older adults: a randomized, double-blind, placebo-controlled study. Physiol Rep. 2019;7(9):e14076.

40. Dülger E, Bilgin S, Bulut E, et al. The effect of stabilization exercises on diaphragm muscle thickness and movement in women with low back pain. $J$ Back Musculoskelet Rehabil. 2018;31(2):323-329.

41. Foster NE, Anema JR, Cherkin D, et al. Prevention and treatment of low back pain: evidence, challenges, and promising directions. Lancet. March 2018.

42. Huskisson E. MEASUREMENT OF PAIN. Lancet. 1974;304(7889):1127-1131.

43. Hawker GA, Mian S, Kendzerska T, French M. Measures of adult pain: Visual Analog Scale for Pain (VAS Pain), Numeric Rating Scale for Pain (NRS Pain), McGill Pain Questionnaire (MPQ), Short-Form McGill Pain Questionnaire (SFMPQ), Chronic Pain Grade Scale (CPGS), Short Form-36 Bodily Pain Scale (SF. Arthritis Care Res (Hoboken). 2011;63(S11):240-252.

44. Kiesel KB, Uhl TL, Underwood FB, Rodd DW, Nitz AJ. Measurement of lumbar multifidus muscle contraction with rehabilitative ultrasound imaging. Man Ther. 2007;12(2):161-166.

45. Wallwork TL, Stanton WR, Freke M, Hides JA. The effect of chronic low back pain on size and contraction of the lumbar multifidus muscle. Man Ther. 2009;14(5):496-500.

46. Svantesson U, Herbert-Losier K, Wessman C, Alricsson M. The standing heel-rise test: reference values and test-retest reliability for healthy individuals from 20 to 81 years of age. Physiotherapy. 2015;101:e1458.

47. Rankin G, Stokes M, Newham DJ. Abdominal muscle size and symmetry in normal subjects. Muscle Nerve. 2006;34(3):320-326.

48. Harper CJ, Shahgholi L, Cieslak K, Hellyer NJ, Strommen JA, Boon AJ. Variability in diaphragm motion during normal breathing, assessed with B-mode ultrasound. J Orthop Sports Phys Ther. 2013;43(12):927-931.

49. Kiesel KB, Uhl TL, Underwood FB, Rodd DW, Nitz AJ. Measurement of lumbar multifidus muscle contraction with rehabilitative ultrasound imaging. Man Ther. 2007;12(2):161-166. 
50. Sclauser Pessoa IMB, Franco Parreira V, Fregonezi GAF, Sheel AW, Chung F, Reid WD. Reference values for maximal inspiratory pressure: a systematic review. Can Respir J. 2014;21(1):43-50.

51. Tudorache V, Oancea C, Mlădinescu OF. Clinical relevance of maximal inspiratory pressure: determination in COPD exacerbation. Int J Chron Obstruct Pulmon Dis. 2010;5:119-123.

52. Kim M, Lee K, Cho J, Lee W. Diaphragm Thickness and Inspiratory Muscle Functions in Chronic Stroke Patients. Med Sci Monit. 2017;(23):1247-1253.

53. Pupišová Z, Pupiš M, Jančoková L, Pivovarniček P. Changes of Inspiratory Parameters and Swimming Performance by Influence of Powerbreathe Plus Level 3. Sport Science. 2014(2): 12-15

54. Volianitis S, McConnell AK, Jones DA. Assessment of Maximum Inspiratory Pressure. Respiration. 2001;68(1):22-27.

55. Altman P, Wehbe L, Dederichs J, et al. Comparison of peak inspiratory flow rate via the Breezhaler ${ }^{\circledR}$, Ellipta ${ }^{\circledR}$ and HandiHaler ${ }^{\circledR}$ dry powder inhalers in patients with moderate to very severe COPD: a randomized cross-over trial. BMC Pulm Med. 2018;18(1):100.

56. O’Sullivan PB, Grahamslaw KM, Kendell M, Lapenskie SC, Möller NE, Richards $\mathrm{K} \mathrm{V}$. The effect of different standing and sitting postures on trunk muscle activity in a pain-free population. Spine (Phila Pa 1976). 2002;27(11):1238-1244.

57. Zhang S, Xu Y, Han X, Wu W, Tang Y, Wang C. Functional and Morphological Changes in the Deep Lumbar Multifidus Using Electromyography and Ultrasound. Sci Rep. 2018;8(1):6539.

58. Fortin M, Macedo LG. Multifidus and Paraspinal Muscle Group Cross-Sectional Areas of Patients With Low Back Pain and Control Patients: A Systematic Review With a Focus on Blinding. Phys Ther. 2013;93(7):873-888.

59. O'Sullivan P. Common misconceptions about back pain in sport: Tiger Woods' case brings five fundamental questions into sharp focus. $\mathrm{Br} J$ Sports Med. 2015;49(14):905-907.

60. Koppenhaver S, Harris D, Harris A, et al. The reliability of rehabilitative ultrasound imaging in the measurement of infraspinatus muscle function in the symptomatic and asymptomatic shoulders of patients with unilateral shoulder impingement syndrome. Int J Sports Phys Ther. 2015;10(2):128-135. 
61. Hodges PW, Cholewicki J, Van Dieën JH. Spinal control: the rehabilitation of back pain : state of the art and scienceSpinal Control: The Rehabilitation of Back Pain : State of the Art and Science. Physiother Can. 2015; 67(4): 394.2013.

62. Langevin HM, Sherman KJ. Pathophysiological model for chronic low back pain integrating connective tissue and nervous system mechanisms. Med Hypotheses. 2007;68(1):74-80

63. Lederman E. The myth of core stability. J Bodyw Mov Ther. 2010;14(1):84-98.

64. McCaskey MA, Schuster-Amft C, Wirth B, Suica Z, de Bruin ED. Effects of proprioceptive exercises on pain and function in chronic neck- and low back pain rehabilitation: a systematic literature review. BMC Musculoskelet Disord. 2014;15:382.

65. Floyd WF, Silver PHS. The Function of the Erectores Spinae Muscles in Certain Movements and Postures in Man. J Physiol. 1955;129(1): 184-203.

66. Sweeney N, O’Sullivan C, Kelly G. Multifidus muscle size and percentage thickness changes among patients with unilateral chronic low back pain (CLBP) and healthy controls in prone and standing. Man Ther. 2014;19(5):433-439.

67. Claeys K, Brumagne S, Dankaerts W, Kiers H, Janssens L. Decreased variability in postural control strategies in young people with non-specific low back pain is associated with altered proprioceptive reweighting. Eur J Appl Physiol. 2011;111(1):115-123.

68. Willson JD, Dougherty CP, Ireland ML, Davis IM. Core Stability and Its Relationship to Lower Extremity Function and Injury. J Am Acad Orthop Surg. 2005;13(5):316-325.

69. Linek P, Saulicz E, Wolny T, Myśliwiec A. Body Mass Normalization for Ultrasound Measurements of Adolescent Lateral Abdominal Muscle Thickness. J Ultrasound Med. 2017;36(4):775-782.

70. Vasconcelos T, Hall A, Viana R. The influence of inspiratory muscle training on lung function in female basketball players - a randomized controlled trial. Porto Biomed J. 2017;2(3):86-89.

71. Williamson A, Mbbs BH. Issues in Clinical Nursing Pain: A Review of Three Commonly Used Pain Rating Scales. J Clin Nurs. 2005;14(7):798-804.

72. Feuerstein M, Beattie PF. Biobehavioral Factors Affecting Pain and Disability in Low Back Pain: Mechanisms and Assessment. Phys Ther. 1995;75(4):267-80. 
73. Dellve L, Ahlstrom L, Jonsson A, et al. Myofeedback training and intensive muscular strength training to decrease pain and improve work ability among female workers on long-term sick leave with neck pain: a randomized controlled trial. Int Arch Occup Environ Health. 2011;84(3):335-346.

74. Bonica JJ. Management of Myofascial Pain Syndromes in General Practice. J Am Med Assoc. 1957;164(7):732.

75. Akbari A, Khorashadizadeh S, Abdi G. The Effect of Motor Control Exercise versus General Exercise on Lumbar Local Stabilizing Muscles Thickness: Randomized Controlled Trial of Patients with Chronic Low Back Pain. Journal of Back and Musculoskeletal Rehabilitation. (2008;(21)105-112

76. Lima PO de P, de Oliveira RR, de Moura Filho AG, Raposo MCF, Costa LOP, Laurentino GEC. Reproducibility of the pressure biofeedback unit in measuring transversus abdominis muscle activity in patients with chronic nonspecific low back pain. J Bodyw Mov Ther. 2012;16(2):251-257.

77. Storheim K, Bø K, Pederstad O, Jahnsen R. Intra-tester reproducibility of pressure biofeedback in measurement of transversus abdominis function. Physiother Res Int. 2002;7(4):239-249.

78. Rasouli O, Arab AM, Amiri M, Jaberzadeh S. Ultrasound measurement of deep abdominal muscle activity in sitting positions with different stability levels in subjects with and without chronic low back pain. Man Ther. 2011;16(4):388-393.

79. Hodges PW. Is there a role for transversus abdominis in lumbo-pelvic stability? Man Ther. 1999;4(2):74-86.

80. Yates JW, Karwowski W. An electromyographic analysis of seated and standing lifting tasks. Ergonomics. 1992;35(7-8):889-898.

81. Moseley GL, Hodges PW, Gandevia SC. Deep and Superficial Fibers of the Lumbar Multifidus Muscle Are Differentially Active During Voluntary Arm Movements. Spine (Phila Pa 1976). 2002;27(2):29-36.

82. Kolar P, Neuwirth J, Sanda J, et al. Analysis of diaphragm movement during tidal breathing and during its activation while breath holding using MRI synchronized with spirometry. Physiol Res. 2009;58(3):383-392.

83. Dülger E, Bilgin S, Bulut E, et al. The effect of stabilization exercises on diaphragm muscle thickness and movement in women with low back pain. J Back Musculoskelet Rehabil. 2018;31(2):323-329. 
84. Macintosh JE, Bogduk N. The biomechanics of the lumbar multifidus. Clin Biomech. 1986;1(4):205-213.

85. Li KW, Wang CW, Yu R. Modeling of predictive muscular strength for sustained one-handed carrying task. Work. 2015;52(4):911-919.

86. Kim E, Lee H. The effects of deep abdominal muscle strengthening exercises on respiratory function and lumbar stability. J Phys Ther Sci. 2013;25(6):663-665.

87. Hodges P, Kaigle Holm A, Holm S, et al. Intervertebral Stiffness of the Spine Is Increased by Evoked Contraction of Transversus Abdominis and the Diaphragm: In Vivo Porcine Studies. Spine (Phila Pa 1976). 2003;28(23):2594-2601.

88. Cholewicki J, Ivancic P, Radebold A. Can increased intra-abdominal pressure in humans be decoupled from trunk muscle co-contraction during steady state isometric exertions? Eur J Appl Physiol. 2002;87(2):127-133.

89. Rezkallah SF, Abd El-Hady AA, Fatma ;, Hamid A, Botros FF. Sonographic Response of Diaphragmatic Excursion to Threshold Inspiratory Muscle Trainer in Elderly. Med. J. Cairo Univ. 2017;(85)541-545.

90. Haytham H.M., Azza A.E., Mohamed E.s. NEG. Response of Diaphragmatic Excursion to Inspiratory Muscle Trainer Post Thoracotomy. Int J Med Heal Sci. 2016;10(1):15-18.

91. Caron O, Fontanari P, Cremieux J, Joulia F. Effects of ventilation on body sway during human standing. Neurosci Lett. 2004;366(1):6-9.

92. Michał Kuczyński, and, Marcin Wieloch1. Effects of Accelerated Breathing On Postural Stability. Hum Mov. 2009;9(2):107-110.

93. Hodges PW, Gurfinkel VS, Brumagne S, Smith TC, Cordo PC. Coexistence of stability and mobility in postural control: evidence from postural compensation for respiration. Exp Brain Res. 2002;144(3):293-302.

94. Robinson EP, Kjeldgaard JM. Improvement in ventilatory muscle function with running. J Appl Physiol. 1982;52(6):1400-1406.

95. Silfies SP, Bhattacharya A, Biely S, Smith SS, Giszter S. Trunk control during standing reach: A dynamical system analysis of movement strategies in patients with mechanical low back pain. Gait Posture. 2009;29(3):370-376.

96. Kodric M, Trevisan R, Torregiani C, et al. Inspiratory muscle training for diaphragm dysfunction after cardiac surgery. J Thorac Cardiovasc Surg. 2013;145(3):819-823. 
97. Panjabi MM. The stabilizing system of the spine. Part II. Neutral zone and instability hypothesis. J Spinal Disord. 1992;5(4):390-6.

98. Gandevia SC, McKenzie DK. Activation of the human diaphragm during maximal static efforts. J Physiol. 1985;367:45-56. doi:10.1113/jphysiol.1985.sp015813

99. Wong AYL, Parent EC, Funabashi M, Stanton TR, Kawchuk GN. Do various baseline characteristics of transversus abdominis and lumbar multifidus predict clinical outcomes in nonspecific low back pain? A systematic review. PAIN®. 2013;154(12):2589-2602.

100. Shumway-Cook A, Woollacott MH. Motor Control: Translating Research into Clinical Practice. Lippincott Williams \& Wilkins; 2012. Fourth, North American edition, Philadelphia. 


\section{Appendix}

\subsection{Supplementary materials of measurements and training sections}

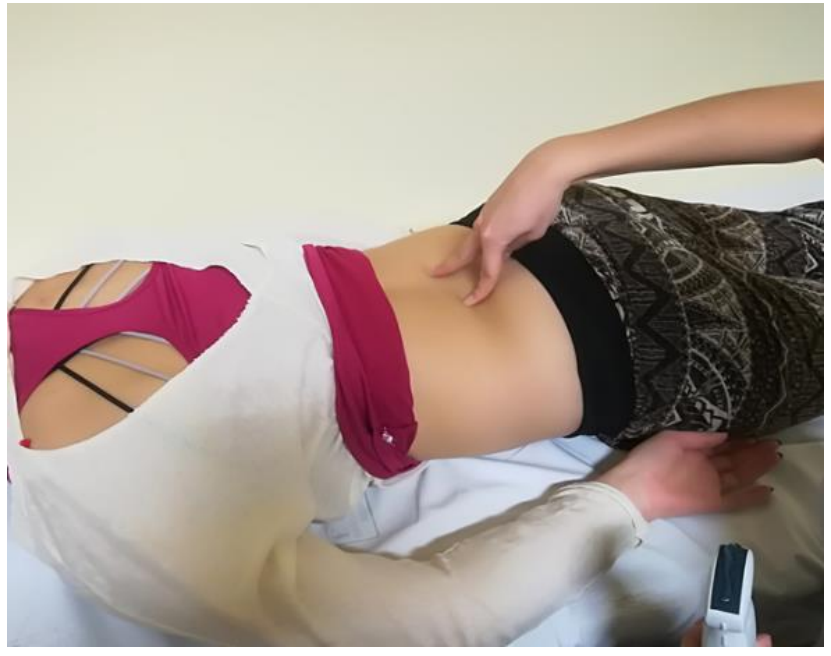

Figure 1: The applied triggering design to enhance the contraction of multifidus muscle

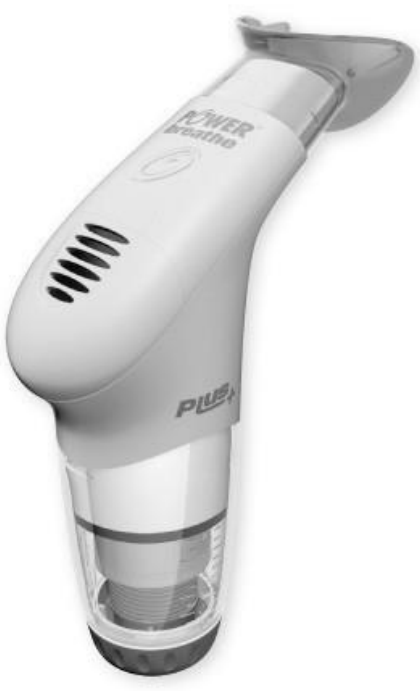

Figure 3: POWERbreathe Medic Plus device

Forrás:

https://www.google.com/search?q=powerbreathe+medic+plus\&safe=off\&rlz=1C1AVNE_enHU679HU679\&sxsrf=ACYBGNRsK YNYogtkwEayE7iZ2ugPaZpzzw:1568123063180\&source=lnms\&tbm=isch\&sa=X\&ved=0ahUKEwjc_ZPRscbkAhVmxIsKHVkQ AEAQ_AUIEigB\&biw=1366\&bih=614\#imgrc=5OqEQSK3qc_q0M: 

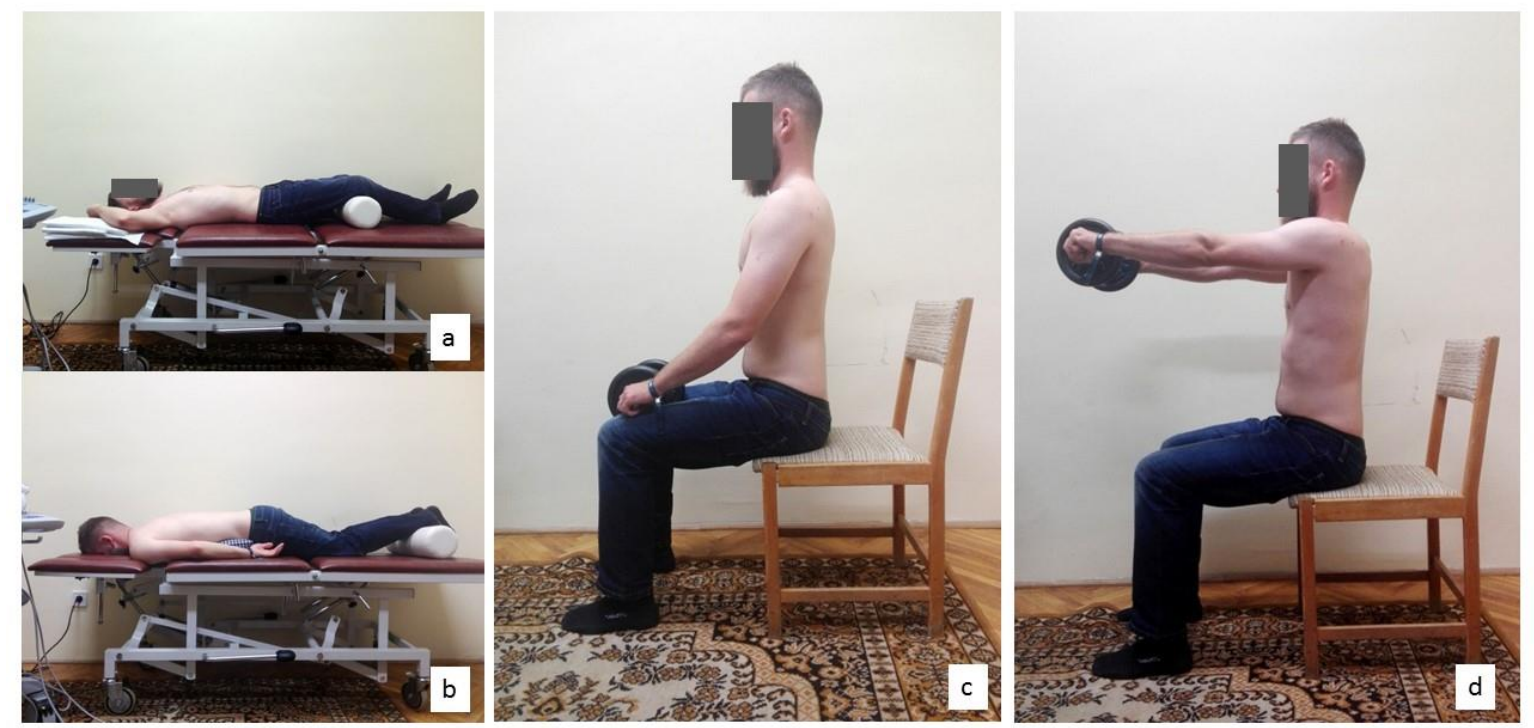

Figure 4: The applied postures during the ultrasonography: $a$, supine position; $b$, prone position; $c$, quiet sitting; $d$, weightlifting
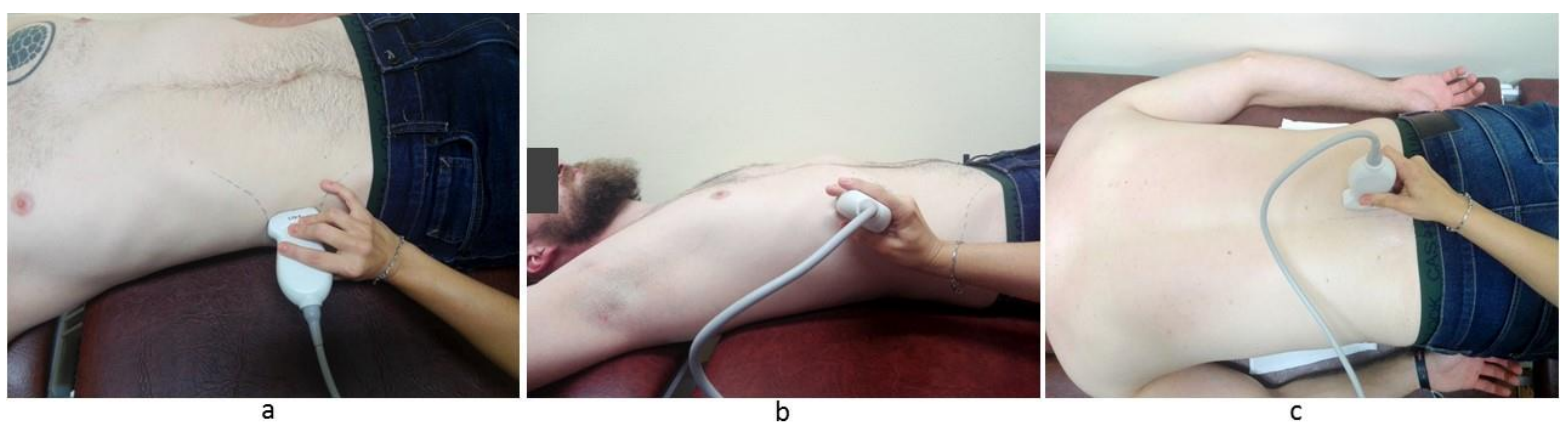

Figure 5: The positions of the transducers: a, transversus abdominis muscle; $b$, diaphragm muscle; c, lumbar multifidus muscle (right-sided). 


\section{The details of the conventional training program}

The conventional training can be divided into 3 parts: a warm-up, a main part and a cool down section.

1. Warm-up: the training started with a 10 min warm-up section. The warm-up contained breathing exercises and dynamic exercises for all joints and muscles in standing position.

2. The main part: the training method was a circuit training with five sections and with $3 \mathrm{~min}$ of exercising in one section, altogether in $40 \mathrm{~min}$ duration. There were 1 min breaks between the sections while the participants took their places at the next section.

$1^{\text {st }}$. section: Strengthening exercises of the hip muscles:

Combined static and dynamic strengthening of the hip muscles

$2^{\text {nd }}$. section: Balancing exercise:

Static balance exercises (holding a position) on an unstable training tool in vertical posture (standing, kneeling)

$3^{\text {rd. }}$ section: Strengthening exercises of the extensor muscles of the trunk:

Combined static and dynamic strengthening of extensors using limb activities with dynamic resistance

$4^{\text {th }}$ section: Strengthening exercise of the abdominal muscles:

Combined static and dynamic strengthening of abdominal muscles using limb activities with dynamic resistance

$5^{\text {th }}$ section: Balancing exercise:

Dynamic reactive balance exercises: walking on unstable surfaces.

3. Cool down: the training ended with a cool-down section in 10 min duration.

This part of the training contained light aerobic, stretching and breathing exercises.

\subsection{Supplementary materials of the results section}

Table 4: The results of the statistical comparison. $* P<0.05 ; * * P<0.01$ (Abbreviations:

C: control, DT: diaphragm training) 


\begin{tabular}{|c|c|c|c|c|c|c|c|c|}
\hline \multicolumn{4}{|c|}{ group $C(n=21)$} & $\begin{array}{c}P \text { after } \\
\text { Bonferroni-Holm }\end{array}$ & mean & SE & $\begin{array}{l}\text { group DT (n: } \\
\boldsymbol{P} \text { (ANOVA) }\end{array}$ & $\begin{array}{l}P \text { after } \\
\text { Bonferroni-Holm }\end{array}$ \\
\hline \multicolumn{9}{|c|}{ Transversus abdominis_relaxed state } \\
\hline $\begin{array}{l}\text { before } \\
\text { after }\end{array}$ & $\begin{array}{l}0,280 \\
0,311\end{array}$ & $\begin{array}{l}0,017 \\
0,019\end{array}$ & $0,018^{*}$ & 0,320 & $\begin{array}{l}0,307 \\
0,343\end{array}$ & $\begin{array}{l}0,018 \\
0,018\end{array}$ & $0,002 * *$ & $0,041^{*}$ \\
\hline \multicolumn{9}{|c|}{ Transversus abdominis_contracted state } \\
\hline $\begin{array}{l}\text { before } \\
\text { after }\end{array}$ & $\begin{array}{l}0,607 \\
0,707\end{array}$ & $\begin{array}{l}0,031 \\
0,054\end{array}$ & $0,012^{*}$ & 0,243 & $\begin{array}{l}0,633 \\
0,737\end{array}$ & $\begin{array}{l}0,037 \\
0,047\end{array}$ & $0,004 * *$ & 0,092 \\
\hline \multicolumn{9}{|c|}{ Transversus abdominis_relatively relaxed state } \\
\hline $\begin{array}{l}\text { before } \\
\text { after }\end{array}$ & $\begin{array}{l}0,381 \\
0,408\end{array}$ & $\begin{array}{l}0,022 \\
0,048\end{array}$ & 0,538 & 1 & $\begin{array}{l}0,419 \\
0,514\end{array}$ & $\begin{array}{l}0,040 \\
0,049\end{array}$ & $0,000 * *$ & $0,003^{* *}$ \\
\hline \multicolumn{9}{|c|}{ Transversus abdominis_relatively contracted state } \\
\hline $\begin{array}{l}\text { before } \\
\text { after }\end{array}$ & $\begin{array}{l}0,466 \\
0,565\end{array}$ & $\begin{array}{l}0,031 \\
0,082\end{array}$ & 0,174 & 1 & $\begin{array}{l}0,488 \\
0,555\end{array}$ & $\begin{array}{l}0,051 \\
0,057\end{array}$ & $0,042^{*}$ & 0,712 \\
\hline \multicolumn{9}{|c|}{ Diaphragm_relaxed state } \\
\hline $\begin{array}{l}\text { before } \\
\text { after }\end{array}$ & $\begin{array}{l}0,127 \\
0,131\end{array}$ & $\begin{array}{l}0,010 \\
0,009\end{array}$ & 0,414 & 1 & $\begin{array}{l}0,131 \\
0,155\end{array}$ & $\begin{array}{l}0,008 \\
0,010\end{array}$ & $0,001 * *$ & $0,016 *$ \\
\hline \multicolumn{9}{|c|}{ Diaohragm_contracted state } \\
\hline $\begin{array}{l}\text { before } \\
\text { After }\end{array}$ & $\begin{array}{l}0,162 \\
0,170\end{array}$ & $\begin{array}{l}0,012 \\
0,017\end{array}$ & 0,550 & 1 & $\begin{array}{l}0,141 \\
0,225\end{array}$ & $\begin{array}{l}0,009 \\
0,016\end{array}$ & $0,000 * *$ & $0 * *$ \\
\hline Diaphragr & relativ & $y$ relax & state & & & & & \\
\hline $\begin{array}{l}\text { before } \\
\text { after }\end{array}$ & $\begin{array}{l}0,192 \\
0,173\end{array}$ & $\begin{array}{l}0,013 \\
0,014\end{array}$ & $0,012^{*}$ & 0,243 & $\begin{array}{l}0,178 \\
0,181\end{array}$ & $\begin{array}{l}0,009 \\
0,010\end{array}$ & 0,728 & 1 \\
\hline Diaphragr & _relativ & y contr & ted state & & & & & \\
\hline $\begin{array}{l}\text { before } \\
\text { after }\end{array}$ & $\begin{array}{l}0,206 \\
0,205\end{array}$ & $\begin{array}{l}0,017 \\
0,018\end{array}$ & 0,970 & 1 & $\begin{array}{l}0,176 \\
0,223\end{array}$ & $\begin{array}{l}0,011 \\
0,013\end{array}$ & $0,000 * *$ & $0,001^{* *}$ \\
\hline Lumbar m & Itifidus_ & ight sic & d)_relaxed st & & & & & \\
\hline $\begin{array}{l}\text { before } \\
\text { after }\end{array}$ & $\begin{array}{l}2,456 \\
2,524\end{array}$ & $\begin{array}{l}0,089 \\
0,178\end{array}$ & 0,635 & 1 & $\begin{array}{l}2,509 \\
2,601\end{array}$ & $\begin{array}{l}0,107 \\
0,107\end{array}$ & $0,045^{*}$ & 0,717 \\
\hline Lumbar m & Itifidus & ight sic & d)_contracte & ;tate & & & & \\
\hline $\begin{array}{l}\text { before } \\
\text { after }\end{array}$ & $\begin{array}{l}3,349 \\
3,458\end{array}$ & $\begin{array}{l}0,100 \\
0,187\end{array}$ & 0,466 & 1 & $\begin{array}{l}3,185 \\
3,253\end{array}$ & $\begin{array}{l}0,132 \\
0,129\end{array}$ & 0,313 & 1 \\
\hline Lumbar m & Itifidus_ & eft side & _relaxed sta & & & & & \\
\hline $\begin{array}{l}\text { before } \\
\text { after }\end{array}$ & $\begin{array}{l}2,363 \\
2,447\end{array}$ & $\begin{array}{l}0,079 \\
0,190\end{array}$ & 0,595 & 1 & $\begin{array}{l}2,352 \\
2,554\end{array}$ & $\begin{array}{l}0,090 \\
0,109\end{array}$ & $0,000 * *$ & $0,004^{* *}$ \\
\hline Lumbar m & Itifidus & eft side & _contracted & & & & & \\
\hline $\begin{array}{l}\text { before } \\
\text { after }\end{array}$ & $\begin{array}{l}3,337 \\
3,449\end{array}$ & $\begin{array}{l}0,092 \\
0,191\end{array}$ & 0,468 & 1 & $\begin{array}{l}3,155 \\
3,318\end{array}$ & $\begin{array}{l}0,116 \\
0,131\end{array}$ & $0,011^{*}$ & 0,228 \\
\hline Lumbar m & Itifidus_ & ight sic & d)_relatively & axed state & & & & \\
\hline $\begin{array}{l}\text { before } \\
\text { after }\end{array}$ & $\begin{array}{l}2,494 \\
2,627\end{array}$ & $\begin{array}{l}0,071 \\
0,157\end{array}$ & 0,326 & 1 & $\begin{array}{l}2,339 \\
2,470\end{array}$ & $\begin{array}{l}0,086 \\
0,082\end{array}$ & $0,005 * *$ & 0,099 \\
\hline Lumbar m & Itifidus & ight sic & d)_relatively & ntracted state & & & & \\
\hline $\begin{array}{l}\text { before } \\
\text { after }\end{array}$ & $\begin{array}{l}3,059 \\
3,118\end{array}$ & $\begin{array}{l}0,098 \\
0,210\end{array}$ & 0,723 & 1 & $\begin{array}{l}2,670 \\
2,873\end{array}$ & $\begin{array}{l}0,115 \\
0,110\end{array}$ & $0,002 * *$ & $0,046^{*}$ \\
\hline Lumbar m & Itifidus & eft side & relatively re & xed state & & & & \\
\hline $\begin{array}{l}\text { before } \\
\text { after }\end{array}$ & $\begin{array}{l}2,544 \\
2,684\end{array}$ & $\begin{array}{l}0,077 \\
0,177\end{array}$ & 0,347 & 1 & $\begin{array}{l}2,316 \\
2,474\end{array}$ & $\begin{array}{l}0,102 \\
0,094\end{array}$ & $0,002 * *$ & $0,044^{*}$ \\
\hline Lumbar m & ifidus & eft side & relatively c & racted state & & & & \\
\hline $\begin{array}{l}\text { before } \\
\text { after }\end{array}$ & $\begin{array}{l}3,142 \\
3,168\end{array}$ & $\begin{array}{l}0,143 \\
0,146\end{array}$ & 0,673 & 1 & $\begin{array}{l}2,624 \\
2,833\end{array}$ & $\begin{array}{l}0,126 \\
0,106\end{array}$ & $0,001 * *$ & $0,039 *$ \\
\hline
\end{tabular}


Table 5: Results of the statistical comparison.

Abbreviations: DT: diaphragm training; C: control; MIP: maximal inspiratory pressure; PIF: peak inspiratory flow; mFRT: modified Functional Reach Test; mLRT: modified Lateral Reach Test; SE: standard error

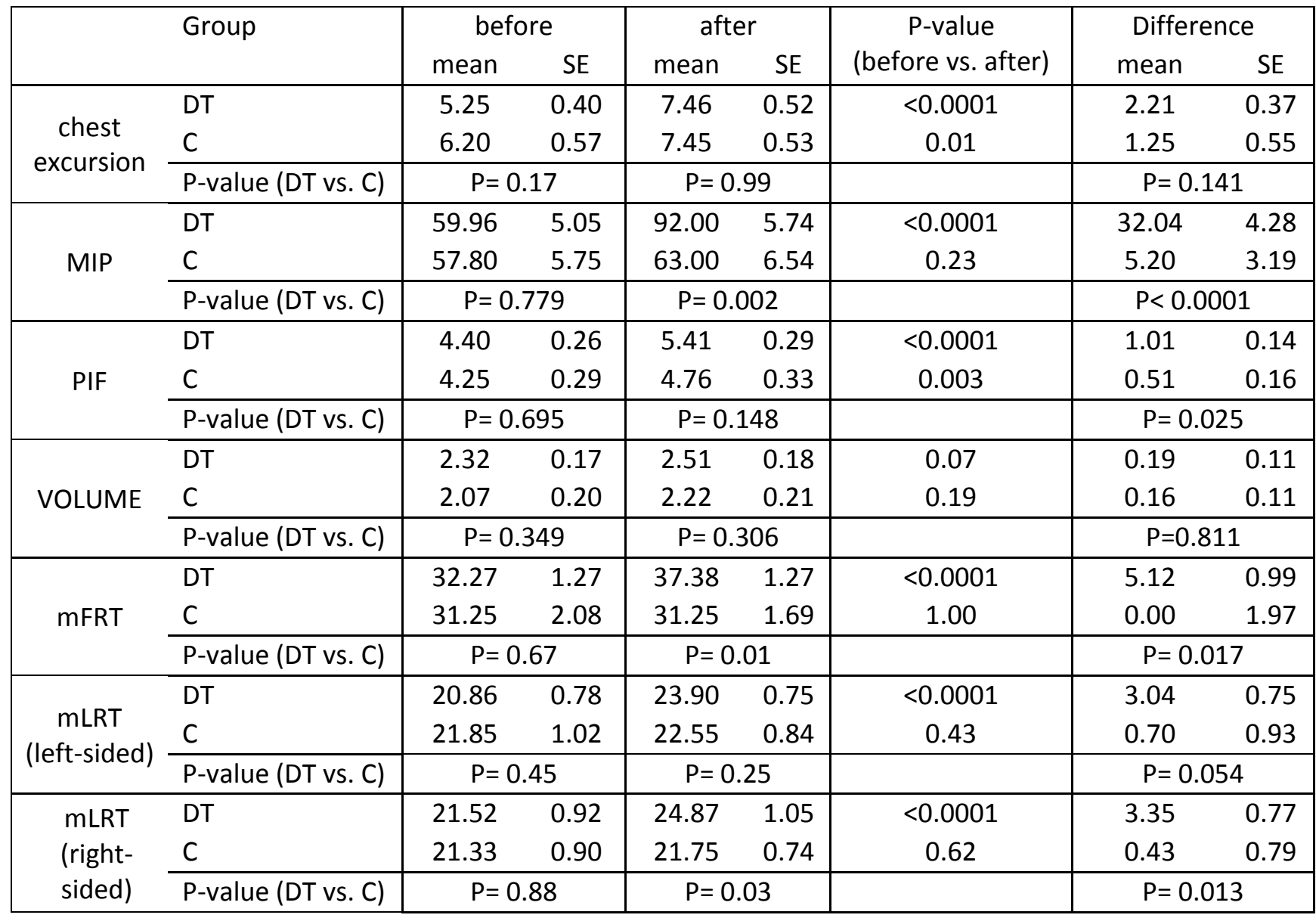




\title{
A diaphragma müködésében bekövetkezö változások és a derékfájdalom összefüggései, fizioterápiás kezelési lehetöségek
}

\author{
Finta Regina, Dr. Bender Tamás
}

\section{Bevezetés}

A derékfájdalom (low back pain, LBP), vagy más szóval lumbágó a bordavonal és a gluteális tájék között érzett fájdalom, vagy diszkomfort érzet, mely a combokba sugározhat (1). A krónikus derékfájdalmak nagy számban érintik minden korosztály tagjait, rendkivül gyakori panasz, az európai népesség 23\%-a tapasztalja meg az élete során (2). A hosszan fennálló fájdalom megnehezíti a hétköznapi feladatok elvégzését, a munkát, illetve negativ hatással lehet a rekreációs tevékenységekre, mindezzel befolyásolhatja a szociális kapcsolatokat is. A LBP lehetséges oka a nem megfeleló izomreakció és izomegyensúly, melynek alapja a rossz propriocepció (3) és többek között okozhatja a lumbális gerinc szegmentális instabilitása (4). A LPB fennállásakor az izmok mũködése eltérést mutathat, egy úgynevezett izom diszbalansz jöhet létre, mely hosszú távon további károsodások kialakulását segitheti elö. A törzs stabilitása lényegesen meghatározza a mozgások során fellépó erő́ket, melyek a megfelelŏ kompenzációs mechanizmusok hiányában károsithatják az izületeket. A károsító erōk csökkentésének, azaz a stabilitás megteremtésének érdekében stabilizátor izmok bekapcsolódása szükséges, melyek hosszan tartó túlterhelésre fokozott feszüléssel reagálhatnak. Amennyiben ezek az izmok nem tudják a kellŏ stabilitást megteremteni, úgy az izületek egyéb alkotóira hárul a feladat (5).

\section{Lumbális stabilitás}

A gerinc stabilitása három pilléren nyugszik, melyek maga a gerinc, a gerinc körül elhelyezkedó izmok és az ezeket vezérlö idegrendszeri szabályozás (4). A gerinc mozgásainak létrehozása mellett az izmoknak tehát fontos szerepük van a szegmentek stabilizálásában is. Alapvetǒen megkülönböztetünk szegmentális stabilizátor izmokat, illetve globális, több izületet áthidaló izmokat, melyek együttes müködésükkel játszanak alapvetổ szerepet a lumbális gerinc stabilitásának megörzésében (6). A m. transversus abdominis jelentösége régóta ismert az irodalomban. Több kutatás is beszámolt arról, hogy a különbözố végtagi mozgások elött a $m$. transversus abdominis kontrakcióba kell, hogy kerüljön egészséges mozgásszabályozás esetén $(6,7)$. Jól ismert, hogy a $\mathrm{m}$. multifidus részvétele szintén alapvetố a lumbális szegmentek stabilizálásában. Ezen izmok kapcsolatban vannak a thoraco-lumbális fasciával, melyre tónusuk növelésével hatnak, ami által a két oldali spina iliaca posterior superior közötti fascia feszessége fokozódik. Ez a mediális irányú erố a sacroiliacalis izületen keresztül stabilizálja a medencét. Egy korábbi tanulmányból kiderül, hogy a globális izmok, mint a m. gluteus maximus és a m. latissimus dorsi, a thoraco-lumbális fasciával való kapcsolatuk miatt képesek segiteni a stabilitást és egyben az alsó- és felsóvégtagok közötti kapcsolatot megteremteni. Ezen izmok kontrakciojukkal megfeszitik a thoraco-lumbalis fasciát, melynek feszessége egy rendkivül fontos tényezổ 
a lumbális gerinc stabilitásának tekintetében (6). Ezen funkcionális anatómiai tanulmány is alátámasztja azt a nézetet, mely szerint az ágyéki gerinc stabilitásáért nem egy izom, vagy izomcsoport felelós kizárólagosan $(8,9)$.

\section{Izomdiszbalansz derékfájdalom során}

LBP hatására számos változás bekövetkezik az izomzat állapotában, valamint a motoros szabályozásban, mely érinti a szegmentális és globális stabilizátorokat is. Alapvetôen megváltozik a derékfájdalommal küzdỏ egyéneknél az adott mozgás kivitelezéséhez szükséges motoros stratégia (11). Ezen változások az izmok funkcióit tekintve vizsgálhatók többek között EMG-vel, MRl-vel és diagnosztikus ultrahang segitségével is.

Ismert tény, hogy a krónikus fájdalom képes befolyásolni a mozgásunkat, tartásunkat és képes elváltozásokat létrehozni az izmok szintjén, azonban egy tanulmányban kimutatták, hogy már akut fájdalom is változásokat idéz elõ a motoros szabályozásban. A kutatók a jobb oldali longissimus dorsi izomzatba injekcióztak hipertóniás, illetve izotóniás oldatot. A fájdalom intenzitásának megítéléséhez Vizuál Analóg Skálát használtak. EMG segitségével a longissimus, a multifidus, rectus abdominis és obliquus externus abdominis izmokat vizsgálták törzs extenzió végrehajtásakor. Hipertóniás oldat injektálása után a fájdalom szignifikánsan magasabb volt az alanyoknál és a fájdalom hatására a rectus abdominis izomnak csökkent az aktivitása. Nagyon érdekes, hogy a mozgás szempontjából antagonista izom müködésében következett be változás (12). Egy másik kutatás hasonló eredményekre jutott, melynek során 10 perces elōrehajlás hatását vizsgálták. A kutatók a lumbális szakasz flexiójával a gerinc relativ instabil helyzetét kivánták kiváltani, az extensor izomzat relaxációja és a szalagok megnyújtása révén. Az alanyoknak a 10 perces flexió végrehajtása elött és után különbözó gyakorlatokat kellett kivitelezniük, közben felületi EMG-vel folyamatosan mérték a $\mathrm{m}$. rectus abdominis, a $\mathrm{m}$. obliquus externus abdominis (flexorok) és a m. erector spinae (extenzor) aktivitását. A vizsgálók arra a következtetésre jutottak, hogy a lumbális szakasz instabilitása elsösorban az antagonista izmok múködésést befolyásolta. Az antagonista co-contractio sérült a fokozott izületi instabilitás miatt, ami megváltoztatta a motoros szabályozást (13).

A m. transversus abdominis bekapcsolódása késve indul meg LBP esetén. Állás során vizsgálták a m. transversus abdominis múködését, miközben a derékfájdalommal küzdō és egészséges alanyoknak gyors vállizületi flexiót kellett végrehajtaniuk. A kutatás igazolta, hogy LBP esetén a $\mathrm{m}$. transversus abdominis nem elsốként lép be -megelózve a kar elmozdulását-, késve kezdi el a mũködését az egészséges alanyok eredményeivel összehasonlitva. A kutatók arra a következtetésre jutottak, hogy a $\mathrm{m}$. transversus abdominis múködésének változása a mozgásszabályozásban bekövetkezõ elváltozások következménye, mely hatására az izom stabilizáló funkciója sérül, igy a derékfájdalmat lumbális instabilitás is kiséri (8).

Az egyensúly megtartásának képessége minden mozgásunk során elengedhetetlen, azonban ez derékfájdalom hatására károsodhat. LBP fennállásakor a poszturális kontroll is érintetté válik, mely komoly stabilitási problémákat okozhat (14). Térdelö pozícióból féltérdelố helyzetbe kerülés során létrejövő izommǘködést vizsgálta egy tanulmány. 
A vizsgálatba középkorú nőket választottak be és állapotuk alapján beosztották ōket LBP és kontroll csoportba. A m. obliquus internus, a m. erector spinae és a m. gluteus medius izomhasára helyezték fel a felületi EMG elektródáit. A súlyáthelyezéssel és súlyviseléssel járó funkcionális feladatot a derékfájdalommal kūzdō alanyok a m. erector spinae fokozott aktivitásával és bekapcsolásával oldották meg, míg a kontroll csoport tagjai alapvetöen a has és csipõ körüli izmaikat használták a mozgás kivitelezéséhez (11).

Abboud és munkatársai 64 elvezetéses EMG-vel vizsgálták a m. erector spinae mũködését derékfájdalommal küzdōk és egészségesek körében. Az izom fáradását vizsgálták, törzsemelés végzése közben. A vizsgálatból kiderült, hogy a derékfájdalommal küzdök körében az izom fáradása hamarabb következett be (15).

\section{A diaphragma szerepe a lumbális stabilitásban}

A korábbiakban láthattuk tehát, hogy mind a globális, mint a szegmentális törzsstabilizátorok müködésében változások következnek be LBP hatására. Azonban nem csak a fentebb részletezett izmok felelösek a lumbális stabilitás fenntartásárt, a diaphragma szerepe is igen jelentös, összehúzódásával képes fokozni a hasüri nyomást $(15,16,17)$. A diaphragma elsôdleges légzési szerepét támasztja alá Hodges és munkatársainak vizsgálata, mely során arra jutottak, hogy amennyiben az idegrendszer a légzést fokozni kényszerül, csökkenti a rekesz részvételét a poszturális feladatokban (19). Egy korábbi vizsgálatuk azonban igazolja, hogy a diaphragma szerepe nem csak a légzésben alapvetô, hanem a lumbális gerinc stabilitásának megteremtésében is. A vizsgálat során arra találtak bizonyitékot a kutatók, hogy a diaphragma kontrakcióba kerül bizonyos mozgások elinditásának pillanata elô̄tt. Ezen kutatás során egészséges alanyoknak gyors kar emelést kellett végrehajtaniuk, miközben a diaphragma és a m. transversus abdominis mũködését vizsgálták EMG-vel. A mozgás kivitelezése közben a transz-diaphragmális, oesophagialis és a gastricus nyomást is mérték, a diaphragma mozgását diagnosztikus ultrahanggal követték. A vizsgálat során a kutatók azt találták, hogy a diaphragma a vállizületi flexió elindítása elōtt aktiválódott, a légzés állapotától függetlenül. A m. transversus abdominis is hamarabb aktiválódott, majdnem egyszerre a diaphragmával. A kutatás arra enged kōvetkeztetni, hogy a diaphragma szerepe a hasūri-nyomás fokozásában jelentōs a nagy felsõvégtagi mozgások kivitelezése során, a törzs stabilitásának biztosítása érdekében. Emellett a rekeszizom segit abban, hogy a hasüri szervek a hasizmok kontrakciójának hatására ne nyomódjanak a mellkas irányába, így azok az izmok képessé válnak a thoraco-lumbális fascia megfeszitésére és ezzel a lumbális gerinc stabilitásának fokozására (18). Poszturális funkcióját tekintve, szerepe tehát megegyezik a medencefenék izomzat és a m. transversus abdominis mũködésével, melyek különbözō mozgások során a hasūri nyomás fokozásában szintén részt vesznek, hogy támaszt biztositsanak a csigolyáknak a gerinc stabilitásának érdekében $(19,20)$. A rekeszizom -elhelyezkedését tekintve-közvetlen kapcsolatban van az ágyéki csigolyákkal és a m. transversus abdominisszel szinergizmusban müködik (22). A diaphragma, a m. transversus abdominis és a medencefenék izmok egyidejü, összehangolt kontrakciója a legfontosabb és alapvetố eleme a lumbális gerinc stabilitásának (23). 
Krónikus derékfájdalom esetén, azonban ezen izmok aktivációs mintázata együttesen megváltozik (24).

A rekeszizom eltéró mozgási mintázatát igazolja LBP esetén Kolár és munkatársainak kutatása. Krónikus derékfájdalommal küzdó és egészséges alanyok bevonásával végeztek dinamikus MRI-t és spirometriás vizsgálatot, mely során az egyéneknek izometriás vállizületi flexiót és kétoldali, izometriás csípöizūleti flexiót kellett végrehajtaniuk, háton fekvỏ helyzetben. A rekeszizom elülsố és középsố része csökkent mozgást mutatott az LBP csoport esetében, mig a hátulsó részének mozgása megegyezett a kontroll csoportéval, az egészséges alanyok rekeszizmának minden része szimmetrikusan mozgott. A kutatók azt gondolják, hogy a diaphragma abnormális poszturális aktivációja lehet a felelōs a LBP kialakulásáért (25). Érdekes, hogy nehéz tárgy földröl történō felemelését másképp kivitelezik a derékfájdalommal érintett egyének. Egy vizsgálat során a belégzési térfogatot mérték az egészséges és derékfájós alanyoknál, különbőzō súlyú tárgyak emelése kōzben. A fájdalommal küzdő egyének több levegōt lélegeztek be, összehasonlitva a panaszmentes résztvevőkkel. A kor elörehaladtával a derékfájós alanyok növelték a belélegzett levegő mennyiségét, mig az egészségesek csökkentették azt, a feladat kivitelezéséhez (26). A rekeszizom megváltozott múködése a poszturális kontroll eltéréseiben is megmutatkozik. A légzés fiziológiás müködése során a mozgó mellkas a testtömegközéppont helyzetének kitérését idézi elō, melyet az egészséges alanyok jobban képesek kompenzálni, mint a derékfájdalommal küzdōk, emellett a derékfájós egyének a csípő stratégiát is kevésbé használjảik az egyensúly megtartására (27). A rekeszizom fáradékonyabbá is válik LBP esetén. A derékfájdalommal küzdôk $80 \%$-ánál mérhetốk a fáradás jelei ellenállással szembeni belégzést követően, mig a panaszmentes alanyoknál ez az arány csupán 40\%-ra tehetỗ (28). Egy másik kutatásban egészséges és derékfájós egyéneket vizsgáltak ellenállással szemben végzett belégzési munka elött és után. A kutatók azt találták, hogy az egészséges alanyok a diaphragma fáradása után átváltanak egy rigid proprioceptív poszturális stratégiára, mellyel inkább a bokaizùletből származó proprioceptiv információkra hagyatkoznak, elhagyva a normál multiszegmentális stratégiát az egyensúlyuk megtartásához. A derékfájdalommal küzdô alanyok, azonban ugyanezt a rigid stratégiát használják a rekeszizom fáradása elōtt és azt követốen is. A kutatók úgy gondolják, hogy ez a stratégia a poszturális instabilitás következményeként alakul ki és lehetséges, hogy az izomfáradás az egyik kiváltó oka a derékfájdalom gyakori kiújulásának (29).

\section{Eltérö légzési mintázat és a derékfájdalom}

Fontos kiemelni, hogy a LBP és a légzési problémák összefüggéseit már több tanulmány is igyekezett feltárni és eredményeik alapján elmondható, hogy bizonyos légzési betegségek gyakran járnak egyưtt a deréktáji fájdalmakkal (30). A rekeszizom megváltozott mûködése alapjául szolgálhat különbözổ légzési betegségek kialakulásának, mely hatására a derékfájdalommal küzdốk esetében hiperventilláció és következményes hypocapnia is kialakulhat, befolyásolva ezzel az izomaktivitást (24). Bár a fizikai aktivitás hiánya és az obezitás gyakran együtt jár a derékfájdalommal (28), egy kérdōives felmérés során, mely- 
ben 14060 fiatal, 13004 középkorú és 10986 idôs nổ vett részt, fény derült arra, hogy a légzési elváltozások és az inkontinencia inkább korrelál az ágyéki gerinc panaszaival, mint az elhizás, vagy a rendszeres mozgás hiánya (31).

A diaphragma és a többi törzsstabilizátor érintettsége megfigyelhetô olyan egyéneknél, akiknél legalább három hónapja sacroiliacalis izületi fájdalom áll fenn. Ezen alanyoknál csökkent diaphragma mozgást, a medencefenék izomzat fokozott leereszkedését figyelték meg ultrahang segítségével, spirometriás vizsgálattal pedig igazolták a megváltozott légzési mintázatot. A fájdalommal érintett személyeknél a percventilláció növekedését és emelkedett légzési hányadost tapasztaltak (32). Ezeket az eredményeket alátámasztja Vostatek és munkatársainak kutatása, melyben a rekeszizom müködését MRI-vel vizsgálták, egészséges és derékfájdalommal küzdō alanyok diaphragma mozgását összehasonlitva, kūlönböző feladatok elvégzése során. A lumbágós egyéneknél magasabb légzési frekvenciát találtak és a diaphragma kisebb mértékũ mozgását (33).

Több szerző is egyetért abban, hogy a normál légzési minta helyreállitása elengedhetetlen derékfájdalom esetén $(33,34,35)$ és légzó gyakorlatokon keresztül a komplex törzsstabilizáló rendszerre közvetlenül hatni lehet (23).

\section{Kezelési lehetőségek}

Egy 2016-os tanulmányban azt vizsgálták, hogy milyen hatással lehet a háti gerinc mobilizáció a derékfájdalommal küzdő egyének légzésére, életminőségére. 62 derékfájdalommal küzdő egyént kezeltek 2 hétig, minden nap. A vizsgálati alanyokat két csoportra osztották, az egyik csoport egyéni, általános kezelést kapott a fájdalom csökkentésére és otthon is tornázott, mig a másik csoport esetében az egyéb kezelések és otthoni torna mellett thoracalis gerincmobilizációt is végeztek kiegészitésként. Mindkét csoport esetén szignifikáns javulást tapasztaltak, mind a légzési paraméterek, mellkaskitérés, mind a derékfájdalom tekintetében, azonban ez a javulás a gerincmobilizációban részesülő egyéneknél lényegesen nagyobb volt (37).

Janssens és munkatársai arra voltak kiváncsiak, hogy a belégzőizmok erősítése hogyan hat a proprioceptiv diszfunkcióra és a fájdalom mértékére LBP esetén. Alanyaikat 8 héten át tréningezték magas és alacsony intenzitással, belégzōizom erōsitō eszköz segítségével. A poszturális kontroll hatékonyságát egy erổplatón vizsgálták, amely a testtőmegközéppont kitéréseit detektálta. Az egyensúly fenntartásában komolyan szerepet vállaló izomcsoportokat (triceps surae, erector spinae lumbális tagjai) vibrációnak tették ki, ezzel vizsgálva, hogy mely izmok aktivációját preferálja jobban a derékfájdalommal küzdő beteg. Alapvetően a derékfájdalommal küzdō alanyok inkább a bokastratégiát használták az egyensúly fenntartásához, azonban a kutatók azt tapasztalták, hogy a belégzốizom tréning után ez a mintázat megváltozott, instabil felszínen elvégezve a feladatot. A 8 hetes intenzív tréning után a pácienseknek nem csak a törzsstabilizációjuk javult és erōsödtek a belégző̉izmaik, hanem hatására a derékfájdalom mértéke is szignifikánsan csökkent (38). 


\section{Megbeszélés}

Az eddigi kutatások mind alátámasztják a diaphragma alapvetố szerepét a lumbális gerinc stabilitásában. Derékfájdalom hatására, illetve annak fennállásakor a diaphragma müködésében változások lépnek fel, melyek a gerinc szegmentális instabilitását, a légzésben bekövetkezō változásokat és a poszturális kontroll romlását is elōidézhetik $(28,23,26)$. A légzési minta és ezzel a diaphragma mūködésének helyreállitására tehát szükségszerü figyelmet forditani a derékfájdalom fizioterápiás kezelése során $(33,34,35)$. Erre két kutatásban láthattunk példát, melyek során egyrészt a háti gerinc mobilizálásával, másrészt a diaphragma erősítésével jelentősen csökkent a LBP mértéke a vizsgálati alanyoknál.

A témában végzett kutatások alapján felmerül a kérdés, hogy vajon a rekeszizmot erösitö, funkcióját helyreállító kezelés, befolyásolná-e hosszú távon is a derékfájdalommal küzdố egyének fájdaimának mértékét és életminóségét? A diaphragma tréningezésével képesek vagyunk-e hatni a többi törzsstabilizátor izom mūködésére? A derékfájdalom kialakulásának és a krónikussá válás mechanizmusának részletes megismerése alapjául szolgálna egy fizioterápiás protokoll létrehozásának, mellyel a lumbágó komplexen és hatékonyan kezelhetổvé válna és alkalmazása mérsékelné a derékfájdalommal járó egészségügyi kiadásokat. Ahhoz, hogy a felmerülō kérdéseket megválaszolhassuk, szükség van további kutatásokra. 


\section{Irodalomjegyzék}

1. Koes BW, van Tulder MW, Thomas S. Diagnosis and treatment of low back pain. BMS. 2006 Jun 17;332(7555):1430-4.

2. Miura T, Sakuraba K. Properties of Force Output and Spectral EMG in Young Patients with Nonspecific Low Back Pain during Isometric Trunk Extension. J Phys Ther Sci. 2014 Mar;26(3):323-9.

3. Parfrey K, Gibbons SG, Drinkwater EJ, Behm DG. Effect of head and limb orientation on trunk muscle activation during abdominal hollowing in chronic low back pain. BMC Musculoskelet Disord. 2014 Dec 22;15(1):52.

4. Panjabi MM. Clinical spinal instability and low back pain. J Electromyogr Kinesiol. 2003 Aug;13(4):371-9.

5. Chang W-D, Lin H-Y, Lai P-T. Core strength training for patients with chronic low back pain. J Phys Ther Sci. 2015 Mar;27(3):619-22.

6. Willard FH, Vleeming A, Schuenke MD, Danneels $L$, Schleip R. The thoracolumbar fascia: anatomy, function and clinical considerations. J Anat. 2012 Dec;221(6):507-36.

7. Cholewicki J, VanVliet JJ. Relative contribution of trunk muscles to the stability of the lumbar spine during isometric exertions. Clin Biomech (Bristol, Avon). 2002 Feb;17(2):99-105.

8. Hodges PW, Richardson CA. Inefficient muscular stabilization of the lumbar spine associated with low back pain. A motor control evaluation of transversus abdominis. Spine (Phila Pa 1976). 1996 Nov 15;21(22):2640-50.

9. Kavcic N, Grenier S, McGill SM. Determining the stabilizing role of individual torso muscles during rehabilitation exercises. Spine (Phila Pa 1976). 2004 Jun 1;29(11):125465.

10. Cholewicki J, MCGill SM. Mechanical stability of the in vivo lumbar spine: implications for injury and chronic low back pain. Clin Biomech (Bristol, Avon). 1996 Jan;11(1):1-15.

11. Santos FG, Carmo CM, Fracini AC, Pereira RRP, Takara KS, Tanaka C. Chronic Low Back Pain in Women: Muscle Activation during Task Performance. J Phys Ther Sci. 2013 Dec;25(12):1569-73.

12. Hirata RP, Salomoni SE, Christensen SW, Graven-Nielsen T. Reorganised motor control strategies of trunk muscles due to acute low back pain. Hum Mov Sci. 2015 Jun;41:28294.

13. Lee $\mathrm{N}$, Kang H, Shin $\mathrm{G}$. Use of antagonist muscle EMG in the assessment of neuromuscular health of the low back. J Physiol Anthropol. 2015 Apr 24;34:18.

14. Radebold A, Cholewicki J, Polzhofer GK, Greene HS. Impaired postural control of the lumbar spine is associated with delayed muscle response times in patients with chronic idiopathic low back pain. Spine (Phila Pa 1976). 2001 Apr 1;26(7):724-30.

15. Abboud J, Nougarou F, Pagé I, Cantin V, Massicotte D, Descarreaux M. Trunk motor variability in patients with non-specific chronic low back pain. Eur J Appl Physiol. 2014 Dec 31;114(12):2645-54.

16. Farfan HF (Henry F. Mechanical disorders of the low back. Lea \& Febiger; 1973. 247 p. 
17. MCGill SM, Norman RW. Reassessment of the role of intra-abdominal pressure in spinal compression. Ergonomics. 1987 Nov;30(11):1565-88.

18. Hodges PW, Butler JE, McKenzie DK, Gandevia SC. Contraction of the human diaphragm during rapid postural adjustments. J Physiol. 1997 Dec 1;(Pt 2):539-48.

19. Hodges PW, Heijnen I, Gandevia SC. Postural activity of the diaphragm is reduced in humans when respiratory demand increases. J Physiol. 2001 Dec 15;537(3):999-1008.

20. Grillner S, Nilsson J, Thorstensson A. Intra-abdominal pressure changes during natural movements in man. Acta Physiol Scand. 1978 Jul; 103(3):275-83.

21. Hodges PW, Gandevia SC. Activation of the human diaphragm during a repetitive postural task. J Physiol. 2000 Jan 1;522 Pt 1(Pt 1):165-75.

22. Kolar P, Sulc J, Kyncl M, Sanda J, Neuwirth J, Bokarius A V., et al. Stabilizing function of the diaphragm: dynamic MRI and synchronized spirometric assessment. J Appl Physiol. 2010;109(4).

23. Ki C, Heo M, Kim H-Y, Kim E-J. The effects of forced breathing exercise on the lumbar stabilization in chronic low back pain patients. J Phys Ther Sci. 2016 Dec;28(12):33803.

24. Goosheh B, Ravanbakhsh M, Salavati M, Ebrahimi Takamjani I, Akhbari B, Kahlaee AH. Attention-demand effects on respiration in chronic low back pain patients. Journal of Bodywork and Movement Therapies. 2016; Dec; DOt: 10.1016/j.jbmt.2016.11.016

25. Kolár P, Sulc J, Kynčl M, Sanda J, Cakrt O, Andel R, et al. Postural Function of the Diaphragm in Persons With and Without Chronic Low Back Pain. J Orthop Sport Phys Ther. 2012 Apr;42(4):352-62.

26. Hagins M, Lamberg EM. Individuals with Low Back Pain Breathe Differently Than Healthy Individuals During a Lifting Task. J Orthop Sport Phys Ther. 2011 Mar;41(3):141-8.

27. Grimstone SK, Hodges PW. Impaired postural compensation for respiration in people with recurrent low back pain. Exp Brain Res. 2003 Jul 1;151(2):218-24.

28. Janssens L, Brumagne S, McConnell AK, Hermans G, Troosters T, Gayan-Ramirez G. Greater diaphragm fatigability in individuals with recurrent low back pain. Respir Physiol Neurobiol. 2013;188(2):119-23.

29. Janssens L, Brumagne S, Polspoel K, Troosters T, McConnell A. The Effect of Inspiratory Muscles Fatigue on Postural Control in People With and Without Recurrent Low Back Pain. Spine (Phila Pa 1976). 2010 May 1;35(10):1088-94.

30. Beeckmans N, Vermeersch A, Lysens R, Van Wambeke P, Goossens N, Thys T, et al. The presence of respiratory disorders in individuals with low back pain: A systematic review. Man Ther. 2016 Dec;26:77-86.

31. Smith MD, Russell A, Hodges PW. Disorders of breathing and continence have a stronger association with back pain than obesity and physical activity. Aust J Physiother. 2006;52(1):11-6.

32. O'Sullivan PB, Beales DJ. Changes in pelvic floor and diaphragm kinematics and respiratory patterns in subjects with sacroiliac joint pain following a motor learning intervention: A case series. Man Ther. 2007 Aug:12(3):209-18.

33. Vostatek P, Novák D, Rychnovský T, Rychnovská S. Diaphragm postural function analysis using magnetic resonance imaging. PLoS One. 2013;8(3):e56724. 
34. Roussel N, Nijs J, Truijen S, Vervecken L, Mottram S, Stassijns G. Altered breathing patterns during lumbopelvic motor control tests in chronic low back pain: a case-control study. Eur Spine J. 2009 Jul 10;18(7):1066-73.

35. Chaitow L. Breathing pattern disorders, motor control, and low back pain. J Osteopath Med. 2004;7(1):33-40.

36. Perri MA, Halford E, Taylor W, Jenner F. Pain and faulty breathing: a pilot study. J Bodyw Mov Ther. 2004 Oct 1;8(4):297-306.

37. Babina R, Mohanty PP, Pattnaik M. Effect of thoracic mobilization on respiratory parameters in chronic non-specific low back pain: A randomized controlled trial. J Back Musculoskelet Rehabil. 2016 Aug 10;29(3):587-95.

38. Janssens L, McConnell AK, Pijnenburg M, Claeys K, Goossens N, Lysens R, et al. Inspiratory muscle training affects proprioceptive use and low back pain. Med Sci Sports Exerc. 2015;47(1):12-9. 


\title{
Effects of exercise therapy on postural stability, multifidus thickness, and pain intensity in patients with chronic low-back pain
}

\author{
R FINTA ${ }^{1 *}, 1$ POLYÁK ${ }^{2}$, T BENDER $^{3}$ and E NAGY ${ }^{2}$
}

${ }^{1}$ Department of Physiotherapy, Faculty of Health Sciences, University of Szeged, Szeged, Hungary

${ }^{2}$ Affick Diagnostic Lul., Sreged, Hungary

${ }^{3}$ Buck Hospital of the Hospitaller Order of Saint John of God, Budipest, Hungary

(Received: February 4, 2019; revised manuscrint received: May 29, 2019; accepled: June 12, 2019)

Puppuse: We examined the effects of exercise therapy on postural statility, multifidus thickness, and pain intensity in patients with low back pain. Maserials and methods. Subjects were divided into a chronic low-back pain (CLBP; $n=10$ ) group and a healthy control (C; $n=10$ ) group. Groun, CLBP bok part in an 8-week training programme, whereas group $\mathrm{C}$ did not. The thickness of the multifidus in both groups was assessed using ultrasonography before and after 8 weeks, in prone and kneeling positions, in relaxed and contracted states. A standing heel-raising test was used to asses postural stability. Resulf.s. Afler the intervention in group CLBP, the thicknes of the contracted multifidus increased in the prone position, whereas the thiclness of both the contracted and relaxed multifidus decressed in the kneeling position. In gnup C afler 8 weeks, multifidus thiclness decressed in both positions, while both relaxed and contracted. Group $\mathrm{C}$ performed the standing heel-raising test significantly better than group CLBP before the 8-week period. Afler the training, group CLBP improved significanty, but no changes were found in group C. Discassion and conchusions. Changes in thickness of the multifidus correbte with improved postural statility and decreased pain intensity. Decrasing thickness in healthy individuals may be an early sign of developing CLBP.

Keywords: postural stability, ultraxonography, low-back pain, atrophy

\section{INTRODUCTION}

Chronic low-back pain (CLBP) affocts people in their active ages, and as more and more young poople are affectod nowadays, it decreases the productivity of working-age generations [1]. CLBP cases can be divided into two groups: those with specific and those with non-specific low-back pain. Specific causes are medical conditions, whereas non-specific CLBP is lumbar pain without a known medical reason or humbar pain that is not attributed to a specific pathology [2].

Facts about lumbar instability

Non-specific CLBP may be caused by segmental instability of the lumbar spine [3]. There are many hypotheses, which try to explain what segmental spinal instability is. According to the "neutral zone concept" by Panjabi, a neutral zone and an elastic zone can be differentiated in the total range of movement (ROM). The neutral zone is the initial part of the segmental movement where intemal resistance is minimal, whereas the elastic zone follows after the neutral zone, and the movements occur against intemal resistance in the end range of the ROM. When segmental instability emerges, the extent of the neutral zone is increased. Lumbar segmental instability occurs when the capacity of the stabilizer system has decreased, and a nomal neutral zone cannot be maintained [4]
Stabiliter subsystems of the lumbar spine

There are three subsystems responsible for maintaining lumbar stability, namely: the passive, neural, and active subsystems. The passive subsystem is granted, and it is difficult to affect its functioning by non-invasive techniques. Ligaments, tendons, vertebrae, and discs belong to this subsystem. The passive subsystem has the most important role in stabilizing the elastic zone of the ROM. The newal control subsystem has a unique role in the timing of muscle activation conesponding to the given movement [5]. People with low-back pain have reduced postural stability in standing and in sitting positions, and they react worse to disturbing circumstances [6]. Healthy people rely on a multisegmental strategy of postural control to maintain a standing position. They use proprioceptive information from all of their body parts, including the low-back area. When CLBP develops, the neural system reorganizes the sources of the proprioceptive information because of the lack of information from the low-back area. Therefore, people with CLBP mostly use information from the joints of the ankle and apply the ankle strategy more to maintain their postural stability [7]. As a consequence, lumbar pain

* Comegonding author: Regina Finta Depatmant of Physiotherapy, Faculty of Hedth Sciences, University of Sregal, Temesviri lart. 31,

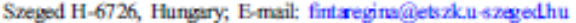

This is an open-access article distributed under the terms of the Creative Commons Attribution 4.0 Internationsl License, which permits unrestricted use, distribution, and reproduction in any medium, provided the original author and source are credited, a link to the CC License is provided, and changes - if any - are indicaled. (SID 1) 
influences the body's inclimation in the standing position. People with low back pain kan more forward than the healthy people [7]. Brumagne et al. [8] oonducted a study on young people with a short history of $10 \mathrm{w}$-back pain and ocmpared them to healthy people. They found significant diffenences between the low-back pain group and the healthy groun. When visual input was not available, mem. bers of the low-back prin group leaned and posiboned the centre of pressure (COP) forward significantly.

The third subsystem is the active subsystem. The active and neural subsystems are primarily responsible for spinal stability in the neutral zone [5]. The muscles' role is promi nent in defending the spine from detariorative impacts Mul tisegnental, more supenficial muscles are responsible for producing the movements of the trunk. Unisegnental deep musdes function primarily as force transducars, fasten the vertebre to each other, and provide feedhack on spinal position and movemants for the neural comtrol subystem. The lumbar multifidus muscle is one of the most important musdes in segnental control and has a sigrificant role in stabilizing the lumbar spine [5]. Changes of the muscle's morphology, alterstions of its fundion, and the atrophy of this musde may cause CLBP. The oonverse can also ocur [9].

\section{CLBP and change in muscle function}

Chronic pain causes changes in musculoskdetal functions [10]. Protective adaptation may be the reason for these changes in motor performance, $\mathbf{s}$ the pain influences the segnental intemeurons. As a result, an incrase in muscle tane emenges in peonle with CLBP. The boost in muscle tone is due to the excalation of stretch reflex activity caused by increased $\gamma$-motoneuron discharge [11]. A pain-spasm-pain model may characterise the neuromuscular alaptation to lumbar pain [10]. The pabents' activities are diminished due io pain and stifties, which result in muscle spasn and strain and evernually this situation aggavates pain in avicious cycle [12]. Raluced proprioceptive input may cause neuromuscular deficiendes. Such oonstant malfunctioning of neuromuscular control and flawed regulation of dynamic movements may lead io inappropriate musaular activity (i.e., overutilization or underutilization), which may cause further deteriorstions of the muscular system. These symptoms worsen though sensitization of the peripheral and central nervous systems (lowering pain threshold) which promotes dysfunctional movement pathems [12]. Training of the affected musdes can reduce the pain, improve the strbilizer musde function, and provide normal proprioceptive feedhack [13]. CLBP affects muscle function in the lumbar area and cause dysfunction in the lumbs multifidus muscle [14].

The aim of this study was to investigate the effect of an 8-week taining progname on the thiciness of the lumbar multifidus muscle in patients with CLBP. We monitored the change in thickness in the various stages of pain.

\section{MATERIALS AND METHODS}

\section{Participants}

Young adult participants were recruited from our university, and they were divided into two groups: group C (control) for asymptomatic individuals and group CLBP for individuals with a history of CL.BP (at least 3 months duration of pain [15]). Altogether, 20 subjects were recruited: 10 for group CL.BP and 10 for group C. The avenge age was 20.70 years $(S D=1.49)$ in group CLBP $(n=10)$ and 22.30 years $(S D=1.06)$ in group C $(n=10)$. The inclusion criteris for group CLBP were CLBP, not undengoing any other treatment during the investigation, and being able to get to the location of the training. The inclusion criterion for group $\mathrm{C}$ was no history of CLBP. Exclusion criteria for both groups were balance problems with a neurological cause, a malignant tumour, a serious organ disease, a previous surgical intervention that affected the trunk, or an inability to cooperate. Because of the tectious measuring process, onty physiotherapy students were included in the study, since they have a more devekpned peroeption of movement and body awrenes based on the characteristios of physiotherapy education. All prerticipants took part voluntarily in the study and gave their written informed oonsent. The study was in comnliance with the princinles of the Declarstion of Helsinki.

\section{Training}

The members of group CLBP participated in an 8-week complex training programme. There were two training sessions per week ( 1 hr each). At the beginning of each session, there was a warm-up period and at the end there was a cooklown period, each of $10 \mathrm{~min}$ durabion. The main part of the training involved mostly strengthening, strekhing. and motrilizing exercises for the musdes of the trutik and the hip. Static and dynamic exercises were performed with the help of tools (e.g, elastic bounds, dumbbelk, and heavy balls) and without tools. The programme was completed with balance exercises. Training tools were used to improve members' balance throughout static and dymic exercisex. Three physiotherapists ensured correct implementation of the exexises. Contrary to group CLBP, memhers of groun C did not take part in any training during the 8 -week period.

\section{Mearuements}

We massured the thidkness of the lumbar multifidus muscle's belly and the intensity of the pain. The pain was assessed in $\mathrm{cm}$, using a Visual Anakg Scale [16]. The thickness was measured by B-mode ultrasonography on both sides of the trunk, using a Zorare ZOne Ulinsound System (ZONARF Mectical Systems, Mountain View, CA, USA, 2013) in two different positions (prone and kneeling positions) and in two different states (nelaxed and controcted states). The thiclanes was measured by placing the electroniccalipers just inside the hypenechoic comective tissue layers.

During measurements in the prone position (lying on the chest with the face down), the curved transducer (with a frequency range between 6 and $2 \mathrm{MHz}$ ) was usal longitudinally akong the spine, with the midpoint over the LA spinous process. It was moved laterally and angled slightly medially until the LA/S zygapophyseal joint coukd be identifed, and the muscle was assessed in a relaxed (calm lying) position and in a contracted state [17]. The students were asked to contract the muscles of the lumbar area without extra movement of the trunk. To reach a more efficient 
muscle contraction, tactile stimulation was implemented. above the hypothesized area of the muscle [18].

To examine the postural activity of the muscle, the thickness of its belly was measured in a kneeling position as well. In the lneeling position, the postural function of lumber multifidus is enhanced due to the vertical position. The students were instructed to keep an erect posture. When they held a quiet kneeling position, it was defined as a relatively relaxed state, and when we asked them for muscle contraction, it was defined as a relatively oontracted state. To enhance the contration caused by the postunl activity of the lumbar multifidus musde, tactile stimulation was applied in the kneeling position as well (Figure 1).

To ensure the same setting for ultrasonography, the skin surface was constantly marked, and the measurement was carried out by the same person with experience in ultaso. nogaphy. Test-retest reliahility was tested by calculation of intraclass correlation and the relia bility coefficient. Both the hight interclass correlations $(0.991-1.000)$ and the small repeatability coefficients $(0.008-0.095)$ showed good reliability [19].

For testing the improvement of the lumbar stabilizer system, a modified standing heel-raising test was applied. The test is commonly used is assess the function of plantar flewors, essential muscles for bocmotion, and postunal tasks [20]. In this study, it was performed on an unstable surface (Dyrair) to challenge the postural function of the stabilizer muscles. The participants had to stand in the middle of the dis and raise their heels continuously within $30 \mathrm{~s}$ and the number of the raises was courted. The testing procedure was performed before and after the 8-week period.

\section{Dusa anabysis}

The data analysis and the calculations were exeauted with Microsoft Office Exoel and STATISTICA 13 software (Stat. Soft, Inc, Tulsa, OK). The Shaniro-Wilk test was used as a nommelity test. To compare the changes that occurral within one group affer 8 weels, the Wilooson Matched Pais Test was used. To compare the two grouns, the Mamn-Whitney $U$ test was used. The level of sigificance was set at $p<.05$.

\section{RESULTS}

Pain

After the training, the severity of the pain decreased from 5.76 to $2.3(\mathrm{~cm})$ in group CLBP $(p=.007)$.

The thickness of humbur mulityidus muscle

Comparing the before and after data for group CLBP, we found that the thickness of lumbar multifidus muscle increased in the prone position in the oontacled state, with a significant difference in the left muscle $(p=.017)$. With group CLBP in the kneeling position, some decrease in the thicknesses was found in every condition, and it was significant in the left muscle in the relatively relaxed state $(p=.009$, Figure 2).

In group $\mathrm{C}$, the thickness of lumbar multifidus muscle decreased in all conditions after 8 weeks. Interestingly, reduction was mone marked in the relaxed state than in the contracted state. Significant changes were found in the relatively relaxed states of the muscle in the kneeling position. The extent of the significant decreases in the leff muscle $(p=.020)$ and the right $(p=.028)$ were approximately the same (Figure 3).

\section{Modified standing heel-raise test}

Before the 8-week training programme, members of goum CL.BP peformed, on average, $25.80(S D=2.94)$ heel-raises within $30 \mathrm{~s}$, and members of group C performed 30.70 $(S D=4.32)$. This was a sigrificant difference $(p=.021)$. After 8 weeks, the performance of group CLBP increased significantly $(p=.008)$ as they performed 33.20 $(S D=4.64)$ heel-raises. The members of goup $\mathrm{C}$ did not (a)

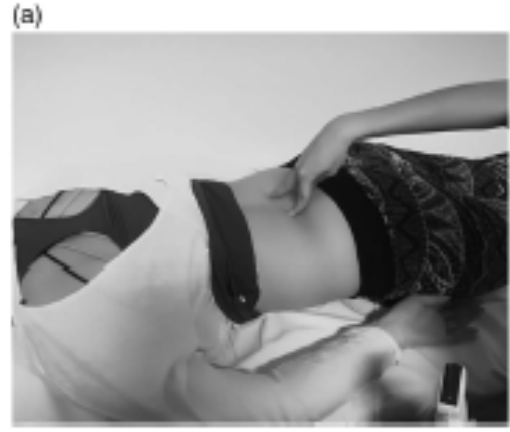

(b)

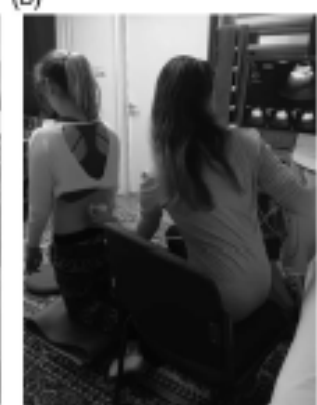

Figue 1. (a) The ultnsonography procedure. The thickness of lumbar maltifidas muscle was mensured fist in a prone position. The quiet lying was the relax ad state and the contneted state was performed with the help of tactile stimalation on the low bxk ara. (b) Lambar multifidus was measured in a lneling position. During this vertical position, the postural function of the muscle was anhanced in the relatively relaved state as well. The relatively contracted state of the muscle wns performed the same way as in the case of the prone position 


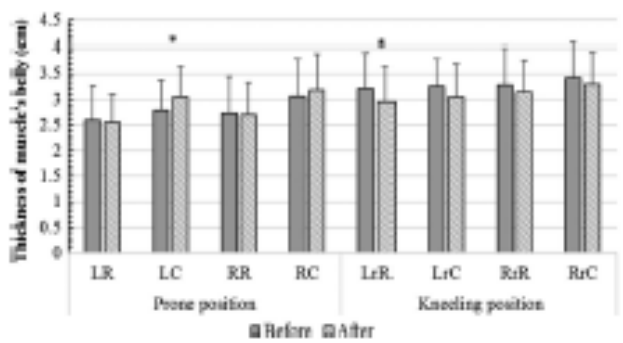

Figare 2. The thickness of lumbar mal tifichs muscle's belly in case of group CL.BP. In the prone position, increased thiclmes ser of the murcle' belly were foumd in the contnded stres and the thidnes of the muxkle's belly decreared in every strte in the lneeling position. LR: lef-sided, relmed; LC: left-sided, contrated; RR: rightsidat, reluxat; RC. night-sided, contrated; r: rlatively. ${ }^{*} p<.05$

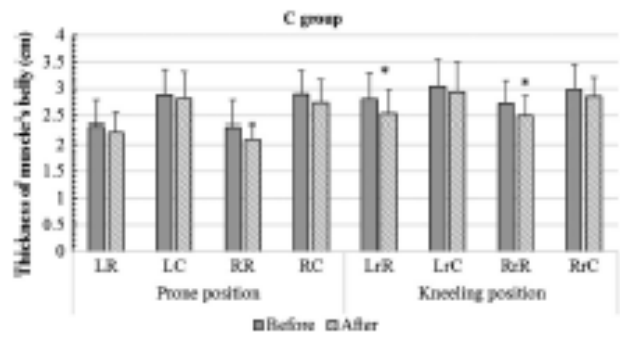

Pigure 3. Thickness of humbar multifidus muske's belly in groun C. Decreases were frund in the thickness of the muxcle under all conditions. The changes were significant in case of the relatively meluxad stzes in the lmeeling position. L.R: lefteidad, reluxat; LC lef-sided, contrxted; RR: rightsided, reluxed; $\mathrm{RC}$ : right sided, contracted; r: relatively. ${ }^{*} p<.05$

improve their performance significantly $(p=918)$. The significant difference found between the two grouns $(p=021)$ before 8 weeks varished by the time of the postlests $(p=.496$; Figure 4$)$.

\section{DISCUSSION}

Our main findings were that during 8 weeks of traiming for group CL.BP, the intensity of pain decreased, postural statility improved, and changes occurred in the thickness of the lumber multifidus.

Changes in the thickosess of hambor mudafidus mascle of grap CLBP

When it was in contraction in the mone position, the thickness of the lumbar multifidus muscle increased after the training. When ultraxonography was performed, both in relaxed and contracted states in the prone position, the muscle's belly was in the neutral state, as in this position, the muscle was not influenced by the enhanced postural

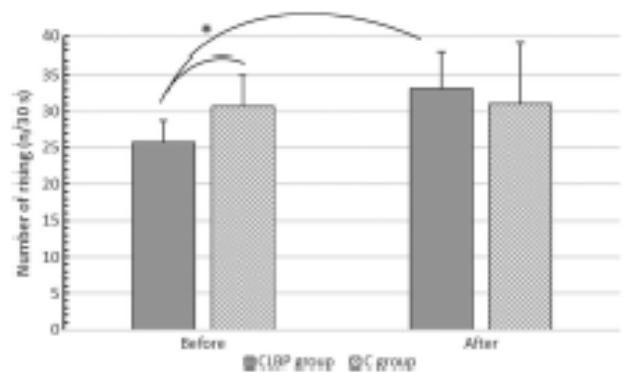

Ppove 4. Number of hol-ruises before and aftar 8 woxks. Significant difference was found betwoen the groups during the pretesting porcedur. The output of group CLBP imporved significuntly as a renult of the training. There was no change in group $\mathrm{C}$ after 8 weeks. $* p<.05$

function seen in vertical positions [21]. The thicker belly in the contracted state in the prone position indicated the improved contradile ability of the muscle [22]. Considering the facts that the multifidus muscle is smalker in patients with CLBP [23], and that these patients have a reduced ability io voluntarily contract the muscle than healthy people [18], our results indicate that exenise therapy results in a positive change in the condition of the lumbar multifidus muscle in CLBP patients

Pain can be reinforced by increased co-contraction, which may result in increased stiffness in the lumbar aras and altared biomecharical losding [24]. Pain alone can cause an increased muscle thidkness [25]. The pain-spasm-pain cycle is a motor control pattem that has the effect of perpetusting the painful disorder, but it also protects the system by maintaining stability on a higher level $[26,27]$.

Our results showed significant reduction in pain level in group CLBP. For these patients there was a decreased muscle thickness in the relaxed state in the prone position. However, when voluntary oontraction occurred in the prone position, the thickness of the lumbar multifidus muscle belly increased. In the kneeling position, the thickness decreased, even though this posture chalkenged the multifidus muscle more than the pasive prone position [21]. The pain relief may have rectuced the stain of the muscle, which resulted in the decrease in its thickness

We surpose that the changes obsarved in this study show that the increased co-oontraction (in group CLBP) developed by our training programme results in a more norma functioning. With the lumbar pain being relieved by the intervention, the pain-spasm-pain cycle might have been broken [28]. B raking thepain-spasm-pain cycle may be an explanation for the significant decrease in the thickness of lumbar multifidus muscle in the kneeling position.

To date, conflicting evidence can be found regarding the stabilizer musdes' role and the advantages of strengthening them in CLBP patients, but considering that CLBP is complex condition [29], it is clear that only one muscle should not be the focus of attention during CLBP management Therefore, our intervention contains holistic strength. ening exercises that activate not only the lumbar multifidus muscle, but also all members of the active stabilizer system 
of the trunk. The members of the stahilizer systems have an influence on each other. Thus if the function of even one muscle of the active stabilizer system deteriorates, it even tuates an increased demand on the other subsystems to maintain stability [S].

Besides the treaking of the pain-spasm-pain cycle, a further possible explanation for the decrease in the multi. fidus' thickness in the lneeling position is that in the laneeling position all statilizer muscles need to be more active to maintain the vertical position of the body than in the passive prone position [21]. Based on this observation, we asume that the activation of the lumbar multifidus was reduced by the neural system as a result of improved function of the whole statilizer system after the exercise therapy. The increased tension of lumbar multifidus musck was no longer necessary.

In addition, the observed decrease in the muscle: thickness in the kneeling position in group CLBP can be attributed to a change in posture affer our intervention. Former studies proved that individuals with low-back pain prefer the ankle strategy to maintain stbility $[12,30]$, and consequently, they lean and position their COP forward [ $\mathrm{g}]$. As a resalt of our intervention, a decreased thickness of the lumbar multifidus muscle's belly was assessed in groun CLBP in the vertical, kneeling position. The thicker lumber multifidus muscle measured before the intervention may be a sign of the forward-laning position [31] preferred by people with low back pain [8]. With the reduced pain intensity due to the traiming programine and the improved sathilizer muscles' function, the postural ahinnment of the trunk might have changed into a more natural condition [30]. The change of posture from a forwand-learing position to a nomal posture influences the functioning of the stabi bizer muscles of the trunk [31]. The activity of the muscles in the low-back area is lower in a normal posture than in the forward-learing position [31] developed by CLBP. After the 8-week training programime, decreases in the thickness of multificus were observed by ultrasound examination in goup CLBP. Therefore, the observed changes in lumbar multifidus muscle might be an indicator of the recovery of normal posture.

We think that the increase in the thickness of lumber multifidus muscle during contraction in the prone position and the decrease during relaxation in the prone position, as well as in both oontraction states of the vertical, kneeling position were the result of a positive change in group CLBP, which occurred primarily due to the training programme.

Changes in the thickness of the humbar mulityials muscle in grap $C$

Surprisingly, a decrease occurred in the thickness of lumber multifidus muscle under all conditions in group C. During the 8-week period, members of group $\mathrm{C}$ comtinued their taily routine. Because of the decrease, members of the group were asked if thene had been any changes in their daily activities and if they had experienced any pain or stiffness linked to the low-back area during the study. Al members of group $\mathrm{C}$ claimed that during the autumn semester, when this study was conducted, they had spent much more time in the sitting position than during the surnmer vacation before our research began. The students reduced the amount of their physical activity in order to be able to fulfill the requirements of their school. Interestingly, $50 \%$ of group $\mathrm{C}$ developed low-back pain in the last few weels of the research. Beasuse of the reduced physical activity and the poor posture, generally applied during sitting, atrophy of the lumbar multifidus is presumable. Studies have shown that an altered function and atrophy of the lumbar multifidus muscle can be a cause of CLBP $[5,9]$. Our findings suggest that a decrease in the thiclaness of the lumbar multifidus muscle may indicate a change in its function. It therefore may be an early sign of developing low back pain.

\section{Outcomes of the madified heel raise test}

The results of the modified heel-raise test, which used the unstable Dynair to challenge the postural function of the stabilizer muscles, support our hypothesis that the vicious cycle was broken. People with CLBP have a reduced postural stability, and they react worse is disturbing circumstances [6]. The members of group CLBP showed significant improvement after the intervention, even though they had no chance to practice the test, and there were no exercises for strengthening the triceps surse muscle during the training penod. Strengthering of the trumk and hip muscles was emphasized, tius, presumably, the stbility of the proximal area (trunk) was imrroved, thereby facilitating the distal function of heel-raising [32]. Because of the intervention, the severity of pain was reduced, and the stabilizer muscles became stronger, which together resul ted in a significant increase in the postural stability of the CLBP patients In contrast with group CL.BP, there was no development in group $\mathrm{C}$.

\section{Limisutions}

This sudy had severd limitations. One was the low number of partidpants, but the recruitment of prospedive participant: for an extended study is already in progres. Another was that the mechaniam of the changes in the thiclanss of hunbar multifidus muscle due to the training mograme was not clarifial. The posture and the position of the COP should be measured before and after the intervention, but the applied kneeling position was not suitahle for detecting these changes using NeuroCom Basic Balance Mastar device (Paragon Care Group Pty Ltd, Clayton, Australia). The standing position would be more mmogricte to asess the forwarl-kaming position seen in CLBP pretients. It would be beneficial if we could compare the thickness of the lumbar multifidus musde in CLBP patients to that of the healthy subjects, but the nommalizing pocedure is not clarified yet [33].

\section{CONCLUSIONS}

The significant results of this study were that, as a result of the applied exercise therapy for group CL.BP, changes occurred in the thickness of their lumbar multificus muscle, their postural stability improved, and their low-back pain 
was relieved Degrite the low sample size, significant changes and clas tendencies were found. However, further research is necessary to investigate the exact reason for these changes. The decreased thickness of multifidus muscle's belly and the simultaneously ampearing low back pain in the healthy individuals draws attention to the importance of lifestyle in the occurrence of low-back pain. Moreover, the decrease in muscle's thicknes raises the possibility that this change may be an early sign of developing low back pain. However, the precise role of the multifidus muscle in CLBP is still unclear [34]. Our investigation mainly focused on lumbar multifidus muscle, but in general CL.BP develons as a result of many factors, including social and psychological factos [24]. This study helps to reveal only a few aspects of this complex phenomenon. In conclusion, we can say that the exercise therapy we developed is a viable way to improve muscle function in petients with CLBP. Additionally, the observed changes in muscle function may help in the effort to better understand the altered muscular activa: tion pattem in patients with low back pain.

Aubhors' contribution: RF contributed in the conception and design of the study and the acquisition of data. IP designed the ultasonography. TB and EN drafted and revised the article and share senior authorship.

Ethical aproval. The study is in compliance with the principles of the Declaration of Helsinki.

Confict of Interest Funding. The authors declare no conflict of interest and no financial support was received for this study.

\section{ABBREVIATIONS}

\begin{tabular}{|c|c|}
\hline CLBP & : chronic low-beck pain \\
\hline ROM & : range of movement \\
\hline COP & : centre of pressure \\
\hline$S D$ & : standard deviation \\
\hline C & : control \\
\hline
\end{tabular}

\section{REFERENCES}

1. Allegri M, Montella S, Salici F, Valante A, Marchesini M, Compagnone C, Bacirello M, Manfardini ME, Fanelli G. Mechrnisms of low back pain: a gride for dizgnosis and thersy. F1000Rer. 2016;11(5):1530.

2. Deyo RA, Wainstein $\mathbb{N}$. Low bak pain. N Engl J Mad. $2001 ; 344(5): 363-70$.

3. Prnjabi MM. Clinical spinal instability and low back pain. J Eledromyogr Kineriol. 2003; 13(4) 37 1-9.

4. Panjabi MM. The stabilizing system of the spine. Part II Neatml zone and instability hypotheris. I Spinal Disord. $1992 ; 5(4) ; 390-6$

5. Fintz JM, Ehard RE, Hagen BF. Segmental instubility of the humberspine. Phys Tha. 1998; 78(8) $8899-96$.
6. Clacys K, Brumagne S, Drnkaents W, Kiars H, Jnssans L. Decress d variability in postural oontol strategies in young poople with nonspocific low back puin is associted with ahered propriocegtive reweighting. Eur I Appl Physiol. 2011;111(1):115-23.

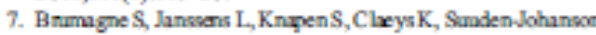
E. Ptrsons with naurent low badk puin exhibit a rigid postun contrd stategy. Eur Spine J. 2008;179):1177-84.

8. Brumagne S, Jussens L, Janssens $E$, Godtyn L. Alered postinl contol in anticipation of postural instability in pessons with nearnent low badk pain. Git Posture. 2008,28(4):657-62.

9. Swreney $N, O^{\prime}$ sullivan C, KellyG. Maltifidus marele size and parontage thickness chrnges among prients with uniltaral chronic low back pain (CI.BP) and healthy controls in prone and standing. Man Tha. 2014;19(5):433-9.

10. Manse S. Robart DG. Muscle Phin: Understanding the Machanims. Bertin, Hoidelberg: Springe-Verlag; 2014

11. Hinyana J, Yamagata M, Ogra S, Shimiza K, Ikada Y Takahahi K. Relationchip batween low baxk puin, maske spam and pressure puin thresholds in prients with humb dise harniation. Eur Spine I. 2006;15(1):41-?

12. MeCaskey MA, Schusta-Amft C, With B, Suica Z, de Bruin ED. Effects of propriocptive exeriser on pain and function in chronic neck- and low back pun rahabilitation: a systanntic literature review. BMC Masculoskelet Disord. 2014; 15:382.

13. Daman M, Shiravani F, Hementi L, Taghiradeh S. The effed of ombined exerive tharapy on knee proprioception, puin intensity and quality of life in putiants with hypemobility syndrome: a randomized elinical trial. J Bodyw Mov Ther. $2019,23(1): 202-5$

14. Freeman MD, Woodham MA, Woodham AW. The mole of the lumbar multifidas in chronic low bak pain: a review. PMeR. $2010,2(2): 142-6$.

15. Duthey B. Low badk pain. In: Priodity Mediaines for Europe and the World "A Public Health Approuch to Innovition". Upd te on 2004 Brkground Paper, 2013. p. 4-23.

16. Huskisson E. Monsurement of pin. Lanoet. 1974;304(7859): 1127-31.

17. Kiesel KB, Uhl TL, Lnderwood FB, Rodd DW, Nitz A. Messuramant of humbar maltifides mascle cantaxtion with rohabilits ive ultracund imsging. Man The 2007;12(2):161-6.

18. Wallwork TL, Stanton WR, Freke M, Hides JA. The effect of chromic low bak puin on sine and contraction of the humb a multifitus musele Man Ther. 2009;14(5):496-500.

19. Finta R, Nayy E, Benda T. The effect of dighingem thining on humber stabiliza muscles: a new concopt for improving segmantal stability in the ase of low badk pain. J Pain Res. 2018; $11: 3031-45$.

20. Svamtesson U, Herbart-Losier K, Wessman $C$, Alricsson $M$. The standing hed-rive tent: $\pi$ ferance values and test retert reliability for healthy individuals from 20 to 81 yours of age. Physiothenpy. 2015; 101(1): 1458.

21. O'sullivan $P B$, Grah mms lrw KM, Kandell M, Lapenakie SC Moller NE, Richards KV. The effoct of different standing and siting postures on tunk muscle xtivity in a puin-foe popa. lation. Sppine (Phila Pa 1976). 2002;27(11):1238-44.

22. Zhang S, Xu Y, Han X, Wu W, Tang Y, Wang C. Punctiona and morphological ehrnger in the deo humbar multifidus using eledromyograhy and ultnsound. Sei Rep. 2018:8(1) 6539 . 
23. Fortin M, Mrado LG. Multifidus and parapinal musele group arossectional aress of patiants with low back pain and contol patients: a systamitic review with a focus on blinding. Phys Thar. 2013;93(7):873-88.

24. O'sulliv m P. Common mixconceptions about badk pain in sport: Tiger Woods' case brings five find mantal quartion into shrp focus. Br J Sports Med. 2015;49(14);905-7.

25. Koppenhaver S, Harris D, Harris A, O'Connor E, Dummar M, Croy T, Walke M, Flynn T. The reliability of rahabilitative ultrasound imaging in the measurement of infaspinatus muscle function in the symptomatic and syymptomatic shoulders of prtients with unilateral shoulder impingement syndrome. Int J Sports Phys Ther. $2015 ; 10(2): 128-35$.

26. Hodges PW, Cholewieki J, Vm Dixen JH. Spinal $\infty$ ntrol; the rchabilitzion of bak puin: state of the art and science Physiother Can. 2015,67(4):394.

27. Lee HJ, Lim WH, Patt J-W, KwonBS, Ryu KH, Lee JH, Pari YG. The relation ship between aross sectional aron and strength of back museles in patients with chronic low bak pain. $A m n$ Rehabil Med. 2012;36(2): 173-81

28. Langevin HM, Sharman KJ. Pthophysiological model for ehronic low bak pain integnting oomective tissue and navous systan mechrnisma. Med Hypotheser. $2007,68(1)$ 74- 90.

29. Ledermm E. The myth of oore stability. J Bodyw Mov Ther. 2010;14(1):84-98.

30. Jnsens L, MoConnell AK, Pijnenturg M, Cheys $K$, Goosuans N, Lysans R, Troostars T, Brumagne S. Infpiratory muscle trining affects proprioceptive use and low badk pin. Med Sa Sports Exer. 2015;47(1):12-9.

31. Floyd WF, Silve PHS. The function of the erectors spin $x$ museles in certain movemants and postures in man. J Physiol. 1955;129(1):184-203.

32. Wilkon J, Dougherty CP, Fel and ML, Davis M. Core stability and its relationship to lower ex tremity function and injury. J Am Acad Orthop Sarg. 2005;13(5):316-25.

33. Lind P, Salicz E, Wolny T, Mystiwiee A. Body mas nomalisation for ultracund mesurements of adolescent Itteral abdominal mascle thidmess. J Utrasound Med 2017;36(4):775-82.

34. Wong AYL, Prant BC, Funzachi M, Stanton TR, Kawch GN. Do various baseline chandaristios of trossvasus abdominis and humbar multifidas protict clinical outcomes in nonsecific low back pain? A systanatic nview. PAN $2013 ; 154(12): 2599-602$. 
III.

\title{
The effect of diaphragm training on lumbar stabilizer muscles: a new concept for improving segmental stability in the case of low back pain
}

\author{
This article was putiahed in the following Dow Prest journat \\ |loural of Pain Researdi
}

Regina Finta'

Edit Nagy'

Tamás Bender ${ }^{2}$

Dopartment of Physlocherapy, Faculty of Health Sclencess, University of Stegod, Stoged, Hungary: 'Dapartment of Orthopedics, Faculty of Modicline. Doctoral School of Clinical Modicine. University of Szogod, Szeged, Hungary

Video abstract

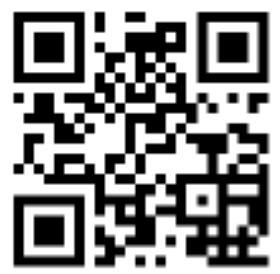

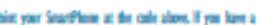

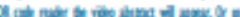

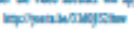

Corrospondence: Rogina Fint Derpaspondence Rogina Finta of Health Solences, Untworstity of Szeged. Temesvarl krt. 31, H-6726 Sreged, Hungary

Hungary

Enval fintaregina gletszk u-szeged hu
Purpose: The aim of this study was to assess the effects of diaphragm training on low back pain and thickness of stabilizer muscles of the lumbar spine.

Patients and methods: Fifty-two individuals were recruited with a history of chronic low back pain in our randomized controlled trial. The participants were divided randomly into two groups. One of the groups took part in a complex training program and completed with diaphragm training (DT group, $n=26$ ). The control (C) group took part only in the complex training $(\mathrm{n}=21)$. The thickness of transversus abdominis, diaphragm, and lumbar multifidus muscle was measured with ultrasonography in two positions: lying and sitting. All muscles were assessed in relaxed and in contracted state in the lying position and in a relatively relaxed (calm sitting) and relatively contracted state (during weightlifting) in the sitting position.

Results: After the training, severity of the pain was significantly reduced in both the groups. Regarding the thickness of the muscles, there were no changes in group $\mathrm{C}$. The thickness of transversus abdominis increased significantly in relaxed and in relatively relaxed state, but there were no changes in contracted and relatively contracted state in group DT. As for the diaphragm muscle, there were significant increase in the state of supine position and in relatively contracted state, but there was no notable change in relatively relaxed state. With regard to the thickness of lumbar multifidus, a significant increase was only found in the left-sided muscle in relaxed. relatively relaxed, and relatively contracted state and in case of the right-sided one in relatively contracted state in group DT.

Conclusion: Our results suggest that diaphragm training has an effect also on the thickness of other active stabilizers of the lumbar spine, such as transversus abdominis and lumbar multifidus muscles.

Keywords: chronic low back pain, ultrusound assessment, lumbar stabilization, postural function

\section{Introduction}

Chronic low back pain (CLBP) is a very common problem in developed countries and affects the entire population from children to the elderly. ${ }^{1}$ Chronic pain has a negative effect on the individuals' lives as well as on the whole society. This is the main cause of inactivity and job absenteeism. ${ }^{1}$ Low back pain is among the top ten high burden diseases and injuries, with the average number of disability-adjusted life years, higher than that of HIV, road injuries, tuberculosis, lung cancer, COPD, and preterm birth complications. ${ }^{1}$ Low back pain has been ranked as the greatest contributor to global disability. ${ }^{2}$ Based on the etiology, CLBP can be divided into two types: nonspecific and specific low back pain. If the pathological reason is known, it is called specific 
low back pain, but if the reason for the pain is not known, it is classified as nonspecific CLBP. ${ }^{1}$ The majority of low back pain cases are nonspecific CLBPs, which makes the treatment more complicated. ${ }^{3}$

One of the postulated reasons for nonspecific low back pain is the segmental instability of the lumbar spine. ${ }^{4}$ The concept of segmental instability has not yet been proven in vivo; experiments were performed in vitro on cadaveric

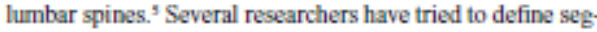
mental spinal instability, but there is no accurate definition for the subtle forms of instability which are present when nonspecific low back pain occurs. This subtle instability may not be detected by radiological techniques or physical examination. One of the possible explanations for this instability is the "neutral zone concept" proposed by Panjabi. ${ }^{6}$ Based on the theoretical findings, the total range of motion (ROM) of a spinal motion segment may be divided into two zones: a neutral and an elastic one. The neutral zone is the initial part of the total ROM and spinal motion is produced against minimal internal resistance in this zone. The elastic zone is the portion nearer to the end-range of movement that is produced against significant internal resistance. ${ }^{6}$ Increased segmental laxity occurs when the size of the neutral zone increases. ${ }^{5}$ The expansion of the neutral zone may occur as a result of a decrease in the capacity of the stabilizing system of the spine. ${ }^{6}$ Therefore, the increased size of the neutral zone is a better indicator of lumbar instability than the increased total ROM of the lumbar segment. Based on this theory, segmental instability may be defined as a decrease in the capacity of the stabilizing system of the spine to maintain the spinal neutral zones within physiological limits. ${ }^{6}$

Three subsystems are responsible for maintaining stability, namely passive, neural, and active subsystems. The passive subsystem consists of the spine and parts of the spinal joints; the neural subsystem receives information from the structures of the passive and active subsystems, and it stabilizes the lumbar spine by controlling the function of the active subsystem, namely the muscles. "The neural and active subsystems are primarily responsible for spinal stability in the neutral zone." The members of the active subsystem can be divided into two groups: global and local stabilizer muscles. The global stabilizer muscles play an important role in performing the movements of the trunk and the hips, while the unique function of the local stabilizer muscles is the stabilization of the segments in relation to each other.' Generally local stabilizers include all the deep layer muscles such as lumbar multifidus, transversus abdominis, pelvic floor muscles, and diaphragm.' The stabilizing function of these deep muscles can be realized in a variety of ways. Lumbar multifidus has an important role in the segmental control mainly during lifting and rotational movements. ${ }^{5}$ Transversus abdominis muscle attaches to the thoracolumbar fascia; therefore, it is capable of increasing the stiffness of the lumbar spine indirectly. The pelvic floor muscles and diaphragm are in synergism with transversus abdominis, and they are responsible for maintaining and increasing intraabdominal pressure during several postural tasks. ${ }^{10}$ Hodges and Gandevia ${ }^{11}$ presumed in a previous study that a possible explanation for the mechanism of the stabilizing function of the diaphragm and pelvic floor muscles is the following: the activation of transversus abdominis prior to the initiation of an upper limb movement results in the displacement of the abdominal contents; hence, the consequential contraction of the diaphragm and pelvic floor muscles is necessary to restrain the shift of these abdominal structures. In their research, they assessed the activation of the diaphragm and transversus abdominis muscle during repetitive arm flexions in standing position. Contrary to their hypothesis, they found that the activation of diaphragm occurs prior to an arm movement and happens simultaneously with the activation of

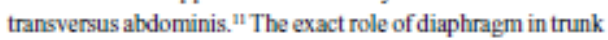
stabilization has been under investigation for $>50$ years, but the accurate mechanism still remains poorly understood. ${ }^{12}$ There have been several types of research which investigated the functioning of trunk stabilizer muscles during upper limb movement in standing position. ${ }^{13-15}$ However, there have been few research considering the sitting position. ${ }^{11,16}$

The importance of using non-pharmacological treatments, such as physical exercises, to reduce the intensity of low back pain is well known. ${ }^{17}$ However, to date, there has been no unitary exercise training program or any well-established complex solution to the problem, and there is a huge gap between evidence and practice. ${ }^{17}$ There is no consensus even in the national guidelines. ${ }^{\text {I }}$ Previous studies specified the impact of several types of training on CLBP, but a diaphragm strengthening training has not been tested yet as a solution to it. Ki et al ${ }^{1 \mathrm{Is}}$ measured the effect of forced breathing exercises on lumbar stability. They prowed that forced breathing exercises may improve lumbar stability in case of low back pain, ${ }^{15}$ but the role of breathing exercises in the background of the mechanism of improved lumbar stability was not clarified by this study. Janssens et al ${ }^{10}$ proved that the postural stability of the trunk can be improved by strengthening the diaphragm muscle and suggest that pain intensity may be decreased by diaphragm training. They strengthened the diaphragm with a POWERbreathe device that provides resistance to 
inhalation. Their training program lasted for 8 weeks, and the displacement of the center of the pressure was assessed by using a force plate. Pain intensity was measured with the Oswestry Disability Index. They found that the 8-week-long intensive diaphragm training increased respiratory muscle strength, that proprioceptive use changed in a positive way, and that the participants reported a decrease in low back pain severity. ${ }^{10}$ They presumed that their training program had an effect on the muscles other than diaphragm as well and may have improved the stabilization of the trunk. ${ }^{19}$ However, the changes that may have occurred as a result of the diaphragm strengthening training in the musculature and the mechanisms that provided the improvement of lumbar stabilization were not identified in their research

The aim of this study was to assess the effects of an 8-week-long diaphragm training on low back pain and not only on thickness of the diaphragm but also on that of other stabilizer muscles like transversus abdominis and lumbar multifidus muscle.

\section{Materials and methods}

\section{Subjects}

A total of 52 people participated voluntarily in our study with a history of chronic nonspecific low back pain while two of them withdrew their participation. The inclusion criterion was low back pain lasting for at least 3 months. Participants were asked not to have any other treatment during the time of the training, and they were required to be able to learn the usage of the diaphragm trainer and to be able to get to the location of the training. Exclusion criteria were the following: diagnosed specific causes of low back pain, balance problems of neurological origin, malignant tumors, serious ongan diseases, respiratory diseases, previous surgical interventions affecting the trunk or the limbs and the subjects being uncooperative. The participants were asked to indicate immediately if an acute inflammatory disease occurred. Based on these exclusion criteria, three subjects were excluded. All participants gave their written informed consent. The study is in compliance with the principles of the Declaration of Helsinki and was approved by the National Medical Research Council (identification number: 21416-2/2017/EKU). The trial was registered on www.clinicaltrials.gov (identification number: NCT03600207)

\section{Study design}

Grouping

This study was a randomized controlled trial which took place from September to Decernber 2017. The participants were divided (www.randomizer org) into two groups randomly: diaphragm training group (DT, $\mathrm{n}=26$ ) and control group (C, $\mathrm{n}=21$ ). The members of group $\mathrm{C}$ took part only in a complex training, while the members of group DT performed the complex training enhanced by diaphragm training. A flowchart of the study design can be seen in Figure 1. There were no significant differences between the groups regarding age, body mass index, and the duration of low back pain. The comparison of the main characteristics of the groups are summarized in Table 1.

\section{The training method}

Both the groups had an 8-week-long complex training, which was done twice per week, with 60 minutes duration (the details of the complex training are included in the Supplementary material). The members of groups $\mathrm{C}$ and DT participated in the same exercise program during the complex training. Besides this, group DT used a POWERbreathe Medic Plus (POWERbreathe Ltd, Warwickshire, UK) device twice a day at bome, 30 inhalations per occasion, and with the speed of 15 inhalations/min in addition to the complex training. The device was also used when trunk muscle strengthening exercises were performed during trainings. Using this device, members of group DT inhaled against resistance. The subjects were educated about the proper use of the POWERbreathe Medic Plus device during the first session. Before the training, a baseline assessment was conducted in group DT: maximal inhalation pressure (MIP) was measured with a POWERbreathe $\mathrm{KH} 2$ (POWERbreathe Ltd) device to determine the magnitude of resistance during training. The resistance was set individually to the value of $60 \%$ of the MIP

\section{Measurements}

Pain intensity was assessed with the visual analog scale (VAS). ${ }^{20}$ VAS is a unidimensional measure of pain intensity, which has been widely used in diverse adult populations. ${ }^{21}$ It is a continuous scale comprised of a borizontal line $10 \mathrm{~cm}$ in length. The scale is anchored by "no pain" (score of 0) and "worst imaginable pain" (score of 10). A higher score indicates greater pain intensity. ${ }^{21}$ Test-retest reliability is $\operatorname{good}(r=0.94, P<0.001){ }^{2 x}$ VAS scores are shown to correlate highly with other pain measure scores ( $r=0.62-0.91$ ), and they are sensitive to measuring changes in pain associated with treatment or time. ${ }^{2}$

The thickness of the stabilizer muscles' belly was measured with B-mode ultrasonography. By using a Zonare ZOne Ultrasound System (ZONARE Medical Systems, Inc., Mountain View, CA, USA; 2013), the thickness of transversus 


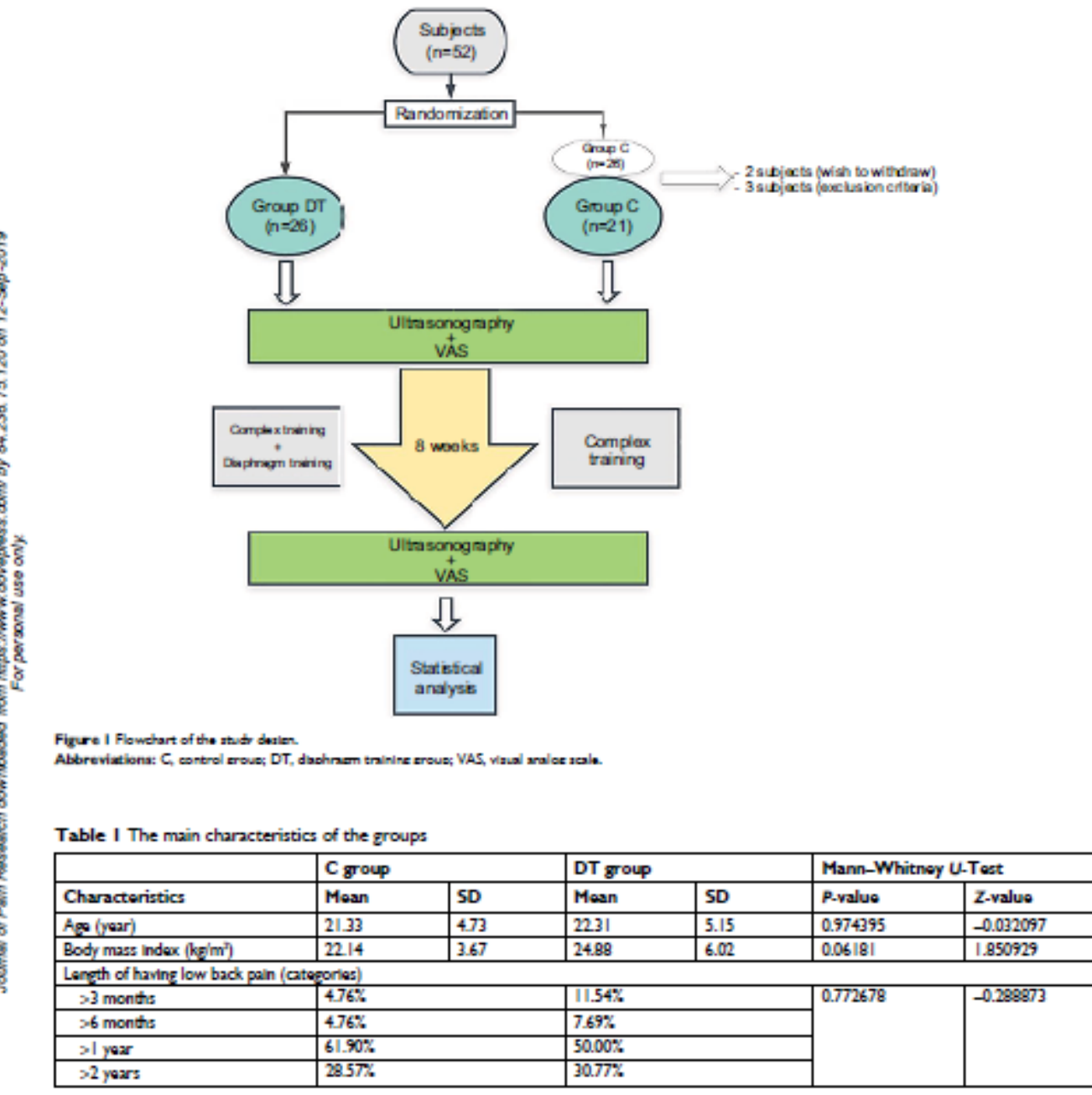

Abbreviationt $C$, consol arous: $D T$, daphnem trainine erova.

abdominis, lumbar multifidus, and diaphragm muscles were recorded in two different positions: in lying and in sitting positions (Figure 2). The positions of the transducers can be further seen in Figure 3. All the muscles were measured in two different states: in a relaxed and in a contracted state. When a clear image of the measured muscles was seen, it was frozen on the screen and saved. The thickness of the muscles' belly was measured on the saved pictures. Three pictures of one muscle in one position and state were taken. A total of
48 pictures of each participant were taken before the training and also 48 pictures after the training program. To ensure the same setting for ultrasonography, the skin surface was constantly marked, and the measurement was carried out by the same person with experience in ultrasonography. Test-retest reliability was tested by calculation of intra-class correlation and the reliability coefficient. Both the high interclass correlations (0.991-1) and the small repeatability coefficients (0.008-0.095) showed good reliability. 

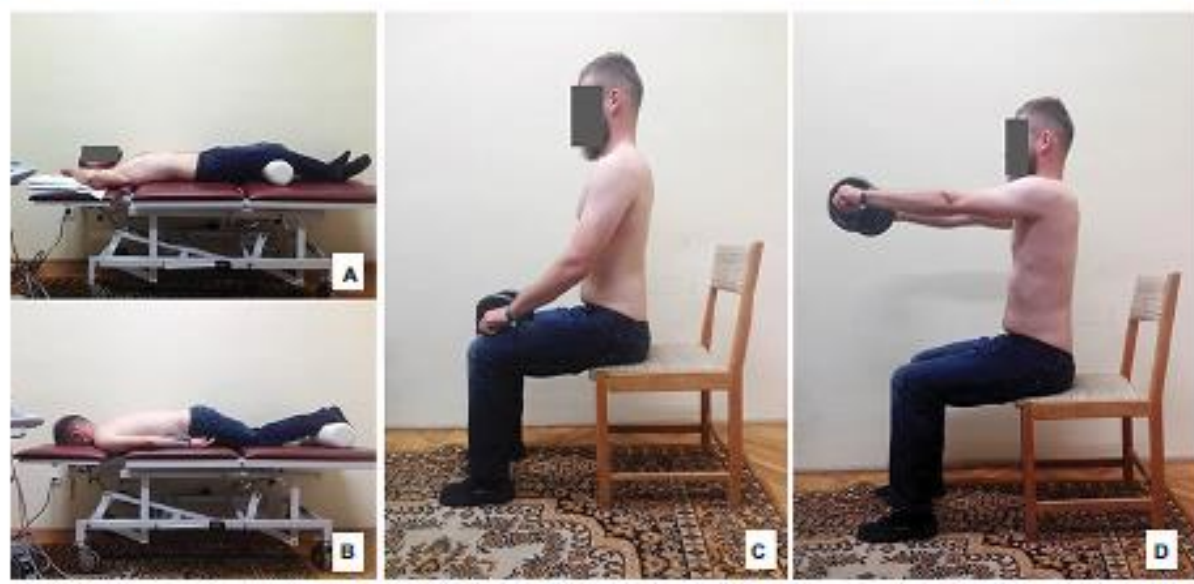

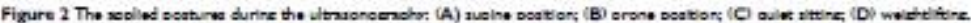

A
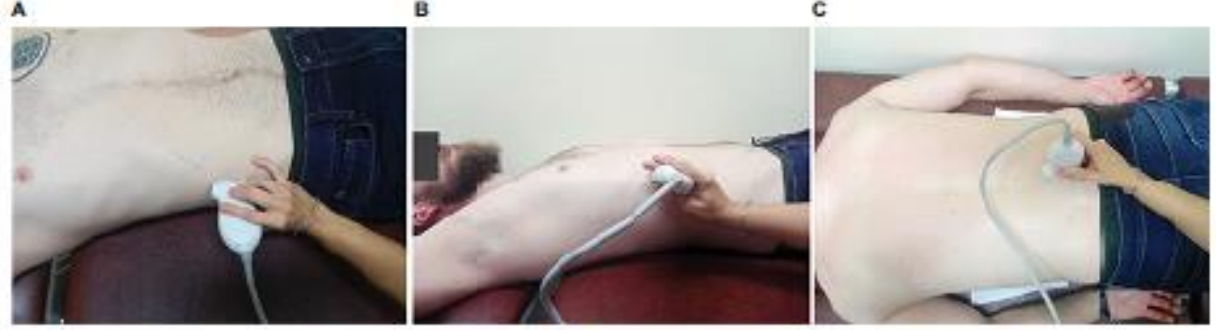

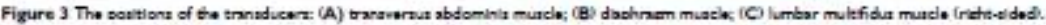

In case of transversus abdominis and diaphragm muscle, the subject was in a supine position with hips and knees flexed during the assessment (Figure 2A). Whereas in the case of the lumbar multifidus muscle, the subject was in a prone position with flexed knees and the lumbar spine was positioned into flexion by a small pillow placed under the abdomen (Figure 2B). Also, the knees were supported by a small pillow, providing $-30^{\circ}$ flexion. All muscles were assessed in a sitting position as well: during holding the sitting posture (Figure 2C) and during a weightlifting task (Figure 2D). The subjects were sitting on a chair without back support with hips and knees flexed in $90^{\circ}$ and their feet were on the floor. The neutral position of the trunk was set, and the participants were asked to bold this position during the examination. The subjects were sitting calmly but the stabilizer muscles were active to maintain the vertical position, so the so-called relaxed state was just a relatively relaxed state (Figure $2 \mathrm{C}$ ).
To achieve a more contracted state of the stabilizer muscles in the sitting position, a weightlifting activity was applied while holding the neutral position of the trunk. One dumbbell was used for the lifting procedure, and it was held with both hands (Figure 2D). The participants had to lift the weight forward to the height of the shoulders with extended elbows and maintain this position until the ultrasonography was performed (about 2 seconds) and repeat this maneuver as many times as was needed to assess the muscles. The patients were asked not to change the height of the lifting to ensure the same conditions. ${ }^{\text {In }}$ The weight to be lifted was chosen based on the subjective, perceived difficulty of the task: the subjects had to be able to lift it 13 times with short rests (about 5 seconds) between them. Thirteen repetitions were determined because the first lifting was a testing procedure when we could correct the height of the lifting and the posture of the trunk if that was necessary. Then three pictures of the assessed muscles 
were taken (three of transversus abdominis, three of the leftand three of the right-sided lumbar multifidus, and three of diaphragm muscle). When a neutral trunk posture was held in sitting position, it was defined as a relatively relaxed state, whereas lifting the weight in neutral trunk posture caused a relatively contracted state. Transversus abdominis muscle was assessed during tidal inhalation while diaphragm muscle was assessed during tidal exhalation to minimize the respiratory function of these muscles. The methodology of the ultrasound assessments is summarized in Table 2

\section{Data collection and analysis}

When using the VAS, the participants had to mark the average severity of lumbar pain on a $10-\mathrm{cm}$-long line. ${ }^{20}$ The scale is anchored by "no pain" (score of 0 ) and "worst imaginable pain" (score of 10). The distance of their mark from the zero point in cm-s was defined as the severity of the pain. ${ }^{21}$ For the comparison of the pain intensity, average values were calculated by group (mean $\pm \mathrm{SD}$ ). To compare the change between the before and after data, Wilcoxon matched pairs test was used

\section{Ultrasound data analysis}

Statistical calculations were performed with STATISTICA 13.1 (TIBCO Software Inc., Palo Alto, CA, USA) and IBM SPSS Statistics 24 software (IBM Corporation, Armonk, NY, USA). Test-retest reliability of the ultrasound imaging was checked by intra-class coefficients. The Shapiro-Wilk test was used as normality test. To compare the change between the before and after data, a two-way repeated measures ANONA mixed model was performed where the three repetitions were also taken into account. Results are given as estimated marginal means with their standard errors. To avoid significant changes by occasion, individual $P$-values were corrected by the step-down Bonferroni.

\section{Results}

\section{Severity of pain}

Both the groups showed significant improvement $(P<0.01)$ with regard to pain after the training. In group $C$, the average intensity of pain was $5.75( \pm 1.68)$ initially and after the training it changed to $2.14( \pm 1.9)(P=0.000219)$, which shows

Table 2 Measurement procedures of the ultrasound assessment

\begin{tabular}{|c|c|c|c|c|c|}
\hline \multirow[t]{2}{*}{$\mathbf{M}$} & \multirow{2}{*}{$\begin{array}{l}\text { Specification } \\
\text { Contraction state }\end{array}$} & \multicolumn{2}{|l|}{ Lying } & \multicolumn{2}{|l|}{ Sitting } \\
\hline & & Relaxed & Contracted & $R$ rolaxed & $R$ contracted \\
\hline \multirow[t]{6}{*}{$\begin{array}{l}\text { Transwersus abdomints } \\
\text { mensurement } \\
\text { procedure" }\end{array}$} & Poation & $\begin{array}{l}\text { Supine, lying } \\
\text { quietly }\end{array}$ & $\begin{array}{l}\text { Supine, contraction of the } \\
\text { abdomen, wethout lfteng } \\
\text { the head }\end{array}$ & $\begin{array}{l}\text { Wolght resting } \\
\text { on the thighs }\end{array}$ & Woightifiting \\
\hline & Breaching state & Tidal inhalation & Forced exchalation & Tidal inhalation & \\
\hline & Type of transducer & \multicolumn{4}{|l|}{ Linear } \\
\hline & Transducer placement & \multicolumn{4}{|c|}{ Right mid-2xdlary Ino betwoen the pelvis and the costal murgin } \\
\hline & Transducer bandwidth & \multicolumn{4}{|l|}{$10-5 \mathrm{MHz}$} \\
\hline & Calper placing & \multicolumn{4}{|c|}{ Inside the hyperechoic connective tissue layers } \\
\hline \multirow[t]{6}{*}{$\begin{array}{l}\text { Dephragm massurement } \\
\text { procedurept }\end{array}$} & Poation & \multicolumn{2}{|l|}{ Supine, lying quisty } & $\begin{array}{l}\text { Weight resting } \\
\text { on the thighs }\end{array}$ & Woightilfting \\
\hline & Broxthing state & Tidal exhalation & $\begin{array}{l}\text { Forced inhalation - } \\
\text { POWERbreathe } \mathrm{KH} 2\end{array}$ & \multicolumn{2}{|l|}{ Tidal exhalation } \\
\hline & Type of transducar & \multicolumn{4}{|l|}{ Linear } \\
\hline & Transducer placement & \multicolumn{4}{|c|}{$\begin{array}{l}\text { Right anterior adllary line, elfhth or ninth intercostal space wethout encroaching on the } \\
\text { lung during inspiration }\end{array}$} \\
\hline & Transducer bandwidth & \multicolumn{4}{|l|}{$10-5 \mathrm{MHz}$} \\
\hline & Calper placing & \multicolumn{4}{|c|}{ Hyposchoic layer between the hyperechoic lines of pleural and peritoneal fascla } \\
\hline \multirow[t]{6}{*}{$\begin{array}{l}\text { Lembar multufidss } \\
\text { mensurement procedure" }\end{array}$} & Poation & Prone, lying quistly & $\begin{array}{l}\text { Prone, liting the head and } \\
\text { the shoulders } 5 \mathrm{~cm} \text { high }\end{array}$ & $\begin{array}{l}\text { Weight resting } \\
\text { on the thighs }\end{array}$ & Woightilfing \\
\hline & Breaching state & \multicolumn{4}{|l|}{\begin{tabular}{|l|l|l|l|l|l} 
Irrelant \\
\end{tabular}} \\
\hline & Type of transducer & \multicolumn{4}{|l|}{ Curvod } \\
\hline & Transducer placement & \multicolumn{4}{|c|}{$\begin{array}{l}\text { Left and right side of the lumbar ares, longttudinally on the spine, moved lateraly so that a } \\
\text { parasagttal Inuge of multtfidus could be taken }\end{array}$} \\
\hline & Transducer bandwidch & \multicolumn{4}{|l|}{$6-2 \mathrm{MHz}$} \\
\hline & Calper placing & \multicolumn{4}{|c|}{$\begin{array}{l}\text { On the posterior-most portion of the L4/5 facet /oint and the plane between the muscle } \\
\text { and subcutansous tissus }\end{array}$} \\
\hline
\end{tabular}


a $62 \%$ decrease. In the group DT, the average intensity of Ultrasound assessment

pain was $5.70( \pm 1.74)$ before the treatment, whereas after the The results of the statistical comparison are summarized 8-week-long training it was only $2.62( \pm 1.89)(P=0.000017), \quad$ in Table 3 . The estimated means and standard errors of the so the decrease is $54 \%$.

ultrasound assessment data are shown in Figures 4-9.

Table 3 The results of the statistical comparison

\begin{tabular}{|c|c|c|c|c|c|c|c|c|}
\hline \multicolumn{5}{|c|}{ Group C $(n=2 I)$} & \multicolumn{4}{|c|}{ Group DT $(n=26)$} \\
\hline Variable & Mean & SE & \begin{tabular}{|l|} 
P-value \\
(ANOVA)
\end{tabular} & $\begin{array}{l}\text { P-value after } \\
\text { Bonferroni- } \\
\text { Holm }\end{array}$ & Mean & SE & \begin{tabular}{|l|} 
P-value \\
(ANOVA)
\end{tabular} & $\begin{array}{l}\text { P-value after } \\
\text { Bonforroni- } \\
\text { Holm }\end{array}$ \\
\hline \multicolumn{9}{|c|}{ Tranewersus abdominita_relaxed state } \\
\hline $\begin{array}{l}\text { Before } \\
\text { After }\end{array}$ & $\begin{array}{l}0.280 \\
0.311\end{array}$ & $\begin{array}{l}0.017 \\
0.019\end{array}$ & $0.018^{*}$ & 0.320 & $\begin{array}{l}0.307 \\
0.343\end{array}$ & $\begin{array}{l}0.018 \\
0.018\end{array}$ & $0.002^{+4}$ & $0.041^{*}$ \\
\hline \multicolumn{9}{|c|}{ Traneverses abdominis_contracted state } \\
\hline $\begin{array}{l}\text { Before } \\
\text { After }\end{array}$ & $\begin{array}{l}0.607 \\
0.707\end{array}$ & $\begin{array}{l}0.031 \\
0.054\end{array}$ & $0.012^{*}$ & 0.243 & $\begin{array}{l}0.633 \\
0.737\end{array}$ & $\begin{array}{l}0.037 \\
0.047\end{array}$ & $0.004^{4+4}$ & 0.092 \\
\hline \multicolumn{9}{|c|}{ Traneversus abdominit__relattrely relaxed state } \\
\hline $\begin{array}{l}\text { Beforo } \\
\text { After }\end{array}$ & \begin{tabular}{|l|}
0.381 \\
0.408
\end{tabular} & $\begin{array}{l}0.022 \\
0.048\end{array}$ & 0.538 & 1 & $\begin{array}{l}0.419 \\
0.514\end{array}$ & $\begin{array}{l}0.040 \\
0.049\end{array}$ & $0.000^{\mathrm{Ht}}$ & $0.003^{* 4}$ \\
\hline \multicolumn{9}{|c|}{ Tranceversus abdominte_relathely contracted state } \\
\hline $\begin{array}{l}\text { Before } \\
\text { After }\end{array}$ & \begin{tabular}{|l|}
0.466 \\
0.565
\end{tabular} & $\begin{array}{l}0.031 \\
0.082\end{array}$ & 0.174 & 1 & $\begin{array}{l}0.488 \\
0.555\end{array}$ & $\begin{array}{l}0.051 \\
0.057\end{array}$ & $0.042^{4}$ & 0.712 \\
\hline \multicolumn{9}{|c|}{ Dlaphragm_relaxed state } \\
\hline $\begin{array}{l}\text { Before } \\
\text { After }\end{array}$ & $\begin{array}{l}0.127 \\
0.131\end{array}$ & $\begin{array}{l}0.010 \\
0.009\end{array}$ & 0.414 & 1 & $\mid \begin{array}{l}0.131 \\
0.155\end{array}$ & $\begin{array}{l}0.008 \\
0.010\end{array}$ & $0.001^{+4}$ & $0.016^{*}$ \\
\hline \multicolumn{9}{|c|}{ Dlachragm_contracted state } \\
\hline $\begin{array}{l}\text { Before } \\
\text { After }\end{array}$ & $\begin{array}{l}0.162 \\
0.170\end{array}$ & $\begin{array}{l}0.012 \\
0.017\end{array}$ & 0.550 & 1 & $\begin{array}{l}0.141 \\
0.225\end{array}$ & $\begin{array}{l}0.009 \\
0.016\end{array}$ & $0.000^{* 4}$ & $0+4$ \\
\hline \multicolumn{9}{|c|}{ Dlaphragm_relatively relaxed state } \\
\hline $\begin{array}{l}\text { Defore } \\
\text { After }\end{array}$ & $\begin{array}{l}0.192 \\
0.173\end{array}$ & $\begin{array}{l}0.013 \\
0.014\end{array}$ & $0.012^{*}$ & 0.243 & $\begin{array}{l}0.178 \\
0.181\end{array}$ & $\begin{array}{l}0.009 \\
0.010\end{array}$ & 0.728 & 1 \\
\hline \multicolumn{9}{|c|}{ Dlaphragm_relatively contracted state } \\
\hline $\begin{array}{l}\text { Before } \\
\text { After }\end{array}$ & $\begin{array}{l}0.206 \\
0.205\end{array}$ & $\begin{array}{l}0.017 \\
0.018\end{array}$ & 0.970 & 1 & $\begin{array}{l}0.176 \\
0.223\end{array}$ & $\begin{array}{l}0.011 \\
0.013\end{array}$ & $0.000^{* 4}$ & $0.001^{* 4}$ \\
\hline \multicolumn{9}{|c|}{ Lumbar multrfidus_(right alded)_relaxed state } \\
\hline $\begin{array}{l}\text { Before } \\
\text { After }\end{array}$ & \begin{tabular}{|l|}
2456 \\
2524
\end{tabular} & $\begin{array}{l}0.089 \\
0.178\end{array}$ & 0.635 & 1 & $\begin{array}{l}2509 \\
2.601\end{array}$ & $\begin{array}{l}0.107 \\
0.107\end{array}$ & $0.045^{*}$ & 0.717 \\
\hline \multicolumn{9}{|c|}{ Lumbar multrfidus_(right sided)_contracted state } \\
\hline $\begin{array}{l}\text { Before } \\
\text { After }\end{array}$ & $\begin{array}{l}3.349 \\
3.458\end{array}$ & $\begin{array}{l}0.100 \\
0.187\end{array}$ & 0.466 & 1 & $\begin{array}{l}3.185 \\
3.253\end{array}$ & $\begin{array}{l}0.132 \\
0.129\end{array}$ & 0.313 & 1 \\
\hline \multicolumn{9}{|c|}{ Lumbar multfidus_(laft sided)_rolaxed state } \\
\hline $\begin{array}{l}\text { Before } \\
\text { After }\end{array}$ & $\begin{array}{l}2363 \\
2447\end{array}$ & $\begin{array}{l}0.079 \\
0.190\end{array}$ & 0.595 & 1 & $\begin{array}{l}2.352 \\
2.554\end{array}$ & $\begin{array}{l}0.090 \\
0.109\end{array}$ & $0.000^{4+}$ & $0.004^{4+4}$ \\
\hline \multicolumn{9}{|c|}{ Lumbar multrfidus_(laft sided)_contracted state } \\
\hline $\begin{array}{l}\text { Before } \\
\text { After }\end{array}$ & $\begin{array}{l}3.337 \\
3.449\end{array}$ & $\mid \begin{array}{l}0.092 \\
0.191\end{array}$ & 0.468 & 1 & $\begin{array}{l}3.155 \\
3.318\end{array}$ & $\begin{array}{l}0.116 \\
0.131\end{array}$ & $0.011^{*}$ & 0.228 \\
\hline \multicolumn{9}{|c|}{ Lumbar muitfridus_(right sided)_relattvoly relaxed state } \\
\hline $\begin{array}{l}\text { Before } \\
\text { After }\end{array}$ & \begin{tabular}{|l|}
2494 \\
2627
\end{tabular} & \begin{tabular}{|l|}
0.071 \\
0.157
\end{tabular} & 0.326 & 1 & $\begin{array}{l}2.339 \\
2470\end{array}$ & $\begin{array}{l}0.086 \\
0.082\end{array}$ & $0.005^{+4}$ & 0.099 \\
\hline \multicolumn{9}{|c|}{ Lumbar multridus_(right sided)_relattvoly contracted state } \\
\hline $\begin{array}{l}\text { Before } \\
\text { After }\end{array}$ & $\begin{array}{l}3.059 \\
3.118\end{array}$ & $\begin{array}{l}0.098 \\
0.210\end{array}$ & 0.723 & 1 & $\begin{array}{l}2.670 \\
2873\end{array}$ & $\begin{array}{l}0.115 \\
0.110\end{array}$ & $0.002+4$ & $0.046^{+}$ \\
\hline \multicolumn{9}{|c|}{ Lumbar multridus_(lat sided)_relatively relawed state } \\
\hline $\begin{array}{l}\text { Before } \\
\text { After }\end{array}$ & $\begin{array}{l}2.544 \\
2694\end{array}$ & $\begin{array}{l}0.077 \\
0.17\end{array}$ & 0.347 & 1 & $\begin{array}{l}2316 \\
2474\end{array}$ & $\begin{array}{l}0.102 \\
0.094\end{array}$ & $0.002 *$ & $0.044^{*}$ \\
\hline \multicolumn{9}{|c|}{ Lumbar multrfidus_(lett sided)_relatively contracted state } \\
\hline $\begin{array}{l}\text { Before } \\
\text { After }\end{array}$ & $\begin{array}{l}3.142 \\
3.168\end{array}$ & $\begin{array}{l}0.143 \\
0.146\end{array}$ & 0.673 & 1 & $\begin{array}{l}2624 \\
2833\end{array}$ & $\begin{array}{l}0.126 \\
0.106\end{array}$ & $0.001^{*}$ & 0.0394 \\
\hline
\end{tabular}

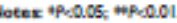

Abtreviations: $\mathrm{C}$, control; DT, dashrom tainins, SE, randard error 
The results of the ultrasound assessment for the transversus abdominis muscle showed no significant differences in group $\mathrm{C}$ in supine position during relaxed and contracted state. In case of group DT, significant increase in thickness was found in the relaxed state $(P<0.05)$, but there were no significant changes in the contracted state in supine position (Figure 4).

In sitting position, there were no differences between the before and after data in group C. On the contrary, in case of group DT, the thickness of transversus abdominis muscle increased significantly in the relatively relaxed state ( $P<0.01$ ). However, there were no significant changes in the relatively contracted state (Figure 5)

With regard to the diaphragm muscle's thickness, in supine position, there were no notable changes in case of group $\mathrm{C}$ in either state. On the other hand for group DT, significant increase was found in the thickness of the muscle belly both in the relaxed $(P<0.05)$ and in the contracted states $(P<0.01)$ after the training (Figure 6).

For the functional sitting position, there were no notable changes in the relatively relaxed and the relatively contracted state in group $\mathrm{C}$, with regard to the thickness of diaphragm. In contrast, group DT showed a significant increase in the relatively contracted state $(P<0.01)$ but not in the relatively relaxed state (Figure 7).

In case of the relaved and contracted states of the leftand right-sided lumbar multifidus, there were no substantial changes found in group $\mathrm{C}$ in prone position. For group DT, significant increase was only found in the left-sided muscle in the relaxed state $(P<0.01)$. There were no notable changes either in the relaxed and or the contracted states of the rightsided multifidus or in the contracted state of the left-sided lumbar multifidus muscle (Figure 8).

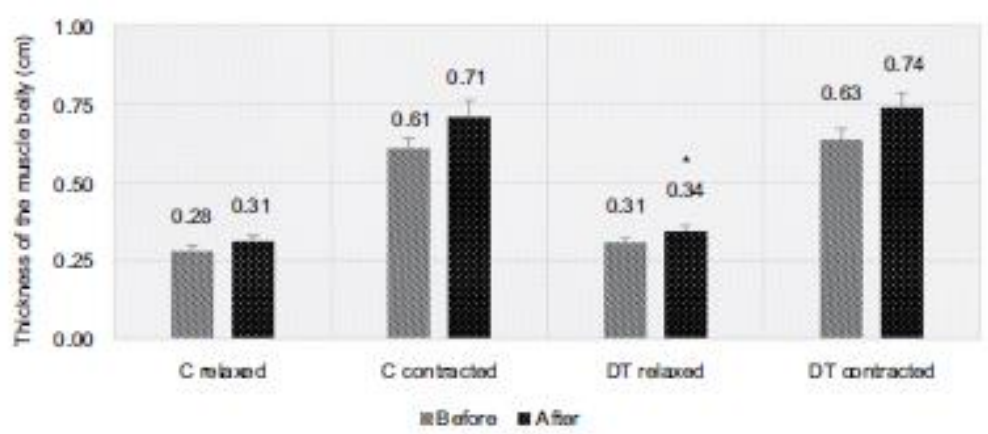

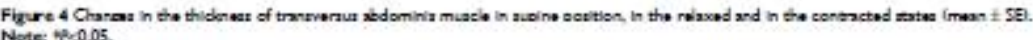
Note: $\$$ p.0.05.

Abbreviztions: C, conterol srous; DT, dashnem trainine erous; SE, sandard wrror.

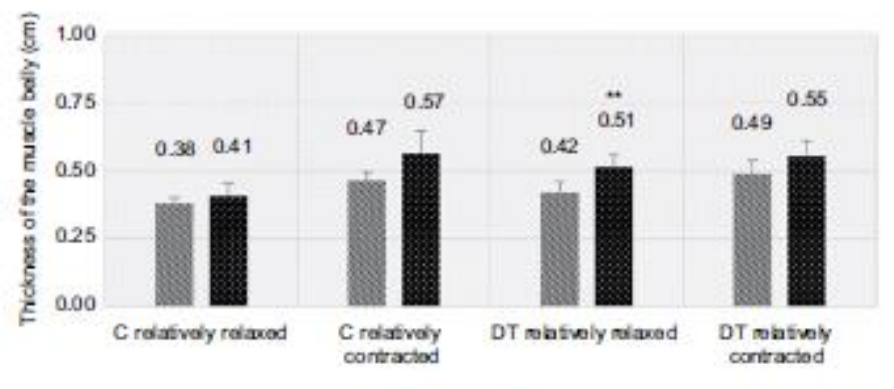

aBoroos . Afar

Figures Chane

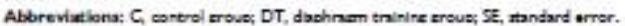




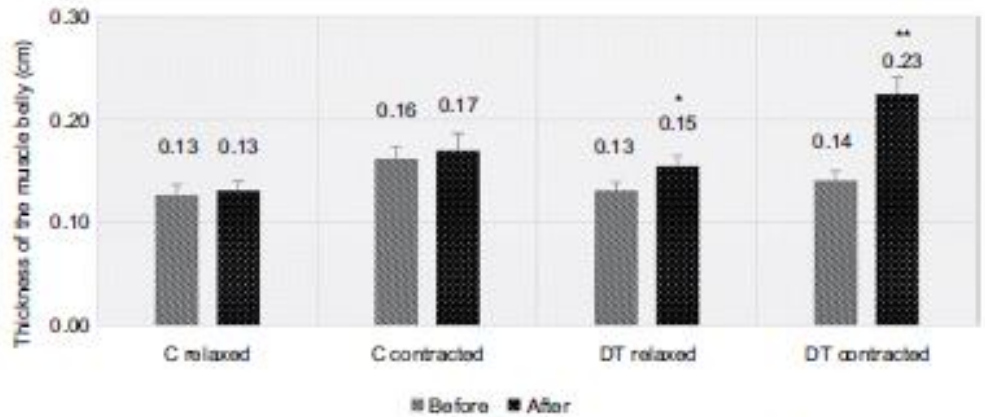

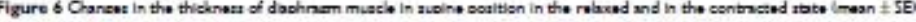

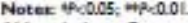

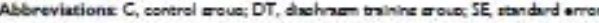

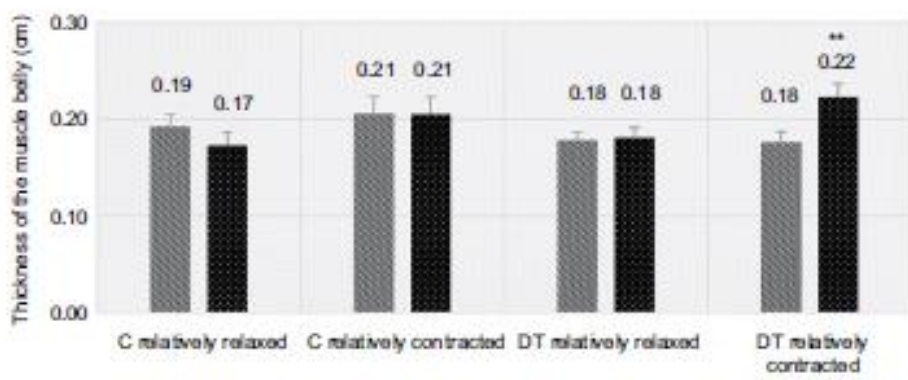

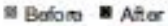

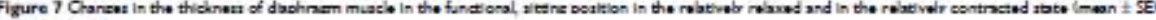
Note + +HP.0.01.

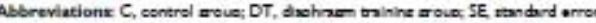

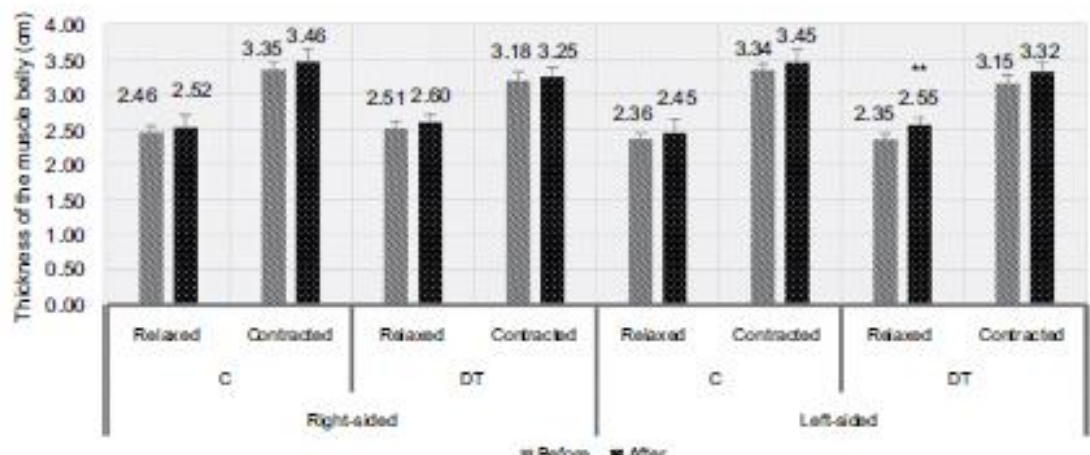

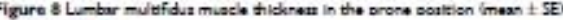


In the sitting position, there were no significant differences between the before and after data in group $\mathrm{C}$ in any states of lumbar multifidus muscle. For group DT, significant increases were found in the relatively contracted states $(P<0.05)$ in bilateral lumbar multifidus muscles as well as in the left-sided multifidus in the relatively relaxed state ( $P<0.05)$. Regarding the right-sided multifidus muscle in the relatively relaxed state, there were no notable changes in the thickness of the muscle in the sitting position with regard to group DT (Figure 9).

\section{Discussion}

The main finding of the study is that complex training completed with diaphragm training increased the thickness not only of the diaphragm but also of the other stabilizer muscles such as transversus abdominis and multifidus muscle. The significant increase in diaphragm muscle thickness in supine position indicates the effectiveness of diaphragm training $\mathrm{g}^{2}$ in a position where the other stabilizers are relaved. Both of the applied training methods resulted in significant improvement in pain. However, it was more significant in case of group C whose metnbers participated only in the complex training. With regard to the thickness of the lumbar stabilizer muscles in group $\mathrm{C}$, there were no significant changes in any of the muscles resulting from the 8-week-long intervention, which suggests that diaphragm strengthening training can provide extra benefits.

Regarding the intensity of pain, both the training methods resulted in significant improvernent although it was more significant in group C. The members of the groups took part in the same complex training with the same exercises. However, the members of group DT faced a more difficult situation: they had to do the strengthening exercises parallel with the diaphragm strengthening training. Pain perception is highly subjective, which is influenced by several psychological and emotional factors. ${ }^{27.4}$ Intensive strengthening exercises taken for a short period of time are not always very effective in reducing pain intensity. ${ }^{2}$ Many factors (fear, structural abnormality, pain, posture reduction, etc) maintain the vicious cycle in CLBP; if intervention is capable of reducing one of the maintaining factors, the vicious cycle may be broken. ${ }^{2427}$ Both the trainings decreased pain significantly and the complex training completed with diaphragm training increased the thickness of stabilizer muscles generating change in the condition of transversus abdominis, diaphragm, and lumbar multifidus muscles. Based on our results, it can be stated that pain perception seerns to have been influenced positively by the interventions, so it can be a possible way to influence the vicious cycle underlying CL.BP.

The exercises of our complex training program were the same in the two study groups. The training consisted of static and dynamic strengthening exercises for the trunk and hip muscles as well as proprioceptive training. All strengthening exercises were performed using external resistance (dumbbells, resistance bands, and medicine ball) or body weight. A 
double-blind, randomized controlled trial proved earlier that both motor control and general exercises increase the thickness of lumbar multifidus and transversus abdominis muscle significantly in the case of low back pain patients as a result of an 8-week-long training program. ${ }^{\mathrm{x}}$ A previous study also showed that the thickness of diaphragm muscle increases as a consequence of a 4-week-long diaphragm training ${ }^{22}$ Based on the abovementioned findings and considering our results, we can conclude that our complex training completed with a diaphragm strengthening training is a possible way to increase the thickness of transversus abdominis, diaphragm, and lumbar multifidus muscles.

In case of group DT, the thickness of transversus abdominis muscle increased significantly in the relaxed state (calm lying) but not in the contracted state when the subjects were asked to contract their abdominal muscles in supine position. We found similar muscle changes in the sitting position where the thickness of transversus abdominis muscle increased significantly in the relatively relaxed state when the sitting position was beld, but there were no notable changes during the weightlifting task in the relatively contracted state. The increase of the thicknesses in relaxed and relatively relaxed states may have occurred due to the effect of our interven-

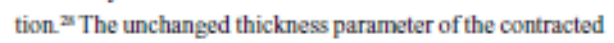
state in the supine position maybe due to the limitation of our measurement procedure: the participants were asked to contract their abdominal muscles voluntarily without lifting their head or shoulders from the bed. This kind of contraction seems to be more dependent on the compliance of the participants. ${ }^{20,30}$ Moreover, this movement was not practiced during our program; therefore, the quality of the performance may have been diverse ${ }^{n}$ and may not have been sufficient enough to show the effectiveness of the training. In addition, transversus abdominis muscle is a local stabilizer whose main function is more of stabilization and not implementation of movements, ${ }^{1,9}$ and in supine position, the demand for stabilization is minimal. ${ }^{31,3}$ There was no significant change in the thickness of transversus abdominis in the relatively contracted state either when the weightlifting was performed. It is well known that lifting tasks activate mainly the extensor group. ${ }^{16,33}$ Our results provide further evidence that lumbar multifidus has a more enhanced role in performing a weightlifting task, than transversus abdominis muscle. Therefore, the applied weightlifting task may not be the most appropriate postural task to show the enhanced stabilizer function of transversus abdominis muscle.

The increased thickness of diaphragm muscle in relaxed and in contracted states in the supine position may show the effectiveness of the diaphragm strengthening training. ${ }^{2}$ The results show that the only condition where we could not find any increase in the thickness of diaphragm after the training was the relatively relaxed state in sitting position. This finding may be explained by the neutral vertical position of the trunk which was beld only against gravity in this case. This posture does not require more enhanced stabilization from diaphragm muscle. ${ }^{10 x}$ Significant increase occurred in the thickness of diaphragm muscle when the weightlifting was performed, in the relatively contracted state. Movements of the upper limb challenge the diaphragm muscle as a stabilizer muscle more contrary to the simple tasks to maintain vertical position. ${ }^{10}$ In a previous study, Hodges et al assessed the functioning of diaphragm during a rapid movement of the arm. Their findings proved that increased activity of diaphragm occurs during this motion. ${ }^{n}$ The diaphragm of low back pain patients has an altered postural function compared to healthy subjects when isometric flexion against resistance of the upper or lower limb was applied. ${ }^{3}$ In our training program, several resistance exercises were performed by the upper limb when the vertical posture of the trunk needed to be held, and the participants used the POWERbreathe device in parallel with upper limb exercises. Our results show that there is an increased thickness of diaphragm during the lifting task after training which may suggest that the role of diaphragm muscle has improved in maintaining trunk stability during upper limb activities as a result of the applied 8-week-long training. Our findings are in line with a previous study of Dulger et al ${ }^{36}$ They found that as a result of a stabilization exercise program, the thickness of diaphragm increased as well as the stability of the lumbar spine. ${ }^{36}$

Considering lumbar multifidus muscle in prone position, significant increase was found only in case of the left-sided one in the relaxed state. There were no significant changes in case of contracted states of the left-sided muscle or in both states of the right-sided multifidus. Like in case of transversus abdominis, the main function of lumbar multifidus is not implementation of movements but the segmental stabilization of the lumbar spine as it produces compression with minimal movement torque. "This may be the reason for the unchanged thickness in the contracted state, when the patients were asked to lift their head and shoulders from the bed. The role of lumbar multifidus muscle in stabilization is highlighted in rotational movements and therefore in movements of the contralateral limb" Every participant was right-handed in our study which might have influenced the training effects: our results revealed that in prone position, the left-sided (contralateral to the dominant arm) muscle thickness improwed 
significantly in the relaxed state. The resistance exercises were probably more effectively performed with the dominant (right-sided) arm. ${ }^{3}$ In sitting position, the thickness of both the left- and right-sided multifidus muscle increased in the relatively contracted state (during weightlifting) and the left-sided lumbar multifidus muscle thickness also increased in the relatively relaxed state as well (while holding the vertical position of the trunk). Contrary to the prone position when sitting, the postural demand is enhanced and lumbar multifidus muscle can act directly on the lumbar vertebra column producing the anti-flexion (extension) moment." During weightlifting (relatively contracted state), this anti-flexion moment of bilateral multifidus muscle is more important. "The increased thickness possibly occurred as a result of our training method. The only unchanged thickness in sitting position was found in the right-sided (ipsilatera to the dominant arm) lumbar multifidus muscle in relatively * relaxed state. The unchanged thickness may be explained by the influence of right-handedness on the training and/or on the testing procedure. In case of our testing procedure, one dumbbell was lifted with both the hands; therefore, it is possible that the dominant arm had a bigger contribution in the exercise. ${ }^{\text {x }}$ Further investigations using two dumbbells are needed to support this hypothesis.

The differences between groups DT and $\mathrm{C}$ in the change of the thickness of the stabilizer muscles indicate that diaphragm training has an extra advantage compared to a conventional complex training program. Further investigations are warranted to explore the mechanism behind the changes, but some possible assumptions can be made.

The effect of deep abdominal muscle exercises on respiratory function was assessed in a previous study. ${ }^{30}$ Deep abdominal muscles and diaphragm play an important role in maintaining and increasing the intra-abdominal pressure by their co-contraction. The finding of this research shows that enhanced diaphragmatic function achieved via deep abdominal muscle strengthening exercises did not only increase respiratory volume but also enhanced the stability of the lumbar spine through the co-contraction of transversus abdominis. ${ }^{30}$ Contrary to their above-mentioned training method, we have placed emphasis on the diaphragm muscle strengthening in our training program, but as a consequence, transversus abdominis muscle may be strengthened in this alternative, indirect way.

People with CLBP have a higher diaphragm position, a smaller diaphragm excursion, and greater diaphragm fatigability, ${ }^{3,42}$ which is compensated by increased lung volume to provide an adequate increase in intra-abdominal pressure. ${ }^{12}$ Diaphragm strengthening training is a viable method to enhance the excursion of the diaphragm and increase the mobility of the muscle. ${ }^{43,4}$ We assumed that a higher excursion of the diaphragm occurred due to the diaphragm strengthening training which further influenced the function of the diaphragm muscle during breathing and postural stabilization. ${ }^{10}$ Significant increases were found in the diaphragm thickness when the weightlifting task was performed in sitting position. The increased thickness during weightlifting suggests that the role of diaphragm muscle in maintaining trunk stability may have been improved.

Previous studies suggested that increase in the respiratory output causes an increased excursion of the body in space. ${ }^{45,26}$ Another previous study reported that normal inhalation is linked to the extension of the lumbar spine in standing posture. ${ }^{*}$ Significant changes in posture and significant enhancernent occurs in the activation of erector spinae muscle when the inspiration effort increases." The fact that our training combined exercises in vertical positions with forced inhalation exercises can explain the training effects especially the increase in the thickness of lumbar multifidus muscle in sitting posture.

\section{Limitations}

A limitation of this study is that by using ultrasonography we could not discriminate between the increase of muscle thickness as result of the changes of the tone and activation pattern and muscle hypertrophy which occurred as a result of the strengthening training. Another limitation of this study is the presumption that the compliance of the subjects was on the same level but it could not be controlled by objective methods. To assess transversus abdominis muscle in contraction in supine position, the patients were asked to contract their abdominal muscles voluntarily. This exercise needs a more developed understanding of the movement; therefore, we could not be sure that everyone performed the contraction on the same level. ${ }^{20.00}$ This procedure would have been better if we had allowed the flexion of the trunk to a specified extent. In case of sitting positions, the subjects were asked to hold the neutral position of the trunk which was controlled by a physiotherapist but not with objective methods. Therefore, some inclination of the trunk may have happened during the ultrasound measurement procedure. For further studies, the vertical position should be controlled in a more objective manner

\section{Conclusion}

In our randomized controlled study, the training effects of a complex training and a complex training completed with diaphragm training were examined. Based on our results, we suggest that the applied complex training completed with 
diaphragm strengthening training is an effective and viable way to increase the thickness of the stabilizer muscles of the lumbar spine such as transversus abdominis, diaphragm, and lumbar multifidus muscles. We can say that this training method is effective in reducing the severity of lumbar pain. However, complex training alone was more efficient taking the results of VAS into consideration. The results suggest that our complex training enhanced with diaphragm strengthening may be a viable therapeutic approach in the complex treatment of chronic nonspecific low back pain. Our findings clearly show that our intervention can have an influence on the diaphragm's postural function during upper limb lifting tasks. The mechanisms behind the effects of diaphragm training need to be understood more clearly; therefore, additional investigations are necessary. We suggest a further consideration focusing on whether diaphragm training alone would be a new therapeutic approach for those who are not capable of performing conventional exercises.

\section{Acknowledgment}

Edit Nagy and Tamás Bender share senior authorship.

\section{Disclosure}

The authors report no conflicts of interest in this work.

\section{References}

1. Dethey B. Lower back pain; 2013. Avilable from: http:/ www who int/medicines/areas/priority_medicines/BP6_24L.BP.pdf. Accessed Nowember 9, 2017.

2. Hoy D, March L, Brooks P, et al. The global burden of low back pein estimates from the Global Burden of Disease 2010 stady. Ann Rhewm Des. 2014;73(6):968-974.

3. Deyo RA, Weinstein JN. Low back pain. N Engl J Med. 2001;344(5): $363-370$.

4. Panjabi MM. Clinical spinal instability and low back pain. $J$ Electiomoogr Kinesiol. 2003;13(4):371-379.

5. Frit: JM, Frhurd RE, Hagen BE. Segmental Instability of the Lumbur Spine. Phys Ther. 1998;78(8):889-896.

6. Parjabi MM. The stabilizing system of the spine. Part II. Neutral zone and instability bypothesis. J Sptnal Dtond. 1992;5397(4):390-397 discussion.

7. Hodges PW, Moseley GL. Pain and motor control of the lumbapelvi region: effect and possible mechanisms. J Elecirumyogr Kinesiol 2000;:13(4):361-370.

8. Bruno P. The we of "stabilization exercises" to affect neuromuscula control in the hambopelvic region a narnative review. J Can Chirupr Assoc. 2014-58(2):119-130.

9. Macintosh JE, Bogduk N, Gnocovetsky S. The biomechanics of the thoncolumber fascis Clise Biomeck. 1987;2(2):78-83.

10. Hodges PW, Butler JE, Mckervie DK, Gandeviz SC. Contraction of the human diaphragm during rapid postural adjustments. $J$ Physsal 1997;:505 (Pt 2):539-545.

11. Hodges PW, Gandevia SC. Activation of the human diaphragm during a repetitive postural taxk $J \mathrm{Physial}$. 2000-522(Pt 1):165-175.

12. Kolar P, Suk 1, Kyncl M, et al. Stabilizing function of the diaphragm: dynamic MRI and synchronizod spirometric assessment. J Appl I hysiol. 2010-109(4):1064-1071.
13. Ning X, Thou J, Dei B, Jarid M. The assessment of material handling strategies in dealing with sudden laading; the effects of load handling position on trunk biomechanics. Appl Engon. 2014;45(6):1399-1405.

14. Thou $\perp$ Dai B, Ning X. The assessment of material handling strategies in dealing with syiden loading: influences of foot plycement on trunk biomechanies. Finanomisc 2013:56(10):1569-1576.

15. Sweeney N, O Sullivan C, Kelly G. Multifidus muscle sine and percent age thickness changes among patients with unilateral chronic low back pain (CL.BP) and healthy controls in prone and standing. Man Ther. 2014;19(5):433-439.

16. Yates JW, Karwowski W. An electromyographic analysis of seated and standing lifting tasks. Einganomics. 1992;35(7-8):889-898.

17. Foster NE, Anema JR, Cherkin D, et al. Prevention and treatment of low back pair evidence, challenges, and promising directions. I ancet. 2018:391(10137):2368-2383.

18. $\mathrm{KiC}, \mathrm{Heo} \mathrm{M}$, Kim HY, Kim EJ. The efferts of forced breathing exercise on the lumbar stabilization in chronic low back pin patients. J Phys Ther S-1. 2016:28(12):3380-3183.

19. Janssens L, Mcoonnell AK, Pijnenburg M, et al. Inspintory muscle training affects proprioceptive use and low back pain. Med Set Sperts Exer. 2015;47(1):12-19.

20. Huskisson EC. Measurement of pain. Lancet. 1974;304(7899); $1127-1131$

21. Hawker GA. Minn S, Kendzerska T, French M. Messures of adilt pair Visal Analog Scale for Pain (VAS Pain), Numeric Rating Scale for Pain (NRS Pain), MoGill Pain Orestionnaire (MPO), Short-Form MoGill Pain Ouestionnaire (SF-MPQ), Chronic Pain Grade Sale McGill Pain Questionnaire (SF-MPQ), Chronic Pain Grade Scale
(CPCS), Short Form-36 Bodily Pain Scale (SF-36 BPS), and Measure (CPCS), Short Form-36 Bodily Pain Scale (SF-36 BPS), and Measure
of Intermittent and Constant Osteourthritis Pain (ICOAP.Anhirims Cane of Intermittent and Constant Osteourt
Res. 2011;63(Suppl 11)S200-S252

22. Vasooncelos $\mathrm{T}$, Hall A, Viana R. The influence of inepiratory muscle training on lung function in female baskethell plyyers - a randomized controlled trial. Pario Rsamed J. 2017:2(3):86-89.

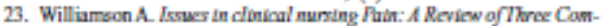
monly Lised Fuin Rä̈rg Scalo. Available fromr https///onlinelibrary. wileycormidoi/pdf. Accessed September 15, 2018.

24. Feverstein M, Beattie P. Bicbehavioral factors affecting pain and disability in low back pain: mechanisms and assessment. Pings Ther. $1995 ; 75: 267-280$

25. Dellve L, AHlstrom L, Jonsson A, et al. Myofeedhack training and intensive muscular strength training bo decrease pain and improve work ability among female wodkers on long-term sick leave with neck pint a randomized controlled trial. Int Arch Ocaup Ervimn Healif. $2011 ; 84(3): 335-346$.

26. Langevin HM, Shermen KJ. Pathophysiological model for chronic low hack pain integrating connective tissue and nervous system mechunisms. Med Hypotheses. 2007;68(1):74-80.

27. Bonica JI. Manzgement of myofascial pain syndromes in general practice. J Am Med Assoc. 1957;164(7):732

8. Akbari A, Khorashadizadeh S, Abdi G. The Effect of Motor Control Exercise versus General Exercise on Lumbar Local Stabilizing Muscles Thickness: Randomized Controlled Trial of Patients with Chronic

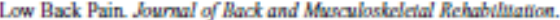
$2008,21(2): 105-112$

29. Lima PO de P, de Oliveira RR, de Moun Filho AG, Raposo MCF, Costo LOP, Laurentino GEC. Recroducibility of the pressure biofsedtuck unitin measering transverses abdominis muscle activity in patients with chronic nosespecific low back pain. J Rodjyw Mor Thar. 2012;16(2)251-257.

30. Storheim K, Be K, Pederstad O, Jahnsen R. Intra-tester reproducibility of pressere biofeedhack in measerement of transversus abdominis function. Physiaher Res int. 2002; 7(4):279-249.

31. Rasouli O, Arab AM, Amiri M, Jabernadeh S. Ultrasund measurement of deep abdominal mascle activity in sitting positions with different stality levels in shiests with ad without chronic low hack pain. Man Ther 2011;16(4):388-393.

32. Hodqes PW. Is there a role for transversus abdominis in lumbo-pelvic stability? Man Ther. 1999-4(2):74-86. 
33. Moseley GL., Hodges PW, Gindevia SC. Decp and Superficial Phers of

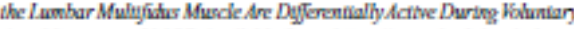
Arm Mowements. Vol 27. Available from https:/ 'ww wbodyinmind.arg' wp-content/uploads/Mosel ey-et-21-2002-Spine-DM-SM-L.M-2rmmovementpaf. Accessed September 17,2018.

34. Kolar P, Neuwirth 1 , Sand 1 , et al. Analysis of diaphragm movement dar ing tidal breathing and during its activation while breath holding using MRI synchronized with spirometry. Finswbl Res. 2009;58(3):383-392.

35. Kolat P, Sulc $\perp$, Kyncl M, et al. Postural function of the diaphragm in persons with and without chronic low back pain. J Onthop Sports Phys Ther. 2012;42(4) -352-362

36. Dalger E, Bilgin S, Bulut E, et al. The effect of stabilization exercives on daphingmm muscle thickness and movement in women with low back pain. J Rack Musculostedet Rehubl.L 2018;31(2):323-329.

37. Macintosh JE, Bogduk N. The biomechanics of the lumber multifaus. Clin Bsamech. 1986:1(4):205-213

38. LiKW, Wang CW, Yu R. Modeling of predictive musculur strength for sustained one-handed carrying task. Wort. 2015;52(4):911-919.

39. Kim E, Lee H. The effects of deep abdominal mascle strengthening exercises on respiratury function and humbar stability. $J$ Phys Ther S2013:25(6):663-665.

40. Hodges P, Kaigle HolmA, Holm S. Intervertebral stiffiness of the spine is increased by evoled contraction of transversus abdominis and the diaphragm. Spine VivoPoncineStudies, editor. Vol. 28(23). Phila P $1976 ; 200325942601$.

41. Cholewicki J, Ivancic PC, Radebold A. Can increased intra-abdominal pressure in humans be decoupled from trunk muscle co-contraction during steady state isometric exertions? Evr J Appl Physsol. 2002;87(2):127-133.
42 Jansens L, Brumbane S, Mcoonnell AK, Hermans G, Troosters T, GayanRamirez G. Greater diaptragm fatigability in individals with recurrent low back pain. Rerpir Phosiol Nawabul. 2013;188(2):119-123.

43. Rezhallah SE, Abd EL-Hady AA. Hamid A. Botens FE. Sonoynuphic Response of Diaphugamuts Froursian to Throhold inspinutory Musde Inatner in Eldeny. Vol 85; 2017. Avilable from: wuw.medicaljoumalofcairouniversity.net. Accessed September 16, 2018.

44. Haytham HM, Arz AE, ES M. NEG. Response of Disphragmatic Excursion to Inspinatory Muscle Trainer Post Thoracotomy. Int J Med Hoal Sect. 2016;10(1)<15-18.

45. Caron Q, Fontanari P, Cremieur I Joulia F. Effects of ventilation on body sway during human standing. Nawesct Lett. 2004;366(1) p6-9.

46. Kucryzaki M, Wieloch $M$. Effects of accelerated breathing on postural stability. Hum Mov. 2009;9(2):107-110.

47. LewitK. Relation of faulty respintion to posture, with clinical implicafions. JAm Orieopath Assac. 1980;79(B):525-529.

48. Hodpes PW, Gurfinkel VS, Brumagne S, Smith TC, Cordo PC. Coexistence of stability and mobility in postural control: evidence from postural compensation for respintion. Exp Bratn Res. 2002;144(3): 293-302.

49. Rankin G, Stokes M, Newham DJ Abdominal muscle size and symmetry in normal subjects. Muscle Nene. 2006;34:3):320-326.

50. Harper CI, Shahgholi L, Cieslak K, Hellyer NJ, Strommen IA, Boon AI Variability in diuphragm motion during normal breathing. 2ssessed with B-mode ulinsound $J$ Orthop Sport Phys Ther. 2013;43(12): 927-931.

51. Kiesel KB, Uhl TL, Underwood FB, Rodd DW, Nitz Al Measurement of lumbar multifidus mascle contraction with rehabilitative ulinasound imaging. Man Ther. 2007;12(2):161-166. 


\section{Supplementary material}

Details of the complex training program

The complex training can be divided into three parts: warmup, main part, and cool-down sections.

1. Warm-up: The training started with a 10 minutes warm-up section. The warm-up consisted of breathing exercises and dynamic exercises for all joints and muscles in standing position.

2. Main part: The training method was a circuit training with five sections and with 3 minutes of exercising in one section, altogether in 40 minutes duration. There were 1 minute breaks between the sections while the participants took their places at the next section.

i. Strengthening exercises of the hip muscles: combined static and dynamic strengthening of the hip muscles ii. Balancing exercise: static balance exercises (holding a position) on an unstable training tool in vertical posture (standing, kneeling)

iii. Strengthening exercises of the extensor muscles of the trunk: combined static and dynamic strengthening of extensors using limb activities with dynamic resistance

iv. Strengthening exercise of the abdominal muscles: combined static and dynamic strengthening of abdominal muscles using limb activities with dynamic resistance

v. Balancing exercise: dynamic reactive balance exercises: walking on unstable surfaces.

3. Cool down: The training ended with a cool-down section of 10 minutes duration. This part of the training consisted of light aerobic, stretching, and breathing exercises. 